\title{
A APLICABILIDADE DO SEGURO DE RESPONSABILIDADE CIVIL DE ADMINISTRADORES E DIRETORES NO ÂMBITO DA ADMINISTRAÇÃO DAS COMPANHIAS
}

\begin{abstract}
Dissertação apresentada ao Departamento de Direito Comercial da Faculdade de Direito da Universidade de São Paulo, como requisito parcial para a obtenção do título de Mestre em Direito, sob orientação da Profa. Dra. Priscila Maria Pereira Corrêa da Fonseca.
\end{abstract}

FACULDADE DE DIREITO DA UNIVERSIDADE DE SÃO PAULO São Paulo 


\section{AGRADECIMENTOS}

Aos meus pais, Antonio e Ana Maria, a quem devo não só o gosto pelo conhecimento e pelas letras, mas uma imensa gratidão pelo incentivo e carinho essenciais à realização deste trabalho.

Ao Matheus, meu irmão, pelo suporte e vibração a cada conquista da minha trajetória acadêmica.

Aos queridos amigos, Patrícia e Luiz, pelo apoio incondicional, pelas revisões de texto e pela compreensão nas minhas ausências.

Ao Departamento de Direito Comercial da Faculdade de Direito da Universidade de São Paulo, pela oportunidade de desenvolver este trabalho.

À professora Priscila Maria Pereira Corrêa da Fonseca, pela confiança e orientação, pelo acompanhamento desde o início deste projeto e pelo valioso conhecimento compartilhado.

Aos professores Paulo F. C. S. de Toledo e Antonio Martin, por suas considerações sobre este trabalho no exame de qualificação.

Ao Pinheiro Neto Advogados, em especial ao Bruno Balduccini e ao José Luiz Homem de Mello, pelo papel fundamental no meu desenvolvimento profissional, e ao Diógenes Gonçalves e ao Thomaz Kastrup, pelos conselhos e sugestões.

Às seguradoras ACE Seguradora S.A., Chubb do Brasil Cia de Seguros e Zurich Brasil Seguros S.A., pela atenção e pelas informações disponibilizadas para as pesquisas relacionadas a este trabalho. 


\section{RESUMO}

Acompanhando o desenvolvimento do mercado de capitais brasileiro, a procura pelo seguro de responsabilidade civil de diretores e administradores, cujo principal objetivo é ressarcir as perdas pecuniárias que os administradores venham a sofrer em virtude de reclamações de terceiros, cresceu significativamente nos últimos anos. Se de um lado este seguro mostra-se um importante instrumento de proteção aos administradores diligentes que porventura tenham seu patrimônio afetado para reparação de danos a terceiros prejudicados por seus atos, de outro, ele poderia servir de incentivo aos maus gestores que, amparados pelo seguro, negligenciariam seus deveres e obrigações enquanto administradores, gerando o chamado risco moral (moral hazard). Mediante a análise de hipóteses em que se discute a aplicação do seguro no âmbito da administração das companhias, este trabalho propõe-se a examinar de que forma os múltiplos efeitos resultantes da aplicabilidade ou o do afastamento da aplicabilidade do seguro afetam o comportamento dos administradores, bem como debater a admissibilidade do seguro no direito brasileiro, vis-à-vis os questionamentos relativos às situações que colocam em xeque a viabilidade da cobertura securitária.

PALAVRAS-CHAVE: Seguro, Responsabilidade Civil, $D \& O$, Administradores, Risco, Moral Hazard, Deveres. 


\begin{abstract}
Following the development of the Brazilian capital market, the demand for the directors' and officers' liability insurance ("D\&O Insurance") - whose main purpose is to indemnify pecuniary losses incurred by managers as a result of third-party complaints against them grew considerably in the past few years. On the one hand, the D\&O Insurance appears as an important instrument for protection of diligent managers who happen to have their assets affected in order to indemnify damages deriving from their acts; on the other hand, this type of insurance could be seen as an incentive for bad managers, who could neglect their duties and obligations in their capacity as officers based on the protection afforded by the D\&O Insurance, therefore increasing the so-named moral hazard. By analyzing the hypothesis in which the applicability of the insurance is questionable, this paper intends to examine how the multiple effects arising from the applicability or the inapplicability of the D\&O Insurance affect the managers' behavior, as well as to discuss the admissibility of this type of insurance by the Brazilian law, vis-à-vis the situations where the feasibility of the insurance coverage is questionable.
\end{abstract}

KEYWORDS: Insurance, Civil Liability, D\&O, Managers, Risk, Moral Hazard, Duties. 


\section{SUMÁRIO}

1. INTRODUÇÃ

2. RESPONSABILIDADE DOS ADMINISTRADORES: ASPECTOS FUNDAMENTAIS ASSOCIADOS AO SEGURO DE RESPONSABILIDADE CIVIL......... 16

2.1. Formas de Responsabilização dos Administradores.................................... 16

2.2. Responsabilidade Penal................................................................................. 19

2.3. Responsabilidade Civil............................................................................. 21

2.3.1. Considerações sobre a Responsabilidade Civil no Brasil................ $\quad 21$

2.3.2. A Responsabilidade Civil, o Exercício da Administração e a Consagração do Seguro de Responsabilidade Civil...................................... 23

2.3.3. Função da Responsabilidade Civil dos Administradores................. 26

2.4. Responsabilidade Administrativa............................................................ 27

3. HISTÓRICO, CARACTERÍSTICAS, FORMALIZAÇÃO E FINALIDADE DAS OPERAÇÕES DE SEGURO............................................................................................... 29

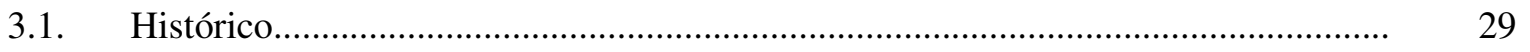

3.2. Aspectos Jurídicos e Extrajurídicos das Operações de Seguro..................................... 31

3.3. Contrato de Seguro.......................................................................................... 33

3.3.1. Natureza do Contrato e Importância da Técnica Contratual.......................... 33

3.3.2. Elementos do Contrato.............................................................................. 37

3.3.2.1. Interesse Legítimo................................................................... 37

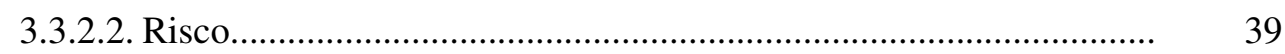

3.3.2.3. Prêmio e Garantia................................................................................

4. SEGURO DE RESPONSABILIDADE CIVIL_................................................... 42

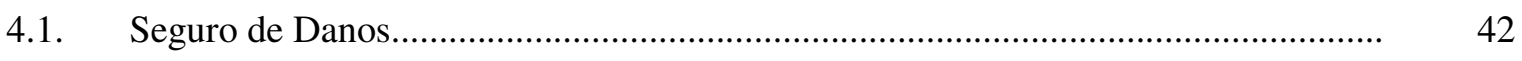

4.2. Particularidades do Seguro de Responsabilidade..................................................... 43

4.2.1. Da Garantia e Seus Limites.......................................................................... 43

4.2.2. Do Interesse Segurável........................................................................... 45

4.2.3. Do Momento do Sinistro................................................................................ 46

4.2.4. Da Delimitação Temporal................................................................................ 48 
5. SEGURO DE RESPONSABILIDADE CIVIL DE ADMINISTRADORES......... 52

5.1. Histórico....................................................................................................... 52

5.2. Regulamentação............................................................................................... 54

5.3. Características do Seguro................................................................................ 55

5.3.1. Tomador e Beneficiário................................................................................ 55

5.3.2. Garantias e Cobertura................................................................................ 56

5.3.3. Seleção de Riscos...................................................................................... 58

5.4. Apuração da Responsabilidade Civil e Administrativa................................................ 61

5.4.1. Deveres do Administrador.............................................................................. 61

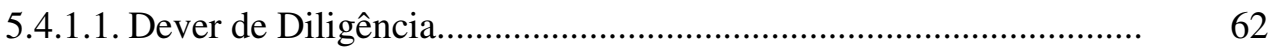

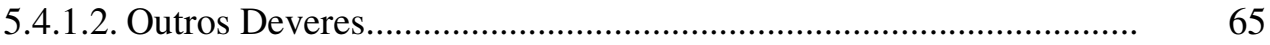

5.4.2. Apuração da Responsabilidade Civil............................................................ 66

5.4.3. Apuração da Responsabilidade Administrativa........................................... $\quad 70$

5.4.3.1. O Procedimento Administrativo........................................................... $\quad 70$

5.4.3.2. As Penalidades Impostas pela CVM............................................ 72

5.4.3.3. Termo de Compromisso...................................................................... 73

5.4.4. Cobertura Securitária e Apuração da Responsabilidade................................. 75

5.5. Relação entre a Responsabilidade Pessoal e a Cobertura das Apólices de Seguro de Responsabilidade Civil........................................................................................ 77

5.5.1. Ato do Administrador sob a Perspectiva da Responsabilidade Civil e

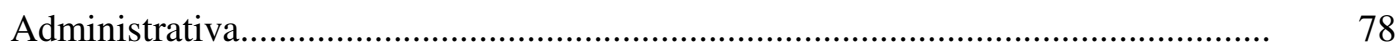

5.5.2. Ato do Administrador sob a Perspectiva Securitária................................... 80

6. A APLICABILIDADE DO SEGURO DE RESPONSABILIDADE CIVIL DE ADMINISTRADORES NO ÂMBITO DA ADMINISTRAÇÃO DAS

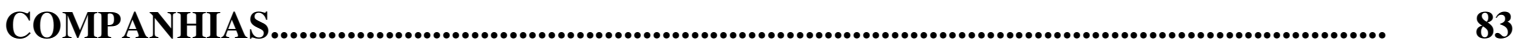

6.1. Aspectos Gerais Relativos à Aplicabilidade do Seguro.............................................. 83

6.1.1. Metodologia Adotada................................................................................... 84

6.1.2. Aplicação do Seguro de Responsabilidade Civil de Administradores no Mercado Brasileiro.............................................................................................. 86

6.2. Análise Circunstanciada da Aplicabilidade do Seguro................................................ 88

6.2.1. Aplicação Imediata............................................................................... 88

6.2.2. Algumas Restrições e Limites à Aplicabilidade do Seguro........................... 89

6.2.2.1. Multas e Penalidades Civis.............................................................. 90 
6.2.2.2. Momento da Notificação: Quando e o que notificar?.......

6.2.2.3. Solidariedade.

6.2.2.4. Reclamações envolvendo Disputas entre Segurados, entre

Segurado e Companhia e entre Segurado e Acionista.....

6.2.2.5. Outras Limitações.

6.2.3. Afastamento da Aplicabilidade do Seguro

6.2.3.1. Exclusões de Cobertura

6.2.3.2. Perda do Direito à Indenização e Rescisão.

6.2.3.3. O exemplo do Banco Santos S.A...

6.3. Admissibilidade do Seguro de Responsabilidade Civil de Administradores.

6.3.1. Função Social

6.3.2. O Papel do Seguro na Governança Corporativa.

6.3.3. Considerações Sobre o Risco Moral (Moral Hazard) e o Seguro de Responsabilidade Civil de Administradores.

6.3.4. Admissibilidade do Seguro de Responsabilidade Civil de Administradores no Direito Brasileiro

7. CONCLUSÃO

8. REFERÊNCIAS BIBLIOGRÁFICAS.

9. ANEXO I - Parecer da Procuradoria de Assuntos Societários e Regimes Especiais da Superintendência de Seguros Privados. 


\section{INTRODUÇÃO}

O desenvolvimento do mercado de capitais nas economias em florescimento e, especialmente no Brasil, foi impulsionado por duas potentes forças: uma de caráter econômico, outra de cunho jurídico. A força econômica, beneficiada pela elevada liquidez do mercado financeiro internacional (mercado em que abundam participantes ávidos por oportunidades em economias em desenvolvimento), teve seu potencial reforçado pela estabilidade da moeda nacional e condições macroeconômicas relativamente estáveis, com a contenção da alta da inflação e das taxas de juros.

O salto proporcionado pela força econômica e a consolidação da presença brasileira no mercado internacional contaram com uma intensa pressão dos investidores para que o País redesenhasse as normas que regem as transações cursadas neste mercado visando a reduzir as discrepâncias no tratamento dispensado a acionistas, administradores e companhias, uma vez que tais transações se processam em um ambiente marcado pelo entrelaçamento de regras jurídicas e mercadológicas.

Em resposta a estas pressões, foi acionada a mola jurídica que, a exemplo das recentes alterações à Lei 6.404 de 15 de dezembro de 1976 - a Lei das Sociedades por Ações ("LSA") e da implementação dos segmentos especiais de governança corporativa nas bolsas de valores, introduziu no ordenamento, dispositivos destinados preponderantemente à proteção das minorias e dos investidores e, consequentemente, ao atendimento dos anseios dos consumidores e à proteção do mercado como um todo.

À medida que este cenário foi sendo delineado, verificou-se a necessidade de uma maior interação entre o Estado, na qualidade de regulador da responsabilidade civil, e os entes privados, como destinatários desta regulação. A participação dos agentes de mercado tanto nas audiências públicas promovidas pela Comissão de Valores Mobiliários (“CVM") para discussão de novas instruções normativas, como na implementação do segmento do novo mercado, resultado de esforços de investidores e da atual BM\&FBovespa, são um bom exemplo do fortalecimento do modelo de atuação conjunta do Estado e da iniciativa privada. 
Assim, acompanhando a tendência de proteção intentada pelas inovações no campo normativo, os agentes privados contribuíram com o aprimoramento de meios alternativos de proteção, tais como os seguros de responsabilidade civil de diretores e administradores.

Resumidamente, este seguro tem por objetivo resguardar o patrimônio dos administradores das despesas envolvidas na defesa e reparação de danos a terceiros decorrentes de sua responsabilização pessoal por causa de ato praticado no exercício de suas atribuições.

De utilização um tanto tímida até 2008 , o valor dos prêmios praticamente duplicou de 2009 a 2011 (provavelmente como um reflexo da crise global no início do período), como demonstra o quadro a seguir:

\begin{tabular}{|c|c|c|c|}
\hline Ano & $\begin{array}{c}\text { Prêmio Direto } \\
(\mathbf{R} \$)\end{array}$ & $\begin{array}{c}\text { Sinistro de Seguros } \\
(\mathbf{R} \$)\end{array}$ & Sinistralidade (\%) \\
\hline 2008 & 93.082 .781 & 8.919 .242 & 0,12 \\
\hline 2009 & 94.682 .118 & 11.003 .537 & 0,19 \\
\hline 2010 & 147.801 .791 & 63.251 .019 & 0,50 \\
\hline 2011 & 171.538 .619 & 8.059 .606 & 0,09 \\
\hline
\end{tabular}

Fonte: SUSEP (http://www2.susep.gov.br/menuestatistica/SES/premiosesinistros.aspx?id=54)

Como se nota, o índice de sinistralidade não acompanhou o crescimento dos prêmios. Confira-se a representação gráfica:

Evolução da Sinistralidade
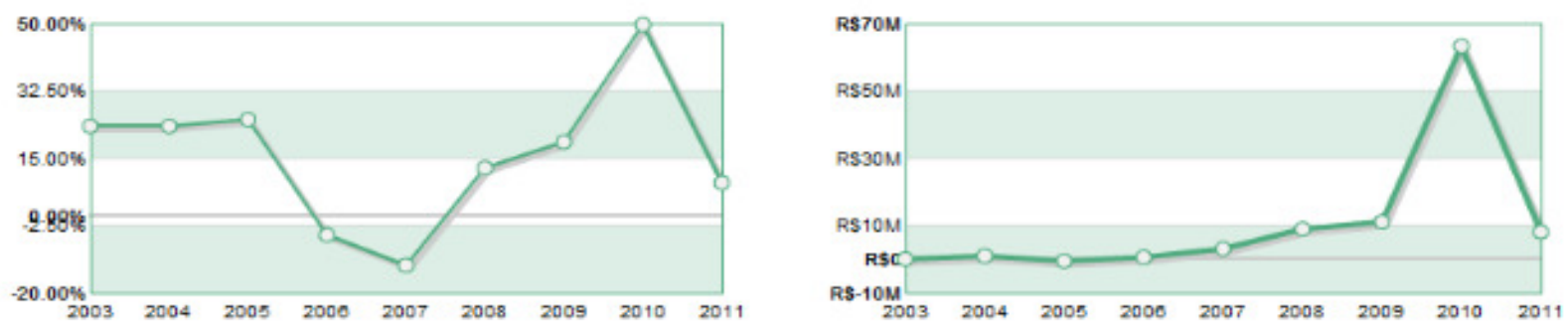

Fonte: SUSEP (http://www2.susep.gov.br/menuestatistica/SES/premiosesinistros.aspx?id=54)

O peculiar comportamento deste seguro nos períodos de crise e no período que o sucede, associado ao crescimento na sua procura e às recentes discussões acerca de sua 
aplicação no âmbito do mercado de capitais motivou a escolha deste seguro como objeto de análise deste trabalho ${ }^{1}$.

Este estudo examinará a aplicabilidade deste seguro no âmbito da administração das companhias, visando a apreciar sua conveniência não só para os administradores, como para os investidores, para o Estado e para o mercado de capitais como um todo.

Para tanto, o trabalho será dividido em quatro partes: (i) breve análise das responsabilidades do administrador; (ii) estudo do seguro de responsabilidade civil dos administradores, precedido de uma sucinta abordagem das operações de seguro e do funcionamento dos seguros de responsabilidade civil; (iii) discussão da aplicabilidade do seguro de responsabilidade civil dos administradores, vis-à-vis os aspectos societários e securitários relativos à conduta do administrador; e (iv) debate acerca da admissibilidade deste seguro no âmbito do mercado de capitais.

Especificamente com relação à terceira parte, nota-se que o exame da aplicabilidade não se faz em abstrato, sendo realizado somente quando uma situação concreta impõe a discussão sobre a possibilidade de um determinado ato ou fato do segurado ser passível de cobertura securitária.

Conquanto seja inviável esgotar todas as situações fáticas que permitam a apreciação da aplicabilidade do seguro - haja vista a impossibilidade de se criar um rol taxativo de casos concretos em que este questionamento se apresentaria - este trabalho analisará as situações que, de acordo com levantamento realizado pelas seguradoras brasileiras ACE Seguradora S.A. (“ACE")², Chubb do Brasil Cia de Seguros ("CHUBB”)³

\footnotetext{
${ }^{1}$ Ernesto Tzirulnik bem observa que, nos períodos de crise, o seguro ganha ainda mais importância: "Neste contexto, a atividade securitária tem sua importância multiplicada: as garantias contra eventos desestabilizadores passaram a ser uma garantia das coletividades contra as consequências ainda desconhecidas, mas já temidas, do próprio processo de globalização, do qual muitas vezes atônitos ouvimos falar, sem ideia das formas de defesa de que dispomos." TZIRULNIK, Ernesto e OCTAVIANI, Alessandro. Seguro e Fraude - As Provas. Artigo para o Instituto Brasileiro de Direito de Seguros, p. 2. Disponível em $<$ http://www.ibds.com.br/artigos/SeguroEFraude-AsProvas.pdf>. Acesso em 15.10.2012.

${ }^{2}$ Conforme entrevista concedida por Leandro Martinez, diretor de linhas financeiras da ACE Seguradora S.A. em 28.9.2012.

${ }^{3}$ Conforme entrevista concedida por Priscilla de Souza, gerente de linhas financeiras da Chubb do Brasil Cia de Seguros em 29.3.2012 e por Silvia Amaral, gerente de sinistros de responsabilidade civil da Chubb do Brasil Cia de Seguros em 26.9.2012.
} 
e Zurich Brasil Seguros S.A. ("ZURICH”)", tem sido as mais recorrentes no mercado securitário. Trata-se de três das cinco seguradoras brasileiras que oferecem este seguro no Brasil há mais tempo e que mais faturaram neste ramo nos últimos anos ${ }^{5}$.

Para fins didáticos, as hipóteses em que a cobertura securitária é demandada pelo segurado serão separadas em três grupos, a saber (i) hipóteses em que a aplicabilidade é, a princípio, indiscutível; (ii) hipóteses em que a aplicabilidade é questionável; e (iii) hipóteses em que a aplicabilidade do seguro é afastada.

A sistematização das hipóteses conforme o modelo descrito acima foi adotada para permitir a verificação da pertinência da indenização securitária quando do acionamento do seguro em face das situações fáticas (no âmbito da administração das companhias) que ensejaram a busca por cobertura securitária.

A análise da aplicabilidade do seguro é, pois, imprescindível para se discutir a admissibilidade do seguro estudado no âmbito do mercado de capitais brasileiro, bem como para avaliar se eventualmente os administradores não poderiam encará-lo como salvo conduto ou mesmo incentivo para se aventurarem em operações mais ousadas ou para simplesmente furtarem-se aos deveres que devem pautar seu comportamento, tópicos a serem abordados na quarta e última parte.

Como observado anteriormente, por conta da amplitude da aplicabilidade seguro, muito se discute sobre a aceitação deste seguro à luz do direito brasileiro. A reflexão ora proposta, por meio da contraposição entre as vantagens e desvantagens que o seguro representa, sugere que o seguro em discussão é não só admissível, com também de grande importância para o mercado de capitais.

Previamente à abordagem da discussão central de que tratará este trabalho, cabem algumas importantes observações no que diz respeito à nomenclatura adotada.

\footnotetext{
${ }^{4}$ Conforme entrevista concedida por Fernando Saccon, gerente de linhas financeiras da Zurich Brasil Seguros S.A. em 25.9.2012.

${ }^{5}$ Conforme levantamento do valor global prêmios relativos a seguro de responsabilidade civil de administradores recebidos por todas as seguradoras brasileiras que atuam no ramo no período de janeiro de 2002 a julho de 2012 mediante consulta a site da SUSEP $<$ http://www2.susep.gov.br/menuestatistica/SES/premiosesinistros.aspx?id=54>. Acesso em 15.10.2012. Vide informações adicionais sobre a metodologia adotada no Capítulo VI (6.1.1).
} 
Originalmente concebido em Londres, o seguro de responsabilidade civil de administradores foi designado Directors and Officers Insurance, mais conhecido na forma abreviada $D \& O$ Insurance. Quando importado pelo direito brasileiro, o instituto foi batizado de "Seguro de Responsabilidade Civil de Diretores e Administradores".

Embora seja denominado "seguro de responsabilidade civil", é sabido que responsabilidades dos administradores transcendem a esfera civil (e.g., responsabilidade administrativa, criminal, tributária, dentre outras). Isto não impede, com algumas exceções, que a cobertura do seguro alcance as diversas responsabilidades em questão. Estas outras responsabilidades geralmente são incluídas no âmbito da proteção da apólice de seguro de responsabilidade civil mediante a contratação de extensões específicas de cobertura.

Ainda sobre a terminologia adotada pelo direito pátrio, vale ressaltar que a tradução literal do termo Directors (que, em matéria de direito societário brasileiro, correspondem aos membros do conselho de administração), sugere que somente poderiam ser segurados os gestores ocupantes de cargos da diretoria e do conselho de administração ${ }^{6}$.

O mercado local deste seguro, entretanto, adota uma interpretação mais extensiva, incluindo como beneficiários do seguro os membros do conselho fiscal, os membros de órgãos técnicos e consultivos constituídos conforme o estatuto social.

Por não haver regulamentação específica que determine um rol taxativo de segurados, algumas seguradoras adotam um critério ainda mais amplo, permitindo que figurem como beneficiários todas as pessoas que de alguma forma tenham ingerência sobre os negócios sociais, que estejam envolvidas com a tomada de decisão pela sociedade e/ou que realizem representação de fato da sociedade tomadora e de suas subsidiárias, motivo pelo qual poderiam ser demandadas por terceiros.

Destarte, os beneficiários do seguro de responsabilidade civil de administradores podem, portanto, abranger diretores não estatutários, gerentes, supervisores, procuradores e empregados que desempenhem funções gerenciais.

\footnotetext{
${ }^{6}$ Art. 138 da LSA - A administração da companhia competirá, conforme dispuser o estatuto, ao conselho de administração e à diretoria, ou somente à diretoria.
} 
Em que pese ser imprescindível a análise da responsabilidade civil para o debate das questões aqui colocadas, empregar-se-á o termo "administrador" (aqui compreendidos os diretores, membros do conselho de administração e membros de quaisquer outros órgãos estatutários que possuam funções técnicas ou de aconselhamento dos administradores, conforme o artigo 143 da LSA) como desígnio único para os beneficiários das apólices de seguro de responsabilidade civil de administradores.

Os possíveis tomadores deste seguro podem ser sociedades limitadas, sociedades anônimas e fundações, mas, considerando que a abordagem deste estudo volta-se ao mercado de capitais, os tomadores ficarão restritos às sociedades anônimas, aqui tratadas por "companhias"”.

No que tange ao tomador do seguro de responsabilidade civil de administradores, em regra, a contratante deste seguro é a companhia ${ }^{8}$ cuja gestão compete aos administradores beneficiários do seguro contratado por tal entidade, incumbindo a ela o pagamento do prêmio, a manutenção e o gerenciamento da apólice.

Inclusive, mesmo sendo contratado em benefício de pessoas físicas, há casos em que a seguradora também se obriga a reembolsar a companhia, caso esta tenha adiantado recursos para defesa do segurado. Em casos especiais, como cobertura para reclamações no âmbito do mercado de capitais, o seguro de responsabilidade civil de administradores pode contemplar ainda cobertura para danos sofridos pela própria companhia.

As características descritas acima explicam, em parte, porque o seguro de responsabilidade civil de administradores tornou-se tão atraente nos últimos anos. $\mathrm{O}$ primeiro grande apelo deste seguro está na multiplicidade de interesses que ele alcança. Seus beneficiários imediatos, os administradores, têm particular interesse no seguro, pois

\footnotetext{
${ }^{7}$ Embora, em sua maioria, as instituições financeiras sejam constituídas sob a forma de sociedades anônimas, o estudo aqui proposto limitar-se-á às questões envolvendo as companhias não-financeiras. As responsabilidades dos dirigentes de instituições financeiras possuem regras específicas que transcendem a LSA, sendo regida por leis próprias e normativos expedidos pelo Conselho Monetário Nacional e pelo Banco Central do Brasil. Ademais, os aspectos relativos à responsabilidade administrativa dos administradores (que, nas companhias não-financeiras, é apurada pela CVM) teriam que ser analisados também à luz da atuação do Banco Central do Brasil, o que tornaria esta pesquisa demasiadamente abrangente.

${ }^{8}$ Já existem no Brasil as apólices de seguro de responsabilidade de administradores que podem ser contratadas diretamente pelo administrado, como o "seguro D\&O One" oferecido pela ZURICH. Contudo, conforme informado por esta seguradora, seu uso ainda é pouco difundido no Brasil, sobretudo pelo elevado custo do prêmio, que por vezes tornam o seguro desinteressante para o administrador.
} 
ele evita que seu patrimônio pessoal seja atacado para pagamento dos custos de defesa e eventuais condenações pecuniárias que venha a ser obrigado a pagar.

O seguro agrada também aos investidores, aos demais terceiros com os quais a companhia se relaciona e até mesmo à própria companhia na medida em que qualquer um deles pode acionar os administradores de uma companhia e, quando titulares de direito a indenização devida por administrador, não ficam à mercê da solvência deste último ${ }^{9}$.

Por fim, este seguro aproveita ainda ao Estado, beneficiado tanto diretamente, (quando uma autoridade regulatória instaura um procedimento contra os administradores, sendo destinatária de valores resultantes de eventuais condenações), como indiretamente, uma vez que a noção de proteção patrimonial experimentada pelos administradores e pelos investidores proporciona maior confiabilidade ao sistema. A segurança conferida ao sistema cria um ambiente propício ao crescimento do mercado de capitais, ambiente este de indiscutível importância para o desenvolvimento do país ${ }^{10}$.

O seguro de responsabilidade civil de administradores, entretanto, pode nem sempre atender aos anseios de seus destinatários, pois certos fatores (majoritariamente associados à conduta do administrador) limitam ou até mesmo impedem a aplicabilidade do seguro.

Em regra, o seguro é aplicável quando os administradores (i) incorrem em custos de defesa em processos administrativos e/ou judiciais relacionados a ato regular de gestão; e (ii) são obrigados a pagar indenizações decorrentes de atos culposos (excetuada a culpa grave) pelos quais venham a ser responsabilizados, pessoal ou solidariamente.

\footnotetext{
${ }^{9}$ Neste sentido, vide posicionamento de Ernesto Tzirulnik: "A questão deve ser abordada sob o duplo aspecto do interesse segurado: por um lado, o seguro de responsabilidade civil visando evitar prejuízos ao patrimônio do segurado, permitindo que esteja apto a honrar com as possíveis consequências de sua responsabilidade civil sem comprometer a atividade que desenvolve; de outra banda, visando a garantir que o terceiro lesado seja indenizado, sem que a reparação esteja sujeita às dificuldades financeiras do segurado ou mesmo sua insolvência.”. TZIRULNIK, Ernesto. O Futuro do Seguro de Responsabilidade Civil. In Doutrinas Essenciais - Responsabilidade Civil: Direito das Obrigações e Direito Negocial (org. Nelson Nery Junior e Rosa Maria de Andrade Nery), $2^{\mathrm{a}}$ ed., São Paulo: Revista dos Tribunais, 2010, p. 724.

${ }^{10}$ Sobre a importância do mercado de valores mobiliários para o desenvolvimento econômico e social do país, Arnoldo Wald observa que "além do seu objetivo de lucro, a sociedade anônima atende aos interesses gerais da comunidade, mantendo e criando empregos, utilizando e desenvolvendo poupança, satisfazendo as necessidades dos consumidores." WALD, Arnoldo. Interesses societários e extra-societários na administração das sociedades anônimas: a perspectiva brasileira, in Revista de Direito Mercantil, $\mathrm{n}^{\circ} 55$, jun/set 1984, p. 13.
} 
A experiência prática mostra, contudo, que a aplicabilidade do seguro pode ser limitada ou até mesmo completamente afastada, como no caso de vícios no ato da contratação do seguro, desvios de conduta do administrador, impossibilidade de assegurar determinados atos ou fatos por imposição da lei ou de autoridades regulatórias, dentre outras hipóteses.

A prática demonstra ainda que a aplicabilidade do seguro de responsabilidade civil de administradores caminha sempre em linha com a conduta do administrador. E, neste ponto, entenda-se por conduta não somente seu comportamento no desempenho de suas funções de gestão, mas também a forma como se comporta diante do seguro de responsabilidade civil (e.g., se no momento da contratação do seguro faz declarações verdadeiras, se presta ou omite todas as informações de seu conhecimento, se comunica à seguradora ato ou fato capaz de agravar o risco, dentre outras hipóteses).

É neste contexto que se insere a importância do estudo da aplicabilidade seguro de responsabilidade civil de administradores. A apreciação das situações em que a aplicabilidade do seguro é certa, em que é discutível e em que é repelida (seja mediante negativa de cobertura, seja mediante rescisão do contrato de seguro) fornece elementos para avaliar as vantagens e desvantagens do seguro, bem como para discutir sua admissibilidade no direito brasileiro. 


\section{RESPONSABILIDADE DOS ADMINISTRADORES: ASPECTOS FUNDAMENTAIS ASSOCIADOS AO SEGURO DE RESPONSABILIDADE CIVIL}

Como dito anteriormente, não consiste objeto desta pesquisa o exame aprofundado da responsabilidade dos administradores, mas, por se tratar de um assunto incidental de considerável relevância ao tema proposto, faz-se necessário abordar alguns aspectos fundamentais da responsabilidade relacionados ao estudo do seguro em questão.

\subsection{FORMAS DE RESPONSABILIZAÇÃO DOS ADMINISTRADORES}

No Brasil, a regra geral prevista na $\operatorname{LSA}^{11}$ acerca da responsabilidade civil dos administradores determina que os atos por eles praticados em nome das companhias que administram não os obrigam pessoalmente ${ }^{12}$, exceto se (i) praticados com dolo ou culpa grave; e (ii) violarem a lei ou as disposições do estatuto social.

Embora a responsabilização pessoal esteja intrinsecamente ligada à culpabilidade e à subjetividade da conduta dos administradores no exercício da gestão, havendo violação da lei ou do estatuto, o administrador responderá independente de culpa, conforme ensina José Alexandre Tavares Guerreiro:

Em tal caso, as consequências reparatórias imputadas ao administrador prescindem da existência de culpa no seu proceder, bastando que se evidencie a causação de prejuízos, que à sociedade, quer aos acionistas, quer ainda a terceiros ${ }^{13}$.

\footnotetext{
${ }^{11}$ Art. 158 - O administrador não é pessoalmente responsável pelas obrigações que contrair em nome da sociedade e em virtude de ato regular de gestão; responde, porém, civilmente, pelos prejuízos que causar, quando proceder: I - dentro de suas atribuições ou poderes, com culpa ou dolo; II - com violação da lei ou do estatuto.

12،Atuando como órgão da pessoa jurídica, nada mais faz a pessoa física do administrador do que realizar a vontade do ente coletivo. No relacionamento com terceiros, é a própria sociedade anônima que se obriga, inexistindo, em consequência, qualquer razão capaz de justificar o comprometimento pessoal do administrador e de seu patrimônio particular em virtude dos atos praticados como representante da companhia, ressalvadas as exceções previstas em lei, quer no diploma que rege as sociedades por ações, que na legislação especial." GUERREIRO, José Alexandre Tavares, Responsabilidade dos Administradores de Sociedades Anônimas, in Revista de Direito Mercantil, Industrial, Econômico e Financeiro, ano XX (nova série), no 42, São Paulo: RT, 1981, p. 73. Neste mesmo sentido, vide BULGARELLI, Waldirio. Apontamentos sobre a responsabilidade dos administradores das companhias, in Revista de Direito Mercantil, Industrial, Econômico e Financeiro no 50, abr-jun/1983, p. 87.

${ }^{13}$ GUERREIRO, José Alexandre Tavares, op. cit., p. 77.
} 
Neste sentido, há no ordenamento jurídico brasileiro leis esparsas em diferentes ramos do direito que também regulam questões atinentes à responsabilidade do administrador e que, de certa forma, ampliam as hipóteses em que o administrador responde pessoalmente, como, por exemplo, no âmbito tributário ${ }^{14}$ e ambiental ${ }^{15}$. O mesmo pode acontecer nas esferas trabalhista, previdenciária, consumerista, concorrencial e falimentar, observada a legislação específica atinente a cada uma delas.

Não por outra razão que, conforme mencionado na introdução, não obstante o fato de o seguro ser denominado de responsabilidade civil, a cobertura securitária por ele oferecida costuma abranger também a responsabilidade administrativa e, excepcionalmente, algumas situações de responsabilidade penal.

De todo modo, em qualquer das searas do direito em que se insira a responsabilidade do administrador, os efeitos dela decorrentes desdobram-se basicamente em três esferas: a responsabilidade penal, a civil e a administrativa. Um mesmo ato danoso praticado pelo administrador tem, pois, o condão de acarretar responsabilidade em uma ou mais das três esferas referidas acima. Este capítulo apresentará um panorama das responsabilidades pertencentes a estas três categorias.

Como as responsabilidades que recaem sobre um mesmo ato nem sempre podem ser facilmente identificadas, a doutrina propõe critérios diversos para aferir o tipo de responsabilidade que emana de uma determinada conduta.

Magalhães Noronha ${ }^{16}$ defende a avaliação do grau de lesividade da violação à ordem jurídica, identificando as condutas de maior gravidade com a responsabilização penal e as de menor potencial ofensivo com a responsabilização civil e/ou administrativa.

\footnotetext{
${ }^{14}$ Lei 5.172/66, Art. 135, III - São pessoalmente responsáveis pelos créditos correspondentes a obrigações tributárias resultantes de atos praticados com excesso de poderes ou infração de lei, contrato social ou estatutos: III - os diretores, gerentes ou representantes de pessoas jurídicas de direito privado..

${ }^{15}$ Lei $n^{\circ}$ 6.938/81, Art $3^{\circ}$, IV - Para os fins previstos nesta Lei, entende-se por poluidor, a pessoa física ou jurídica, de direito público ou privado, responsável, direta ou indiretamente, por atividade causadora de degradação ambiental. / Art. 14, § $1^{\circ}$ : Sem obstar a aplicação das penalidades previstas neste artigo, é o poluidor obrigado, independentemente da existência de culpa, a indenizar ou reparar os danos causados ao meio ambiente e a terceiros, afetados por sua atividade.

${ }^{16}$ NORONHA, E. Magalhães. Direito penal, v. 1, 4ª ed., São Paulo: Saraiva, 1967, p. 121.
} 
Os Mazeaud inicialmente sugerem que a distinção entre as responsabilidades deve levar em conta os efeitos, a repercussão da lesão, havendo responsabilidade penal quando o dano atingir a ordem social, a coletividade, e civil quando o dano atingir uma determinada pessoa, fazendo com que seus efeitos sejam sentidos apenas por particulares ${ }^{17}$. Basileu Garcia adota critério similar, propondo que a divisão reside na existência de interesse público ou meramente individual ${ }^{18}$.

José Aguiar Dias, por sua vez, afasta estas distinções, argumentando que toda lesão individual também atinge a ordem social. De modo geral, o autor defende que a diferença reside no fato de que a responsabilização civil implica coação patrimonial, a penal, uma coação pessoal $^{19}$.

Esclarece ainda que a diferença estaria nos objetivos intentados pela responsabilização, buscando-se punição no caso da responsabilidade penal e reparação (indenização, restituição ou declaração de nulidade do ato) no caso responsabilidade civil. Em última análise, esta também foi a conclusão a que chegaram os Mazeaud ${ }^{20}$.

A responsabilidade administrativa, em certa medida, aproxima-se da responsabilidade penal, pois, em regra, a infração a uma norma administrativa traduz-se em sanção pecuniária, restrição de direitos (tais como inabilitação, suspensão do exercício de determinadas atividades, dentre outros) ou ambos.

Em que pese o objeto central deste estudo ser o modo como as condutas do administrador que ensejam sua responsabilização refletem na aplicabilidade do seguro de responsabilidade civil, cada uma destas três esferas será examinada a seguir, focando-se a análise nos atos da administração e na sua repercussão em cada uma delas.

\footnotetext{
${ }^{17}$ MAZEAUD, Henri; MAZEAUD, Léon. Traité théorique et pratique de la responsabilité civile délictuelle et contractuelle. v.3. Paris: Recueil Sirey, 1931. pp. 5-8.

${ }^{18}$ GARCIA, Basileu. Instituições de direito penal, v. 1, t. 1. 4a ed., São Paulo: Max Limonad, 1968, pp. 17-18.

${ }^{19}$ DIAS, José Aguiar, Da responsabilidade Civil, $11^{\mathrm{a}}$ ed., Rio de Janeiro: Renovar, 2006, p. 11.

${ }^{20}$ MAZEAUD, Henri; MAZEAUD, Léon, op. cit., pp. 5-8.
} 


\subsection{RESPONSABILIDADE PENAL}

No direito penal brasileiro, em regra, somente podem ser sujeitos ativos de crimes as pessoas físicas que tiverem, de alguma forma, praticado ou concorrido para a prática delituosa. A responsabilidade penal é subjetiva e personalíssima e somente pode ser atribuída em conformidade com o disposto no artigo $5^{\circ}, \mathrm{XLV}$ da Constituição Federal ${ }^{21}$ e no artigo 29 do Código Penal ${ }^{22}$.

Não se admite tampouco a responsabilidade objetiva da pessoa física, ou seja, a responsabilização penal pressupõe prova da efetiva participação do indivíduo na consecução do crime, não podendo a pena ultrapassar a pessoa do condenado, que responderá pelo crime na medida de sua atuação e de sua culpabilidade.

Destarte, a responsabilidade penal pode recair sobre o administrador que tiver participado da conduta delituosa, quer diretamente, praticando a conduta descrita no tipo penal (crimes comissivos), quer indiretamente, omitindo-se diante de uma conduta delituosa ou deixando de tomar decisões ou medidas que evitariam uma conduta delituosa da qual tinha conhecimento e que poderia ter evitado (crimes omissivos).

No contexto empresarial, estes princípios são fundamentais para evitar que condutas puníveis no âmbito penal impliquem responsabilização dos indivíduos que não participaram nem tinham conhecimento do ilícito. A este respeito, bem observa Hugo de Brito Machado que:

Só quem não tem vivência do mundo empresarial pode supor que no âmbito de uma empresa todos os sócios, ou acionistas, ou mesmo diretores, sabem de tudo o que ali acontece. Muitas vezes pode ocorrer inclusive que um ilícito tributário seja cometido até em detrimento da sociedade, em proveito do próprio autor da conduta ilícita, seja ele simples empregado, ou gerente, ou diretor, ou acionista, mesmo o controlador $^{23}$.

\footnotetext{
${ }^{21}$ Art. $5^{\circ}$, XLV - Nenhuma pena passará da pessoa do condenado, podendo a obrigação de reparar o dano e a decretação do perdimento de bens ser, nos termos da lei, estendidas aos sucessores e contra eles executadas, até o limite do valor do patrimônio transferido.

${ }^{22}$ Decreto Lei $2.848 / 40$, Art. 29 - Quem, de qualquer modo, concorre para o crime incide nas penas a este cominadas, na medida de sua culpabilidade.

${ }^{23}$ MACHADO, Hugo de Brito. Responsabilidade Penal no Âmbito das Empresas, in Direito Penal Empresarial, São Paulo: Dialética, 2001, p. 123.
} 
É inadmissível, pois, a imputação de responsabilidade penal objetiva a administradores pelo simples fato de terem cargos de gerência e sem que existam indícios da participação deles na prática de qualquer irregularidade. A jurisprudência corrobora este entendimento:

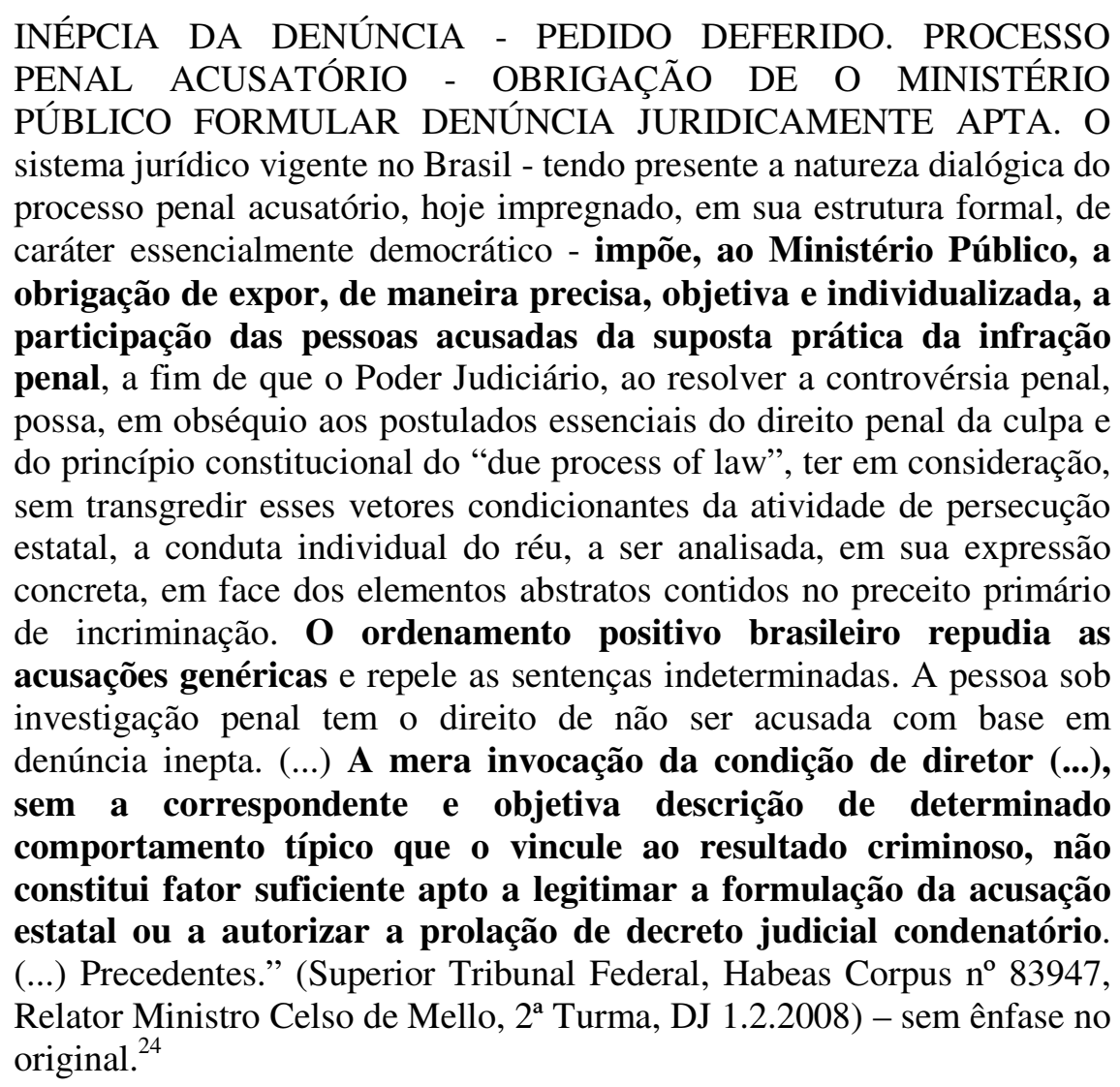

Destarte, em tese, o administrador somente responde pelos crimes praticados durante a sua gestão para os quais tenha concorrido, de forma ativa ou omissiva, ainda que não mais integre o quadro administrativo da companhia.

Do mesmo modo, não deve o administrador responder criminalmente por atos ou fatos ocorridos durante a gestão de seu antecessor, ressalvado que, caso o administrador tome conhecimento de procedimentos irregulares iniciados na gestão precedente, mas que

\footnotetext{
${ }^{24}$ Neste mesmo sentido, "CRIMINAL. HC. CRIME CONTRA AS RELAÇÕES DE CONSUMO. TRANCAMENTO DE AÇÃO PENAL. INÉPCIA DA DENÚNCIA. CRIME SOCIETÁRIO. NECESSIDADE DE DESCRIÇÃO MÍNIMA DA RELAÇÃO DO PACIENTE COM OS FATOS DELITUOSOS. OFENSA AO PRINCÍPIO DA AMPLA DEFESA. ORDEM CONCEDIDA. [...] III. O simples fato de ser sócio ou acionista de empresa não autoriza a instauração de processo criminal por crimes praticados no âmbito da sociedade, se não restar comprovado, ainda que com elementos a serem aprofundados no decorrer da ação penal, a mínima relação de causa e efeito entre as imputações e a sua função na empresa, sob pena de se reconhecer a responsabilidade penal objetiva.[...]" (Superior Tribunal de

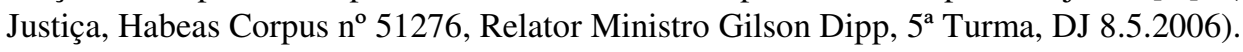


tenha continuidade durante a gestão atual e não tome as providências para impedir ou fazer cessar tais procedimentos, seria possível sua responsabilização criminal.

Sobre a questão da individualização da responsabilidade penal no âmbito da administração das sociedades, ainda pairam diversas indefinições, notadamente em virtude da dificuldade de se identificar os indivíduos responsáveis pela suposta prática criminosa. Por isso, por vezes, as autoridades públicas consideram suspeitas todas as pessoas físicas que detinham cargo estatutário à época dos fatos investigados.

Assim, somente poderiam responder pela conduta criminosa aqueles que com ela efetivamente tenham concorrido. Inclusive, esta individualização é de suma importância para o seguro na medida em que a negativa de cobertura fundada na prática de ato doloso por um determinado administrador eventualmente pode implicar negativa aos demais administradores da mesma companhia que não tenham participado da conduta, conforme examinado a seguir.

\subsection{RESPONSABILIDADE CIVIL}

\subsubsection{CONSIDERAÇÕES SOBRE A RESPONSABILIDADE CIVIL NO BRASIL}

No direito brasileiro, a noção de responsabilidade civil, inicialmente prevista no Código Criminal de 1830, condicionava-se à condenação penal que ensejava a reparação natural, quando possível, ou a indenização. Anos mais tarde, com a dissociação das jurisdições civil e criminal, a extinta Lei $\mathrm{n}^{\mathrm{o}} 3.071$ de $1^{\circ}$ de janeiro de 1916 - a qual instituiu o código civil que antecedeu o atual código vigente ("Código Civil de 1916") - filiou-se à teoria subjetiva (teoria da culpa), que exige a prova de culpa ou dolo do causador do dano para que seja obrigado a repará-lo, presumindo-se a culpa do agente em alguns poucos casos (e.g., art. 1.528$)^{25}$.

Acompanhando o desenvolvimento industrial e a multiplicação dos danos, assistiuse ao deslocamento do fulcro da responsabilidade civil, agora não mais tão centrada no dano, mas sim naquele que restou prejudicado por ele. Com isso, destacaram-se

${ }^{25}$ Conforme GONÇALVES, Carlos Roberto. Direito Civil Brasileiro, v. 4, $4^{\mathrm{a}}$ ed, São Paulo: Saraiva, 2009, p. 9. 
especialmente as teorias que colocam a vítima do dano como centro de preocupação da responsabilidade civil.

Como a teoria da culpa impõe à vítima a prova da culpa do causador, o advento da revolução industrial, com a consequente multiplicação de acidentes e danos causados pelo desenvolvimento tecnológico, fez com que fosse revisitado o regime de responsabilidade calcado na culpa ${ }^{26}$.

Com efeito, o direito voltou-se para a vítima, ganhando força a teoria do risco que, sem prejuízo da teoria da culpa, abrange hipóteses em que as teorias tradicionais revelamse insuficientes para conferir proteção à vítima. Nas palavras de Silvio Rodrigues:

\begin{abstract}
A teoria do risco é a da responsabilidade objetiva. Segundo essa teoria, aquele que, através de sua atividade, cria um risco de dano para terceiros deve ser obrigado a repará-lo, ainda que sua atividade e seu comportamento sejam isentos de culpa. Examina-se a situação, e, se for verificada, objetivamente, a relação de causa e efeito entre o comportamento do agente e o dano experimentado pela vítima, esta tem direito de ser indenizada por aquele ${ }^{27}$.
\end{abstract}

Apesar de o artigo 927 do Código Civil brasileiro, conforme introduzido pela Lei n 10.406 de 10 de janeiro de 2002 (“CC/02”), manter o princípio da responsabilidade com base na culpa ${ }^{28}$, o parágrafo único deste mesmo artigo reflete a tendência moderna, acolhendo o princípio da responsabilidade independente de culpa nos casos previstos em lei e nas hipóteses em que a natureza da atividade envolve riscos de grau elevado.

Dessa linha de pensamento, derivaram algumas correntes associadas à teoria do risco, por vezes um tanto extremadas, como constata Caio Mário da Silva Pereira:

Como sói acontecer, especialmente no surgimento de uma nova doutrina, logo se multiplicaram os seus extremos. Daí surgiram, em torno da idéia

\footnotetext{
26، A insuficiência da fundamentação da teoria da culpabilidade levou à criação da teoria do risco, com vários matizes, que sustenta ser o sujeito responsável por riscos ou perigos que sua atuação promove, ainda que coloque toda diligência para evitar o dano." VENOSA, Sílvio de Salvo. Direito Civil - Responsabilidade Civil, $4^{\text {a }}$ ed., São Paulo: Atlas, 2004, pp. 14-15.

${ }^{27}$ RODRIGUES, Silvio. Direito Civil - Responsabilidade Civil, 19a ed., São Paulo: Saraiva, 2002, p. 11.

${ }^{28}$ Art. 927 - Aquele que, por ato ilícito (vide arts. 186 e 187 do CC), causar dano a outrem, fica obrigado a repará-lo. Parágrafo único. Haverá obrigação de reparar o dano, independentemente de culpa, nos casos especificados em lei, ou quando a atividade normalmente desenvolvida pelo autor do dano implicar, por sua natureza, risco para os direitos de outrem.
} 
central do risco, configurações que se identificam como certas modalidades ou especializações. Assim é que, para alguns, responsável é aquele que tira o proveito, raciocinando que onde está o ganho aí reside o encargo - ubi emolumentum ibi onus. Esta concepção batizou-se com o nome de teoria do risco-proveito. Para outros, o que prevalece é o risco profissional, considerando-se o dever de indenizar quando o fato prejudicial é uma decorrência da atividade ou profissão do lesado. Num outro sentido, dá-se realce à idéia segundo a qual a reparação é devida quando o dano é conseqüência de um risco excepcional, que escapa da craveira comum da atividade da vítima, ainda que estranho ao trabalho que normalmente exerça. No campo do direito público, e enfocando a responsabilidade civil do Estado, enfrentou-se a teoria da culpa e do mau funcionamento do serviço público (teoria do acidente administrativo), que assumiu as preferências, inclusive ganhando o nosso direito positivo constitucional (como demonstrei no Capítulo X) tomou maiores proporções a teoria do risco integral, como o meio de repartir por todos os membros da coletividade os danos atribuídos ao Estado ${ }^{29}$.

A teoria do risco possui ainda outras ramificações que não serão abordadas neste estudo. Importa aqui analisar especificamente como se comporta a responsabilidade civil no âmbito do exercício da atividade empresarial e como o seguro veio remediar o dilema instaurado entre a tutela à vítima de dano e a proteção aos riscos relacionados à consecução da atividade econômica.

\subsubsection{A RESPONSABILIDADE CIVIL, O EXERCÍCIO DA ADMINISTRAÇÃO E A CONSAGRAÇÃO DO SEGURO DE RESPONSABILIDADE CIVIL}

Especificamente no âmbito do direito de empresa, o rigor da teoria do risco e o fortalecimento da tendência de imputação de responsabilidade objetiva criaram a natural necessidade de exonerar os empresários das severas consequências da responsabilidade, sob pena de atravancar o exercício da atividade empresária.

Era preciso remediar os extremos mediante a implementação de mecanismos suficientemente eficazes para, de um lado, garantir a condução da atividade empresária, sem que o risco profissional inerente a ela implicasse atravancar os negócios sociais e tolher o arbítrio dos administradores e, de outro, assegurar o direito do prejudicado ao ressarcimento do dano.

${ }^{29}$ PEREIRA, Caio Mario da Silva. Responsabilidade civil, $9^{\mathrm{a}}$ ed., Rio de Janeiro: Forense, 2001, p. 229-230. 
Era o momento oportuno para a consagração do seguro de responsabilidade civil. Durante longo tempo, duas forças contiveram a expansão deste seguro: (i) a inexistência de responsabilidade sem culpa; e (ii) a negativa de cobertura da seguradora nos casos de culpa do segurado.

A paulatina assimilação da ideia de responsabilidade, associada ao risco em substituição à noção de responsabilidade exclusivamente relacionada com a culpa, cuidou de suprimir a primeira força. A segunda, por sua vez, custou a ser enfraquecida, sobretudo porque o Código Civil de 1916 declarava ser expressamente nulo o contrato cujos riscos derivassem de ato ilícito ${ }^{30}$.

Em linha com as novas concepções doutrinárias e jurisprudenciais, bem como com o desenvolvimento industrial e tecnológico, constatou-se que o ato danoso não necessariamente derivava de um ato ilícito culposo e que o simples exercício de uma atividade poderia implicar prejuízo a terceiro.

A consolidação deste entendimento estimulou o estabelecimento de um sistema em que o dever de indenizar não se restringia ao dano resultante de ato ilícito decorrente de comportamento doloso ou culposo, e sim ao dano decorrente de qualquer atividade da qual resultasse uma lesão a terceiro. Por conseguinte, todo aquele que, no exercício de sua atividade, criava uma situação de risco para a coletividade, podia ser responsabilizado.

A atividade empresarial, por trazer consigo o risco intrínseco ao exercício dos negócios, potencializa o risco de danos à comunidade. Assim sendo, entendia-se ser justo que o risco fosse suportado pelo autor da iniciativa econômica, bastando que a vítima demonstrasse o nexo de causalidade entre o dano e a conduta do agente para que surgisse o dever de indenizar.

Ocorre que a primazia da teoria do risco, sobretudo no setor empresarial, poderia comprometer o desenvolvimento da atividade empresarial, haja vista a magnitude de determinados prejuízos por ela gerados. Caso tivessem que ser exclusivamente arcados

\footnotetext{
${ }^{30}$ Art. 1.436 do Código Civil de 1916 - Nulo será este contrato, quando o risco, de que se ocupa, se filiar a atos ilícitos do segurado, do beneficiado pelo seguro, ou dos representantes e prepostos, quer de um, quer do outro.
} 
pelo agente (independente da prova de culpa ou da ilicitude do ato causador do dano), tais prejuízos possivelmente inviabilizariam a atividade econômica.

No outro extremo, a prevalência absoluta da teoria da culpa eventualmente acabaria por deixar desamparados aqueles que fossem prejudicados pela atividade empresarial e que não fossem capazes de comprovar a culpa do agente na configuração do dano que os lesou.

Acerca da questão, J. Efrén Ossa G. observa que não é prudente expor pequenos capitais aos perigos que frequentemente envolvem as atividades produtivas. Desta forma, o seguro promove a produção, na medida em que elimina os temores e neutraliza tecnicamente seu efeito inibidor sobre a iniciativa privada. $\mathrm{O}$ seguro garante a subsistência do capital e, portanto, a do negócio a que se vincula. E este aspecto, por si só, permite medir sua influência na estabilidade e no incremento da produção ${ }^{31}$.

Esta realidade evidenciou que não seria viável um sistema jurídico partidário apenas da teoria do risco ou da teoria da culpa. Com efeito, a dualidade de teorias tornou imprescindível a busca por um regime equilibrado que colhesse alguns elementos de cada uma delas, de modo a assegurar, simultaneamente, o desenvolvimento da atividade empresarial e a certeza de reparação dos danos decorrentes de tal atividade.

Para tanto, recorreu-se ao seguro de responsabilidade civil que, alinhado com a tendência de substituição da ideia de culpa pela ideia de dano, bem como com o afastamento da noção de responsabilidade da noção de culpa, buscou tutelar tanto os interesses dos prejudicados, quanto os interesses dos agentes causadores do dano.

\subsubsection{FUNÇÃO DA RESPONSABILIDADE CIVIL DOS ADMINISTRADORES}

Independente da corrente teórica preponderante, o regime da responsabilidade civil positivado no direito brasileiro consiste em um importante instrumento para garantir a

\footnotetext{
${ }^{31}$ Nas palavras do autor: "No es prudente exponer pequenos capitales, cuando ellos representan el único patrimonio, a los peligros que frecuentemente aparejan las atividades productivas. [...] Así promueve el seguro la producción, despejando los temores, neutralizando ténicamente su efecto inhibidor sobre la iniciativa privada. [...] El seguro garantiza la subsistencia del capital y, por tanto, la del negocio a que está vinculado. Y por este solo aspecto puede mediarse su influjo decisivo en la estabilidad e incremento de la producción.”. OSSA G., J. Efrén, Teoría General del Seguro - La Institución: Aspectos técnicos, económicos, políticos y comerciales del seguro, Bogotá: Temis, 1988, pp. 177-178.
} 
manutenção do equilíbrio entre a liberdade de atuação e os deveres sociais que incumbem a cada pessoa.

Tem como função primordial, em um primeiro momento, a reparação do dano (intento inerente a toda ação de responsabilidade civil), isto é, o sistema jurídico focado na vítima do dano proporciona ao lesado mecanismos para restituir o estado anterior ao prejuízo que lhe foi causado.

Assim, buscando harmonizar a liberdade e a conduta dos indivíduos, o sistema estabelece regras de conduta na esfera civil e estipula ainda que, do dano gerado pela inobservância de tais regras, emergirá a responsabilidade civil por ato ilícito ${ }^{32}$.

Não obstante serem o atendimento à vítima e a reparação do dano o foco central da responsabilidade civil, a função do instituto, sobretudo no que tange à responsabilização dos administradores, não se restringe à imposição da obrigação de reparação do dano na hipótese de ato ilícito causador de lesão a terceiro. Ele atua também como instrumento de coibição de condutas ilegais.

A respeito desta segunda função, Nelson Eizirik pondera que "ao analisarmos a responsabilidade civil dos administradores de companhias abertas, verificamos outra função importante na sua disciplina, além daquela referente à manutenção do equilíbrio nas relações privadas",33.

Examinando a prática norte-americana, cujo modelo de regulação do mercado de capitais está intimamente ligado ao desenvolvimento de ações de responsabilidade civil movidas por investidores, o referido autor constata que os incentivos à propositura de ações desta natureza guardam relação com o papel que assumem tais ações, as quais, nas palavras dele, "são visualizadas não apenas como instrumento de recomposição de prejuízos, mas também como fator de prevenção de condutas ilegais",34.

\footnotetext{
${ }^{32}$ Conforme EIZIRIK, Nelson. Responsabilidade Civil e Administrativa do Diretor de Companhia Aberta, in Revista de Direito Mercantil, Industrial, Econômico e Financeiro, ano XXIII, nº 56, out/dez, 1984, p. 47.

${ }^{33}$ EIZIRIK, Nelson. op. cit., p. 49.

${ }^{34}$ EIZIRIK, Nelson, op. cit., loc. cit.
} 
Esta segunda função adquire especial relevo para este trabalho, pois é justamente pelo fato de a responsabilidade civil ter por finalidade indireta a contenção de práticas inadequadas por parte dos administradores que se questiona se o seguro de responsabilidade civil não caminharia na contramão do propósito pretendido pela norma, conforme analisado na sequência.

\subsection{RESPONSABILIDADE ADMINISTRATIVA}

A responsabilidade administrativa funda-se sobretudo na capacidade que as pessoas jurídicas de direito público possuem de impingir condutas ao administrado: trata-se do poder administrativo, inerente à Administração dos entes políticos, observados os limites das respectivas competências institucionais ${ }^{35}$.

No que tange aos poderes da Administração, merece destaque para este trabalho o poder de polícia administrativa, descrito por Hely Lopes Meirelles como aquele que "a Administração Pública exerce sobre todas as atividades e bens que afetam ou possam afetar a coletividade ${ }^{36,}$.

Diversas são as autoridades públicas que exercem este poder sobre as companhias e seus administradores, tais como a Comissão de Valores Mobiliários (“CVM”), o Banco Central do Brasil e Conselho Administrativo de Defesa Econômica, entre outras. Em se tratando de violação da LSA e da regulamentação atinente ao mercado de capitais na órbita administrativa, contudo, a apreciação da responsabilidade administrativa cumpre exclusivamente à $\mathrm{CVM}^{37}$.

A Lei $n^{\circ} 6.385$ de 7 de dezembro de 1976 ("Lei 6.358/76") instituiu a CVM, dotando-lhe de poderes para disciplinar e normatizar o mercado de capitais. Nos termos do artigo $8^{\circ}$ da referida lei, tal autarquia será competente para apurar e punir condutas fraudulentas no mercado de valores mobiliários sempre que: (i) seus efeitos ocasionem danos a pessoas residentes no território nacional, independentemente do local em que

\footnotetext{
${ }^{35}$ Conforme MEIRELLES, Hely Lopes. Direito Administrativo Brasileiro. (atual. por Eurico de Andrade Azevedo, Délcio Balestero Aleixo e José Emmanuel Burle F.), $21^{\text {a }}$ ed., São Paulo: Malheiros, 1996, p. 101. Vide também SILVA, José Afonso da. Direito Ambiental Constitucional. 5a ed., São Paulo: Malheiros, 2004. ${ }^{36}$ MEIRELLES, Hely Lopes, op. cit., p. 114.

${ }^{37}$ Conforme EIZIRIK, Nelson, op. cit., p. 58.
} 
tenham ocorrido; e (ii) os atos ou omissões relevantes tenham sido praticados em território nacional.

No exercício desta função, a CVM está autorizada, por esta mesma lei, a impor as penalidades cabíveis aos infratores. A exposição de motivos da Lei 6.385/76 revela a importância da atividade sancionadora da CVM:

13. Pouca ou nenhuma eficácia teria a ação fiscalizadora da Comissão de Valores Mobiliários, se esta não dispusesse de um sistema de sanções disciplinadoras contra as infrações do mercado. Por isso, o projeto prevê um conjunto de penalidades, que poderão ser aplicadas pela Comissão[...].

Ademais, o Regimento Interno da $\mathrm{CVM}^{38}$ prevê, dentre as finalidades desta autarquia, a proteção aos titulares de valores mobiliários e aos investidores do mercado contra atos ilegais de administradores e acionistas controladores das companhias abertas (artigo $3^{\circ}, \mathrm{IV}, \mathrm{b}$ ). Para tanto, o Regimento Interno faculta à CVM a aplicação, aos autores das infrações indicadas no inciso anterior, das penalidades previstas no artigo 11 da Lei 6.385/76, sem prejuízo da responsabilidade civil ou penal.

Como se nota, assim como ocorre com a responsabilidade civil, a responsabilidade administrativa também contempla a proteção a terceiros, visando a criar um ambiente seguro que estimule os investidores, que propicie o desenvolvimento do mercado e que seja benéfico à comunidade. É por este motivo que as questões práticas envolvendo a responsabilidade pessoal do administrador na esfera administrativa também merecem amparo do seguro de responsabilidade (vide seção 5.4.3).

\footnotetext{
${ }^{38}$ Aprovado pela Portaria do Ministério da Fazenda no 327 de 11 de julho de 1977.
} 


\section{HISTÓRICO, CARACTERÍSTICAS, FORMALIZAÇÃO E FINALIDADE DAS OPERAÇÕES DE SEGURO}

\subsection{HISTÓRICO}

O início das operações de seguro remete à Idade Antiga. Em verdade, em sua forma embrionária, as operações não eram propriamente de seguros, conforme concebidas no ordenamento atual.

Buscando afastar os riscos no comércio marítimo, os romanos faziam uso de um instituto denominado foenus nauticus, por meio do qual se mutuava uma determinada quantia ao armador do navio para utilização em uma operação comercial. Em tendo êxito a viagem, a quantia era devolvida ao mutuante, acrescida de juros. Se mal sucedida, nada seria devido a ele.

Como se nota, não se tratava de operação de seguro em sentido técnico, mas sim de uma operação de transferência do risco que incidia sobre uma operação principal (no exemplo citado, uma operação de crédito) ${ }^{39}$.

Séculos mais tarde, na Idade Média, foram criadas associações de socorro mútuo, as guildas medievais, cuja função assistencialista era de ressarcir os associados de eventuais danos decorrentes de incêndio, roubo, comprometimento do gado e outros eventos que abalassem as finanças dos associados. Não se tratava, no entanto, de diluir ou pulverizar o risco, mas apenas de partilhá-lo entre os associados ${ }^{40}$.

Como se nota, um dos elementos principais do seguro - o risco - já estava presente, mas, tendo em vista a maneira como eram estruturadas as operações conduzidas por tais

\footnotetext{
39،"Sinteticamente, a operação nada mais era do que um contrato de mútuo, cujo pagamento pelo mutuário subordinava-se a uma condição: a de que a empreitada fosse bem sucedida. E não se podia qualificar como seguro, porque o risco permanecia. Ele não era diluído, pulverizado, mas transferido integralmente para o outro integrante da operação." FRANCO, Vera Helena de Mello, Contratos: direito civil e empresarial, São Paulo: Revista dos Tribunais, 2011, p. 275-276.

${ }^{40}$ De acordo com Antigono Donati et al., na Idade Média, o fenômeno associativo, ainda que secundário, de assistência, faz-se de caráter geral e o instituto que domina neste campo é a guilda anglo-saxã, especialmente contra os incêndios e os naufrágios. Nas palavras do autor: "Nel Medio Evo il fenomeno associativo a scopo, sia pure secondario, di assistenza, si fa generale e l'istituto che domina in questo campo è la gilda anglosassone, specie contro gli incendi e i naufragi." DONATI, Antigono e PUTZOLU, Giovanna Volpe. Manuale di Diritto delle Assicurazioni Private, $3^{\mathrm{a}}$ ed., Milano: Dott. A. Giuffrè Editore, 1987, p.11.
} 
associações, não se podia falar propriamente em operações de seguros, pois elas não comportavam a prevenção do risco, e sim sua transferência ou seu compartilhamento.

O surgimento das operações de seguros propriamente ditas se deu ao final do século $\mathrm{XV}$, inauguradas no ramo do seguro marítimo ${ }^{41}$. No caso, o segurador prometia pagar, em troca de uma contraprestação fixa, uma quantia determinada que somente seria devida caso o navio ou sua carga não alcançassem seu destino final. Assim nascia a ideia de assunção do risco mediante o pagamento de um prêmio.

Entretanto, vale ressaltar que, mesmo possuindo a estrutura que mais se assemelha às operações de seguros como são conhecidas hoje, tais operações não eram exatamente de seguro, pois estava ausente a função de previdência do risco. Ademais, o risco não era pulverizado, mas transferido ao segurador, o que acabava por gerar ainda um segundo risco: o de insolvência do segurador.

A origem efetiva das operações do seguro como concebidas atualmente remonta ao século XVII, com a criação das primeiras companhias náuticas e a transposição do cálculo das probabilidades para a técnica securitária. Foi neste contexto que se revelaram os elementos extrajurídicos das operações de seguros, como as ciências matemáticas, a estatística e a atuária.

O seguro de responsabilidade civil também teve origem no direito marítimo. Seu progresso, contudo, como ensina Isaac Halperin, viu-se dificultado em virtude de dois princípios, hoje em franco declínio: a inexistência de responsabilidade sem culpa e o fato de a seguradora estar impedida de indenizar os danos decorrentes de fatos ou atos culposos do segurado ou seus dependentes ${ }^{42}$.

\footnotetext{
${ }^{41}$ Remontando a história dos seguros, Picard e Besson contam que o seguro marítimo apareceu como uma instituição organizada a partir do século XV, mas ainda associado à noção de aposta e estabelecido sem bases estatísticas. In verbis: "Tout en étant encore fortement imprégnée de l'idée de jeu et établie sans base statistique sérieuse, l'assurance maritime apparait, dès le XVe siècle, comme une instituition organisée." PICARD, M. e BESSON, A. Les Assurances Terrestres. Tome Premier, $5^{\text {a }}$ ed, Paris: Librarie Générale de Droit et de Jurisprudence, 1982, p. 3.

${ }^{42}$ Nos dizeres do autor: "El seguro de la responsabilidad civil halla su origen en el resarcimiento del abordaje en el derecho marítimo. Su progresso se vio dificultado por dos principios, hoy en franca declinación: que no hay responsabilidad sin culpa, y que el asegurador no indemniza los daños derivados de actos o hechos culposos del asegurado o de sus dependientes." HALPERIN, Isaac. Seguros. v.1, $2^{\mathrm{a}}$ ed., Buenos Aires: Ediciones Depalma, 1983, p. 4.
} 
Embora estejam de fato superados estes entraves ao seguro de responsabilidade civil, as controvérsias que ainda pairam sobre esta modalidade de seguro guardam relação com as questões de culpabilidade sobre o ato do segurado, conforme será estudado oportunamente.

\subsection{ASPECTOS JURÍDICOS E EXTRAJURÍDICOS DAS OPERAÇÕES DE SEGURO}

A estrutura e o funcionamento das operações de seguro, mesmo que fundamentalmente embasados no ordenamento jurídico, estão atrelados a elementos extrínsecos ao arcabouço legal, tais como a técnica atuarial e as ciências exatas, fundamentos igualmente essenciais à efetividade do seguro ${ }^{43}$.

Vera Helena de Mello Franco propõe a análise das operações de seguro sob três prismas: (a) técnico-econômico; (b) jurídico; e (c) previdenciário.

O técnico-econômico fornece a base necessária a toda operação de seguros, calcado em duas diretrizes fundamentais: (i) a pulverização ou dispersão de risco; e (ii) mutualidade (comunidade de riscos).

Tais diretrizes desvelam o caráter empresarial de que se reveste a atividade securitária, pois ela pressupõe uma organização técnica de meios, instrumentos, bens e pessoas que é imprescindível para constituir a mutualidade e determinar os riscos a que se sujeita, permitindo sua diluição pelo agrupamento. Fundado nesta base e nas pesquisas estatísticas, o segurador pode prever a probabilidade de sinistros (incidência de risco) em uma determinada mutualidade, a qual resulta da agregação dos interesses submetidos aos mesmos riscos.

Sob a ótica jurídica, a operação de seguro apresenta-se sob a forma contratual. $\mathrm{O}$ instrumento contratual viabiliza a diluição ou a dispersão do risco pela seguradora pela mutualidade.

\footnotetext{
${ }^{43}$ Priscila M. P. Corrêa da Fonseca observa que "para que se possa fazer o seguro representar efetivamente o antídoto do risco, apoia-se o instituto em diferentes fundamentos extrajurídicos.” FONSECA, Priscila M. P. Corrêa. Contrato de Seguro. Contratos Nominados - Doutrina e Jurisprudência. São Paulo: Saraiva, 1995, p. 443.
} 
O caráter previdenciário da operação, por sua vez, impacta diretamente a aferição da extensão e da equivalência dos riscos, auxiliando a determinação da probabilidade de ocorrência de um evento que cause prejuízo, em sentido econômico, ao segurado.

A este respeito, cabe salientar que a reparação por parte da seguradora tem sempre conteudo econômico e visa à recomposição do patrimônio do segurado, o que não significa que qualquer forma de compensação econômica de dano decorra de uma operação de seguro. Esta última impõe que a compensação resulte da repartição das consequências de um sinistro (materialização do risco) por um grande número de patrimônios submetidos ao mesmo risco ${ }^{44}$.

A mutualidade é um pressuposto para a caracterização das operações de seguro, pois é preciso que elas sejam realizadas em massa. Fosse a operação de seguro uma relação isolada, ter-se-ia somente um contrato de transferência de riscos ${ }^{45}$. É ainda a mutualidade que garante a finalidade do seguro, que é justamente fragmentar o risco, diluindo seus efeitos econômicos entre os titulares de interesses sujeitos ao mesmo risco ${ }^{46}$.

Cada um dos titulares que se reune em torno de um interesse comum então paga uma contribuição (prêmio) que comporá um fundo comum (gerido pelo segurador) apto a fazer frente aos pagamentos de sinistros que venham a ocorrer no âmbito daquele agrupamento.

Os aspectos técnico-econômicos, jurídicos e previdenciários são indissociáveis e determinantes para que os riscos que emanam das operações de seguro, por seu tipo, sejam calculados e alocados adequadamente na base segurada.

\footnotetext{
44“'Somente se terá uma operação de seguros quando a reparação decorrer de um sistema de compensação entre patrimônios ameaçados do mesmo modo, pelos mesmos riscos." FRANCO, Vera Helena de Mello, op. cit., p. 279.

45،O risco não se transfere para a seguradora. [...] Ela apenas garante que as consequências do eventual sinistro (ocorrência do risco) que se quer evitar serão compensadas economicamente. A sua prestação é uma prestação de segurança, de garantia.” FRANCO, Vera Helena de Mello, op. cit., p. 279.

${ }^{46}$ Ensinam Picard e Besson que, para atender sua finalidade, qual seja, neutralizar os efeitos do acaso compensando os riscos no seio da mutualidade, o seguro pressupõe o agrupamento de uma multiplicidade de riscos, do maior número possível de riscos. In verbis: "Pour pouvoir atteindre son but, à savoir régulariser les effets du hasard em compensant les risques au sein de la mutualité, l'assurance suppose le groupement d'une multitude de risques, du plus grand nombre possible de risques.” PICARD, M. e BESSON, A., op. cit., p. 19.
} 


\subsection{CONTRATO DE SEGURO}

\subsubsection{NATUREZA DO CONTRATO E IMPORTÂNCIA DA TÉCNICA CONTRATUAL}

O contrato de seguros é um contrato bilateral, por adesão, oneroso, consensual, comutativo e de boa fé.

O aperfeiçoamento do contrato de seguros, por sua bilateralidade, se dá no momento do alinhamento da vontade das partes. Todavia, para a formação do regulamento contratual, contribui outra fonte: o Poder Público, que atua tanto com relação ao impulso que determina a contratação do seguro (como é o caso dos seguros obrigatórios) como com relação ao conteúdo, estabelecendo cláusulas obrigatórias que comporão as condições gerais dos seguros privados.

É bom lembrar que tais características, respeitados os limites regulamentares, não usurpam a livre vontade das partes para pactuar cláusulas. Somente não é possível conferir maior abertura às tratativas entre as partes por ser o seguro uma operação realizada em massa. Daí decorre o fato de ser o contrato de seguros um contrato por adesão ${ }^{47}$.

Mais uma vez cumpre frisar que estes traços não comprometem o equilíbrio contratual nas operações de seguro. Trata-se de contrato sinalagmático, pois ele prevê obrigações relevantes para ambos os contratantes. Grosso modo, o segurado paga o prêmio e se obriga a cumprir uma série de deveres (e.g., comunicar à seguradora alteração do risco, tomar providências para minorar o dano, dentre outros) e a seguradora assume a obrigação de pagar a prestação convencionada em caso de sinistro ${ }^{48}$.

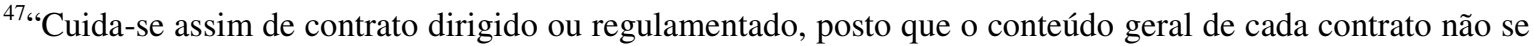
regula por pactos variáveis de contrato para contrato, mas, sim, por normas prefixadas nas condições gerais emanadas da SUSEP. Isto, porém, não veda a presença de cláusulas facultativas da livre escolha das partes. Ao par disso, como mencionado, é sempre um contrato realizado em massa, posto que o seguro não exista como operação de prevenção de riscos sem a presença da mutualidade. E, por cuidar-se de contrato realizado em massa, a fase de punctuação (discussão preliminar) está afastada. É, assim, um contrato por adesão." FRANCO, Vera Helena de Mello, op. cit., p. 284.

${ }^{48}$ Conforme Isaac Halperin: "el asegurado asume la obligación de pagar la prima e importantes cargas, y el asegurador asume la obligación de pagar la prestación convenida en caso de siniestro." HALPERIN, Isaac, op. cit., v.1, p. 31.
} 
Vale apenas lembrar que as obrigações da seguradora não têm caráter meramente eventual, pois, na medida em que se compromete a garantir o interesse legítimo do segurado, ela se obriga a manter o valor do fundo formado pelo conjunto de prêmios recebidos. Perfaz-se, pois, a proporcionalidade entre os deveres e obrigações.

A propósito das obrigações das partes supracitadas, tem-se que o contrato de seguro é oneroso, uma vez que há prestações para ambas, e consensual, visto que se aperfeiçoa mediante acordo de vontades formalizado pela apresentação da proposta pelo segurado e sua aceitação, pela seguradora, mediante a emissão da apólice ou bilhete de seguros pela seguradora.

Afora as classificações jurídicas em que se enquadram os contratos de seguro e que não suscitam maiores questionamentos, a principal discussão ainda repousa sobre ser ou não o contrato de seguro um contrato aleatório. Apesar de alguns doutrinadores defenderem que o contrato seria aleatório pelo fato de a prestação da seguradora estar condicionada à verificação do sinistro $^{49}$ - que, como evento incerto, poderia nunca ocorrer - a prestação da seguradora não se associa somente à indenização, mas sim à prestação da garantia.

A noção de aleatoriedade, a nosso ver, relaciona-se à equivocada percepção de que a contraprestação da seguradora nos termos do contrato de seguro é meramente pecuniária. De fato, o pagamento da indenização está condicionado à ocorrência do sinistro. Contudo, as obrigações da seguradora não se resumem a prestações pecuniárias: a seguradora tem a obrigação de garantir o ressarcimento do dano ao bem segurado. Desta decorre uma segunda obrigação não pecuniária, que é a de manter reservas suficientes para atender a base de segurados quando acionadas.

\footnotetext{
${ }^{49}$ Conforme Carlos Alberto Gonçalves: “embora o segurado assuma obrigação certa, que é a de pagar o prêmio estipulado na apólice, a avença é sempre aleatória para o segurador, porque a sua prestação depende de fato eventual: a ocorrência ou não do sinistro." GONÇALVES, Carlos Roberto. Direito Civil Brasileiro: contratos $e$ atos unilaterais. São Paulo: Saraiva, 2004, p. 475. Na mesma linha, Isaac Halperin: "Es un contrato aleatorio. [...] Quienes niegan este carácter no reparan que justamente la prima se mide por el álea." HAPERIN, Isaac. op. cit., v.1, p. 34. Vide também PICARD, M. e BESSON, A., op. cit., pp. 66-67; VENOSA, Silvio de Salvo. Direito Civil: contratos em espécie. São Paulo: Atlas, 2009, p. 336.
} 
Inclusive, a substituição do termo "indenização" ora empregado pelo Código Civil de 1916 pela noção de "garantia" introduzida pelo CC/02 $2^{50}$. Parece-nos, portanto, equivocada a ideia de que a prestação da seguradora corresponde ao montante devido pelo sinistro.

Sem entrar na discussão etimológica, o verbo "garantir" já denota que a obrigação da seguradora perante o segurado se verifica desde o aperfeiçoamento do contrato de seguros. Isto porque a prestação que lhe incumbe é a de oferecer garantia para que o patrimônio do segurado não seja dilapidado em razão de um sinistro.

A respeito da álea, preconiza Pontes de Miranda:

Quem joga ou aposta cria álea. Ou perde ou ganha, porque jogou ou apostou. Quem segura de modo nenhum cria álea. [...] No contrato de seguro, pré-elimina-se a álea, prevê-se e por isso se quer a promessa do segurador, razão para se aludir a função de previdência ${ }^{51}$.

Em linha com o posicionamento de Pontes de Miranda, que defende ainda não se tratar o seguro de obrigação de ressarcimento, mas sim de garantia da dívida, Vera Helena de Mello Franco afirma que como o risco não é propriamente dano (e sim uma possibilidade de dano), a finalidade do seguro não seria de ressarcir um dano em concreto, mas sim de garantir contra a expectativa de dano ${ }^{52}$.

Justamente por se tratar de expectativa de dano, o aparato técnico-econômico é tão fundamental para determinar em que medida é possível agrupar, para então pulverizar os riscos. Isto prova, inclusive, que o pilar técnico-econômico é um dos grandes (se não o principal) alicerces do seguro, porque afasta a suposta álea da operação. O afastamento da álea é imprescindível às operações de seguro, pois a contraprestação da seguradora (qual seja, a prestação de garantia de indenização) somente se torna viável mediante a previsão e o compartilhamento dos riscos, os quais são viabilizados pelos cálculos atuariais ${ }^{53}$.

\footnotetext{
${ }^{50}$ Art. 757 - Pelo contrato de seguro, o segurador se obriga, mediante o pagamento do prêmio, a garantir interesse legítimo do segurado, relativo a pessoa ou a coisa, contra riscos predeterminados.

${ }^{51}$ MIRANDA, Francisco Cavalcanti Pontes de. Teoria de Direito Privado - Direito das Obrigações: contrato de seguro, Campinas, Bookseller, v. 45, 2006, p.396-397.

${ }^{52}$ FRANCO, Vera Helena de Mello, op. cit., p. 291.

${ }^{53}$ De acordo com Priscila M. P. Corrêa da Fonseca, o cálculo das probabilidades permite "prever co, com grande aproximação, o número de sinistros que, de um determinado tipo, deverão verificar-se em uma dada localidade, dentro de certo prazo." FONSECA, Priscila M. P. Corrêa da, op. cit., p. 443.
} 
A matemática tornou possível a previsão racional do acaso mediante a análise da incidência de certo evento em um determinado espaço amostral de experiências. Verificouse, assim, que quanto maior o número de experiências, mais a previsão da possibilidade de ocorrência de determinado evento apresentaria relativo grau de certeza.

Por fim, outra característica essencial aos contratos de seguro é a boa-fé. A operação de seguros está calcada na informação. No caso, a fonte da informação são duas: as declarações do segurado e os dados estatísticos. A informação é elemento essencial na contratação do seguro, pois permite que a seguradora afaste incertezas (elemento nãoquantificável) e possa, assim, quantificar o risco e otimizar os resultados.

A boa-fé é fundamental na medida em que a subscrição do risco pela seguradora leva em conta as informações prestadas pelo segurado. Logo, se as declarações do segurado estiverem impregnadas de má-fé, os padrões do contrato definidos pela a seguradora apresentarão vício. Por ser o seguro regido pelo princípio da garantia, a má-fé pode resultar no não pagamento da indenização, ainda que a informação não tiver tido ligação direta com o sinistro.

A boa-fé é tão essencial ao contrato de seguro que, conforme observam Ernesto Tzirulnik et al., mesmo o CC/02 trazendo a boa-fé como cláusula geral para a interpretação dos negócios jurídicos ${ }^{54}$ e para a execução dos $\operatorname{contratos}^{55}$, "as exigências de boa-fé e veracidade foram ressaltadas em relação ao contrato de seguro" ${ }^{" 56}$, conforme o artigo 765 do $\mathrm{CC} / 02^{57}$.

\footnotetext{
${ }^{54}$ Art. 113 - Os negócios jurídicos devem ser interpretados conforme a boa-fé e os usos do lugar de sua celebração.

${ }^{55}$ Art. 422 - Os contratantes são obrigados a guardar, assim na conclusão do contrato, como em sua execução, os princípios de probidade e boa-fé.

${ }^{56}$ TZIRULNIK, Ernesto et al. $O$ contrato de seguro de acordo com o novo código civil brasileiro. $2^{\mathrm{a}}$ ed., São Paulo: Revista dos Tribunais, 2003, p.73.

${ }^{57}$ Art. 765 - O segurado e o segurador são obrigados a guardar na conclusão e na execução do contrato, a mais estrita boa-fé e veracidade, tanto a respeito do objeto como das circunstâncias e declarações a ele concernentes.
} 


\subsubsection{ELEMENTOS DO CONTRATO}

Os elementos essenciais do contrato de seguro tratados neste capítulo são entendidos como os elementos categoriais inderrogáveis previstos no ordenamento pátrio que caracterizam o contrato de seguro e fixam o regime jurídico a que ele se submete, conforme extraídos do artigo 757 do $\mathrm{CC} / 02^{58}$. São eles o interesse legítimo, o risco, o prêmio e a garantia.

\subsubsection{INTERESSE LEGÍTIMO}

Como já dito anteriormente, o seguro não recai sobre a coisa ou pessoa, mas sim sobre o interesse do segurado em relação ao bem ou pessoa exposto ao risco. Nas palavras de Fábio Konder Comparato:

Na verdade, mesmo no chamado seguro de coisas determinadas, como o seguro de incêndio ou o seguro contra o furto, o que o segurado garante pelo contrato não é propriamente uma coisa, mas o interesse que possui em relação a esta coisa ${ }^{59}$.

Assim, o interesse, constituído pela relação entre uma pessoa e uma coisa, independe da noção de risco, pois ele existe ainda que não haja uma ameaça sobre ele. $\mathrm{O}$ interesse segurável, contudo, surge justamente em virtude da exposição desta relação a um risco. O segurado possui interesse legítimo sobre um bem na medida em que, no seu entender, esteja exposto a um risco que importe um dano patrimonial ou econômico.

Importante examinar também a adjetivação do termo interesse no CC/02. Em seu artigo $757^{60}$, o diploma determina que é obrigação do segurador garantir interesse legítimo. O intento da lei ao exigir legitimidade do interesse não se relaciona apenas à licitude do objeto do seguro, mas também ao objetivo de assegurar que o segurado tenha um real interesse em evitar que o sinistro ocorra.

Cabe salientar que o interesse passível de seguro é independente do interesse subjetivo do segurado de desejar obter uma garantia. Equivale dizer que a causa ou motivo

\footnotetext{
${ }^{58}$ Vide nota de rodapé $\mathrm{n}^{\circ} 50$.

${ }^{59}$ COMPARATO, Fábio Konder, Seguro de Crédito. São Paulo: Revista dos Tribunais, 1968, pp. 24-25.

${ }^{60}$ Vide nota de rodapé $\mathrm{n}^{\circ} 50$.
} 
que levou o segurado a contratar o seguro (interesse subjetivo) não se confunde com o interesse legítimo objeto do contrato de seguro (causa em sentido objetivo) ${ }^{61}$.

Antigono Donati adota o mesmo raciocínio ao esclarecer que o interesse segurável somente pode ser concebido de modo subjetivo, pois uma concepção objetiva está em contradição lógica com qualquer definição de interesse (no seguro), que sempre tem uma base subjetiva $^{62}$.

Conquanto a razão que motivou o segurado a contratar o seguro tenha sido seu interesse em resguardar-se de eventuais prejuízos econômicos ao seu patrimônio, a causa em sentido objetivo corresponde ao interesse objetivo, típico, referente a funções dignas de tutela e que serve de substrato constante e invariável a todas as operações típicas, configuradas em negócios consubstanciados sob a forma de um determinado contrato. Em matéria securitária, a tipicidade reside na prevenção do risco e na tomada de medidas para evitá-lo ${ }^{63}$.

Por suas características, o interesse legítimo pressupõe duas relações distintas: uma de natureza econômica e outra de natureza jurídica.

A de natureza econômica relaciona-se ao valor atribuído ao interesse que se pretende segurar, pois o evento que se pretende evitar deve ser passível de valoração patrimonial e trazer um prejuízo pecuniário ou de utilidade ao segurado ${ }^{64}$.

Segundo Antigono Donati, a relação entre o sujeito e o objeto do seguro tem que ser de natureza econômica, sendo ela necessária porque, para o seguro, não basta o caráter moral do interesse ${ }^{65}$.

\footnotetext{
${ }^{61}$ Trata-se de "um interesse objetivo, plausível e socialmente apreciável que, expresso no negócio abstratamente considerado, é diferente do interesse individual determinante da negociação." FRANCO, Vera Helena de Mello, op. cit., p. 302.

${ }^{62}$ Nas palavras do autor: "El interés sólo puede ser concebido de un modo subjetivo; uma concepción objetiva está en crontradicción lógica con cualquier definición del interés que siempre tiene una base subjetiva." DONATI, Antigono. Los Seguros Privados - Manual de Derecho. Barcelona: Libreria Bosch, 1960, p. 223. No mesmo sentido, vide HALPERIN, Isaac, op. cit, v.2, pp. 850-851.

63،"Perante o seguro, esta função constante e típica, peculiar de a toda operação securitária, é a prevenção de risco. Portanto, a causa em sentido objetivo, nos negócios de seguros, é a prevenção de riscos." FRANCO, Vera Helena de Mello, op. cit., p. 302.

64“"Pour être assurable, um interêt doit donc être économique et appréciable en argent." PICARD, M. e BESSON, A., op. cit., p. 296.
} 
A de natureza jurídica, por sua vez, tem relação com o interesse como pressuposto para formação do contrato de seguro, pois, além de lícito, o interesse legítimo deve preceder o contrato e estar presente no momento da contratação.

\subsubsection{RISCO}

De maneira geral, o risco pode ser definido como um evento futuro e incerto que independe da vontade humana, cujos efeitos irradiam na esfera jurídica. Em se tratando de seguros, o risco está associado à possibilidade de ocorrência de evento danoso ao segurado, que lhe atinja o patrimônio ${ }^{66}$.

Imprescindível salientar que o risco no contrato de seguros é designado risco puro, ou seja, é distinto do risco especulativo, negocial ou financeiro, uma vez que aquele não pressupõe um ganho em uma das pontas da relação jurídica quando da ocorrência de uma perda na outra ponta.

O risco é elemento essencial do contrato de seguros sobretudo por promover a aderência entre as funções econômica e social de que se revestem os seguros: a diluição e o afastamento do possível evento oneroso, mediante sua pulverização e sua compensação econômica. A extinção do risco implica o perecimento do objeto do seguro e a consequente resolução do contrato.

Vera Helena de Mello Franco $^{67}$ ensina que são quatro as características fundamentais do risco: (a) a possibilidade, devendo haver chance realística de o evento ocorrer no plano fático; é com base na possibilidade que se determina, inclusive, a medida

\footnotetext{
65“"La relación entre el sujeto y el objeto ha de ser de naturaleza económica, susceptible de valoración. [...] La naturaleza económica $[\ldots]$ es necesaria porque no basta una naturaleza puramente moral." DONATI, Antigono, op. cit., p. 230.

${ }^{66}$ De acordo com Antigono Donati e Giovanna Volpe Putzolu, os elementos constitutivos do risco são a) a possibilidade; b) de um evento danoso. [...] [...] Não é necessário, contudo, que o evento seja danoso no caso concreto; é suficiente que o dano seja potencial e abstrato, isto é, que o evento seja suscetível de provocá-lo normalmente, segundo a experiência. Nos dizeres dos autores: "Gli elementi costitutivi del rischio sono a) la possibilità; b) di un evento dannoso. [...] Non è necessario, però, che l'evento sia danoso nel caso concreto; è sufficiente che il danno sia potenziale e astratto, cioè, che l'evento sia suscettibile di provocarlo normalmente, secondo l'esperienza." DONATI, Antigono; PUTZOLU, Giovanna Volpe. Manuale di Diritto delle Assicurazioni Private. $3^{\text {a }}$ ed., Milano: Dott. A. Giuffrè Editore, 1987, pp. 124 e 127.

${ }^{67}$ Conforme FRANCO, Vera Helena de Mello, op. cit., p. 302.
} 
e a intensidade do risco (quanto mais uma determinada probabilidade se aproximar da possibilidade, maior o risco); (b) a incerteza, decorrente da inviabilidade de se precisar se o evento irá de fato ocorrer; (c) a licitude, pois o interesse segurável deve ser lícito; e (d) a involuntariedade, que assegura que atos ou fatos voluntários do segurado não sejam passíveis de indenização, exceto quando se tratar de ato praticado em legítima defesa ou em estado de necessidade.

\subsubsection{PRÊMIO E GARANTIA}

Conforme previsto no $\mathrm{CC} / 02$, os elementos prêmio e garantia caminham em paralelo como prestações essenciais das partes no contrato de seguro. Embora os deveres do segurado e da seguradora não se restrinjam ao pagamento do prêmio e à prestação da garantia, respectivamente, são estes os elementos que identificam as principais obrigações que emergem da relação contratual securitária.

Mais do que o pagamento do prêmio, incumbe ainda ao segurado não agravar os riscos, comunicar eventual agravação ou sinistro e o dever de salvamento para minorar o dano, bem como submeter-se à fiscalização da seguradora.

A prestação da seguradora, em contraposição ao que antes dispunha do Código Civil de $1916^{68}$, transcende a simples indenização do dano, envolvendo também o dever de garantir. A noção de garantia introduzida pelo CC/02 introduz a ideia de que a seguradora é capaz de trazer segurança à relação que o segurado mantém com o bem ${ }^{69}$.

Como visto, a prestação da seguradora consiste em prestar garantia, e não somente indenizar. Isto significa que, a fim de honrar sua obrigação de garantir, deve possuir e manter capacidade econômica para fazer frente aos riscos que venham a se materializar ${ }^{70}$.

\footnotetext{
${ }^{68}$ Art. 1.432 do Código Civil de 1.916 - Considera-se o contrato de seguro aquele pelo qual uma das partes se obriga para com a outra, mediante a paga de um prêmio, a indenizá-la do prejuízo resultante dos riscos futuros previstos no contrato.

69“"[...] ao subscrever uma apólice de seguro, o segurado tem em vista não apenas uma soma de dinheiro correspondente à indenização, mas também a garantia de supressão do risco que pesa sobre si; em uma palavra, a segurança." COMPARATO, Fábio Konder, op. cit., p. 136.

70، [...] a obrigação da seguradora surge antes do sinistro, e não com ele. A indenização, deste ponto de vista, é uma obrigação secundária, eventual e condicional, que pode ou não ocorrer. A garantia é uma obrigação constante. [...] A prestação da seguradora é uma prestação de garantia expressa no ônus de formar reservas, antes da ocorrência do sinistro.” Conforme FRANCO, Vera Helena de Mello, op. cit., p. 313.
} 
O dever de indenizar está atrelado a uma série de condicionantes cuja ausência pode eximir a seguradora da sua obrigação de indenizar. São elas: (a) a ocorrência do sinistro nos termos previstos no contrato; (b) a involuntariedade do evento que deu causa ao sinistro; (c) a relação de nexo causal entre o evento e o dano resultante; (d) o cumprimento dos deveres contratualmente pactuados com o tomador do seguro; (e) a comunicação imediata do sinistro; e (f) o dever de salvamento, que impõe que o segurado atue de forma a minorar as consequências do sinistro.

Cumpre lembrar ainda o princípio indenitário que norteia o pagamento das indenizações securitárias, vedando ao segurado obter rendimentos com o dano. Assim, cabe ao segurador avaliar a extensão do dano e, por meio de apreciações matemáticas e estatísticas, determinar o valor devido ao segurado.

Mais do que isso, como ensinam Picard e Besson, o princípio indenitário tem duas finalidades principais: (i) assegurar que não se produzam sinistros voluntários, evitando que os segurados propositalmente provoquem um dano esperando que o montante da indenização securitária exceda o valor do prejuízo decorrente do dano; e (ii) impedir que o seguro seja utilizado como instrumento de aposta ou especulação, i.e., evitar que o segurado especule sobre a materialização de um determinado risco e, diante da possibilidade de vê-lo materializado, contrate uma cobertura em valor elevado esperando que o risco se materialize e que resulte em seu enriquecimento ${ }^{71}$.

Os elementos do contrato de seguros são igualmente indispensáveis a todos os tipos de seguro. Contudo, em virtude de o interesse no seguro de responsabilidade não repousar sobre um bem determinado, mas sobre o patrimônio do segurado como um todo, os elementos interesse e risco ganham alguns contornos especiais nesta modalidade de seguros, como estudado a seguir.

${ }^{71}$ PICARD, M. e BESSON, A., op. cit., p. 291. 


\section{SEGURO DE RESPONSABILIDADE CIVIL}

\subsection{SEGURO DE DANOS}

O seguro de responsabilidade é uma espécie pertencente ao grande grupo dos seguros privados adotado pelo cabedal regulatório brasileiro: os seguros de dano. Genericamente, os seguros de dano são aqueles cujo objeto relaciona-se ao ressarcimento do segurado por uma perda material ou patrimonial.

A função do seguro de dano é de ressarcimento. Sua designação relaciona-se à medida da indenização, a qual é determinada pelo dano patrimonial efetivamente sofrido. Subdividem-se em duas espécies: o seguro de danos diretos ou de coisas e seguro de danos indiretos ou de responsabilidade civil.

Sendo o interesse tutelado material, fala-se em seguro de dano direto, que tem por objetivo cobrir os prejuízos materiais decorrentes da danificação ou perda de uma coisa individualmente determinada que integre ou passe a integrar o patrimônio do beneficiário do seguro.

Em se tratando de interesse imaterial, fala-se em seguro de dano indireto ou de responsabilidade, cujo fito não é resguardar uma coisa determinada que integre o patrimônio do segurado, mas sim o seu patrimônio universalmente concebido na medida em que este se submete ao risco de ser afetado por eventuais ações de terceiros ${ }^{72}$.

A finalidade do seguro de danos indiretos é, portanto, garantir cobertura ao segurado contra os recursos exercidos contra ele por terceiros em decorrência danos a ele deu causa ${ }^{73}$.

\footnotetext{
72، Third party liability insurance is the provision of coverage against either actual or potential damage caused by the insured's personal or professional activity to a third person who is generally not a party to the insurance contract and whose individual existence is not contemplated by the policy at the date of its formulation." PAOLINI, Adolfo; e NAMBISAN, Deepak. Directors and Officers' Liability Insurance. Londres: Informa. 2008, p. 2. Neste mesmo sentido, SÁNCHEZ, Antonio Roncero. El Seguro de Responsabilidad Civil de los Administradores. Revista Para El Análsis Del Derecho, Facultad de Derecho Universidad de Castilla-La Mancha, Bercelona, 2005, p.7.

${ }^{73}$ Conforme Pontes de Miranda: "Seguro de responsabilidade - dito, frequentemente, seguro de responsabilidade civil, para se distinguir da responsabilidade penal - é o seguro contra o risco de ser responsável a ressarcir danos. O segurador vincula-se a prestar ao segurado aquilo que esse tenha de prestar a
} 
Importante salientar que, não obstante um mesmo ato do administrador ter o condão de ensejar mais de um tipo de responsabilidade, podendo o seguro de responsabilidade civil cobrir também a responsabilidade administrativa e algumas das excepcionais responsabilidades objetivas imputáveis ao administrador, havendo dolo, não há que se falar em cobertura securitária em qualquer seara.

A este respeito, Pontes de Miranda coloca que, de fato, pode haver sobreposição das responsabilidades civil e penal, hipótese em que não convém apreciar os efeitos de tal coincidência, mas sim aferir a segurabilidade do ato:

Quanto ao problema da responsabilidade civil que coincide com a responsabilidade criminal, não se pode, a priori, dizer que aquela não é segurável. Convém que se evitem assimilações e apreciações da coincidência. O que se tem de verificar somente concerne ao risco da responsabilidade dita civil. Não importa o que coincide ou em que a responsabilidade civil coincide com a responsabilidade criminal. No tocante ao seguro de responsabilidade, a atividade dolosa - positiva ou negativa - é que é insegurável ${ }^{74}$.

Assim, a regra geral que vigora é a de que, se um mesmo ato ensejou responsabilização simultaneamente nos âmbitos civil e penal, não deve haver cobertura securitária em nenhum dos âmbitos.

\subsection{PARTICULARIDADES DO SEGURO DE RESPONSABILIDADE}

\subsubsection{DA GARANTIA E SEUS LIMITES}

Os seguros de dano têm por objetivo assegurar o pagamento de indenização ao segurado por prejuízos devidamente comprovados, que acarretaram perdas e/ou danos aos bens segurados.

terceiro (capital, interesse, despesas)." MIRANDA, Francisco Cavalcanti Pontes de, Teoria de Direito Privado - Direito das Obrigações: contrato de seguro, Campinas, Bookseller, v. 47, 2006, p. 87. Neste mesmo sentido, vide GASPERONI, Nicola. Assicurazioni Private. Padova: Casa Editrice Dott. Antonio Milani, 1972, p. 454.

${ }^{74}$ MIRANDA, Francisco Cavalcanti Pontes de, op. cit., p. 91. 
Embora o objetivo da grande maioria dos seguros (exceção feita a alguns tipos de seguros de pessoas, como o seguro de vida e seguro contra acidentes pessoais) seja ressarcir os segurados de eventuais danos dentro dos limites da apólice, o propósito do seguro de responsabilidade difere dos demais na medida em que se destina a garantir a totalidade do patrimônio do segurado até um valor máximo. Estes seguros garantem o pagamento ao segurado de um montante incerto, o qual se limita a uma quantia máxima estipulada à época da contratação do seguro.

Por operar desta forma, Picard e Besson referem-se a este seguro como "seguro de responsabilidade sobre objeto indeterminado", pois, em não sendo possível antecipar quais os sujeitos lesados pelo segurado, nem tampouco a extensão dos danos a eles causados, as consequências das responsabilidades sobre o patrimônio do segurado (i.e., o objeto do seguro) não podem ser calculadas de antemão. Daí a razão da indeterminação de seu objeto $^{75}$.

Como ensina Priscila M. P. Corrêa Fonseca, em virtude desta característica, o valor do risco no ato da contratação do seguro é apenas estimado:

O valor do risco por ocasião do seguro é apenas estimado e não avaliado. A apuração dar-se-á tão somente no momento da ocorrência do sinistro. É que, se a avaliação se der ao ensejo da contratação do seguro, poderá, quando do sinistro, mostrar-se inadequada. ${ }^{76}$

Equivale a dizer que, não obstante a apólice prever o pagamento, pela seguradora, de um valor máximo previamente pactuado entre ela e o beneficiário quando da verificação dos eventos indenizáveis nos termos da apólice, o valor efetivo da indenização é desconhecido das partes no momento da contratação e somente poderá ser aferido quando da efetiva ocorrência do dano ${ }^{77}$.

\footnotetext{
${ }^{75}$ PICARD, M. e BESSON, A.. op. cit, p. 287.

${ }^{76}$ FONSECA, Priscila M. P. Corrêa. Contrato de Seguro. In Contratos Nominados - Doutrina $e$ Jurisprudência. Ed. Saraiva, 1995, pp. 441-457.

${ }^{77}$ Neste sentido, Adolfo Paolinin e Deepak Nambisan afirmam que "Although parties will almost always fix the maximum recoverable sum [...], the exact amount of the actual payment falls to be ascertained at the time of the loss." PAOLINI, Adolfo e NAMBISAN, Deepak, op. cit., pp. 1-2.
} 


\subsubsection{DO INTERESSE SEGURÁVEL}

$\mathrm{O}$ interesse segurável relaciona-se ao objeto do contrato de seguro ${ }^{78}$. Embora a noção primária do objeto do contrato de seguro estivesse associada à proteção ao segurado contra perda ou destruição de coisas materiais existentes em seu patrimônio, esta concepção ora recepcionada pelo Código Civil de 1916 foi superada pelo CC/02, o qual trata o objeto do seguro como garantia a um interesse legítimo.

No seguro de danos diretos, o interesse segurável repousa sobre um bem isolado que compõe o patrimônio do segurado. No seguro de danos indiretos, recai sobre o patrimônio total do segurado, e não a seus componentes isolados. O interesse segurável assenta-se, neste caso, na conservação da integralidade do patrimônio sujeito à diminuição em virtude do risco a que é exposto. Não se trata de seguro de um bem específico, mas sim de seguro ao patrimônio do contratante universalmente considerado ${ }^{79}$.

Em outras palavras, o interesse segurável em matéria de seguro de responsabilidade civil consiste em evitar que se produza um dano a um patrimônio em decorrência da responsabilização do titular de tal patrimônio pela produção de outro dano (aquele sofrido por terceiro). Existirá interesse, portanto, sempre que o segurado possa vir a ser obrigado a responder com seu patrimônio ${ }^{80}$.

Outra importante particularidade do interesse segurável no seguro de responsabilidade civil é a forma de determinação do valor a ser atribuído ao interesse. Nos seguros de danos diretos, a determinação do prêmio e a medida da indenização levam em conta valor da coisa segurada e os possíveis danos a que ela se sujeita.

Já nos seguros de danos indiretos, a estimativa do valor do interesse segurado e da extensão dos prejuízos a que o interesse é exposto são mais complexas. Considerando que o interesse segurável busca evitar um dano a uma universalidade, fixa-se uma quantia correspondente ao valor segurado. O prêmio e a medida da indenização do seguro de

\footnotetext{
${ }^{78}$ Conforme COMPARATO, Fábio Konder, op. cit., p. 23.

${ }^{79}$ Neste mesmo sentido, Pontes de Miranda, ao tratar dos seguros de responsabilidade civil, afirma que: "Não se há de pensar em seguro de coisa, e sim em seguro de patrimônio." MIRANDA, Francisco Cavalcanti Pontes de, op. cit., v. 47, pp. 85-86.

${ }^{80}$ "En el seguro de la responsabilidad civil existe un interés asegurable toda vez que el asegurado deba o pueda deber responder por el hecho suyo o de um tercero.” HALPERIN, Isaac, op. cit., v.2, p. 780.
} 
responsabilidade são calculados com base no valor atribuído ao interesse, ficando tal valor ainda restrito à responsabilidade derivada de certos $\operatorname{atos}^{81}$.

Isto não afasta, entretanto, a proporcionalidade entre o prejuízo sofrido, o valor segurado e o valor da indenização. Ou seja, não se pode atribuir um valor aleatório ao interesse segurável somente pelo fato de o interesse não recair sobre uma coisa determinada do patrimônio do segurado, sob pena de se macular a validade do contrato por violação ao princípio indenitário.

\subsubsection{DO MOMENTO DO SINISTRO}

Como mencionado no item anterior, as variantes que orbitam em torno do objeto do seguro de responsabilidade guardam relação direta com o momento em que se verifica a materialização do sinistro.

Vera Helena de Mello Franco deparou-se com alguns entraves quanto ao fato gerador do dever de indenizar da seguradora, mais precisamente, o sinistro. De acordo com a autora, há três correntes de pensamento acerca do tema, segundo as quais o gatilho do sinistro será (i) o fato físico ou moral danoso para a vítima e causador do dano futuro ao segurado; (ii) o fato jurídico representado pela reclamação do segurado; e (iii) o fato jurídico representado pelo cumprimento da obrigação do segurado frente ao terceiro lesado $^{82}$.

A primeira defende que a simples ocorrência do fato danoso, antes mesmo de qualquer reclamação do segurado, já configura o início do sinistro. A favor desta primeira corrente, advoga Nicola Gasperoni, afirmando que o sinistro se verifica no momento em que surge o dano para o terceiro, dano este que resulta na responsabilização do segurado e que faz nascer a obrigação da seguradora de indenizar ${ }^{83}$.

\footnotetext{
${ }^{81}$ “En el seguro de la responsabilidad, dado que cubre todo el patrimonio contra la responsabilidad que puede contraerse respecto de un tercero, su límite no resulta en relación a una cosa o bien determinado, sino por la fijación de cierta suma y su restricción a la responsabilidad derivada de ciertos hechos." HALPERIN, Isaac, op. cit., v.2, pp. 792-793.

${ }^{82}$ Conforme FRANCO, Vera Helena de Mello, op. cit., pp. 325-326.

${ }^{83}$ Conforme GASPERONI, Nicola, op. cit., p. 463.
} 
Como visto, nem todo dano a terceiro obrigatoriamente implicará responsabilização do segurado (em verdade, o dano a terceiro somente se torna um embrião de sinistro quando o terceiro opta por demandar o segurado), nem tampouco fará surgir necessariamente a obrigação à seguradora, pois, em regra, a seguradora não indeniza o dano sofrido pelo terceiro em si, e sim o segurado que comunicou uma reclamação de terceiro.

Os adeptos da segunda teoria enxergam a concretização do sinistro somente a partir da ação de ressarcimento, da reclamação de caráter judicial ou extrajudicial dirigida contra o segurado. Pedro Alvim é um dos seguidores a segunda teoria:

Durante muitos séculos, vigorou somente o seguro marítimo onde os riscos cobertos têm sempre um efeito nocivo e adverso para a navegação. [...] Todavia, com a expansão da atividade seguradora para os riscos terrestres e os de pessoa, surgiram coberturas de eventos que nem sempre importavam num acontecimento infeliz ou num infortúnio. [...] Sinistro é apenas a realização do acontecimento previsto no contrato, independentemente de suas consequências. Enquanto não ocorre, o risco é um evento incerto, seja quanto à sua realização, seja quanto ao tempo de sua ocorrência. Quando deixa de ser incerteza para transformar-se numa realidade fática muda de nome; passa a denominar-se sinistro ${ }^{84}$.

De fato, como explica Pedro Alvim, ainda que os efeitos do acontecimento (sinistro) previsto no contrato - no caso do seguro de responsabilidade civil, a reclamação de terceiro supostamente lesado - não culminem com a efetiva condenação do administrador, em teoria, a simples ocorrência do acontecimento (ser o administrador demandado por terceiro) já configura o sinistro.

Como tal, contanto que o segurado observe seus deveres nos termos do contrato, o sinistro já cria para a seguradora a obrigação de indenizar, adiantando os custos de defesa em benefício do administrador envolvido.

Nesta mesma linha, Isaac Halperin coloca que o mero nascimento, para a vítima, de um direito a indenização não importa dano concreto ao segurado, haja vista que, a menos

\footnotetext{
${ }^{84}$ Conforme ALVIM, Pedro, O Contrato de Seguro, 3 a ed., Rio de Janeiro: Forense, 1999, pp. 393-394.
} 
que a vítima reclame a indenização, do ponto de vista do seguro, existirá somente um prejuízo patrimonial potencial ${ }^{85}$.

Os partidários da terceira corrente, por fim, consideram que o sinistro é composto por diversas etapas que se iniciam com a ocorrência do fato danoso e se materializa com a declaração da responsabilidade. Neste último caso, ter-se-ia, na verdade, dois danos: o material ou moral, causado ao terceiro pelo ato do segurado, e o jurídico, representado pela reclamação.

O evento físico ou moral, por si só, não parece ser lesivo ao patrimônio do segurado, motivo pelo qual não representaria, de imediato, um sinistro. Por outro lado, se a determinação do sinistro dependesse do reconhecimento da responsabilidade, no caso de restar provado que não houve efetiva responsabilidade do segurado, os recursos despendidos com sua defesa não teriam guarida do seguro.

"Das diversas teorias", coloca Vera Helena de Mello Franco, "a mais adequada seria a que vê o seguro de responsabilidade civil como um fato complexo ${ }^{86 "}$.

De fato, a teoria que se afigura a mais correta é aquela que encara o sinistro como um fato complexo, não como um ato isolado. No entanto, para fins práticos, é mister precisar o momento exato que consagra o sinistro. Assim sendo, a segunda teoria parece ser a mais adequada do ponto de vista prático, pois leva em conta os desdobramentos do ato danoso, sem deixar de resguardar o patrimônio do segurado desde logo (i.e., dispêndios com custos de defesa).

\subsubsection{DA DELIMITAÇÃO TEMPORAL}

Adicionalmente aos obstáculos que se impõem à delimitação do objeto do seguro e do sinistro, em matéria de seguro de responsabilidade, uma terceira dificuldade se coloca: o prazo do seguro, vis-à vis a perpetuação do risco no tempo.

\footnotetext{
${ }^{85}$ HALPERIN, Isaac. op. cit., v.2, pp. 850-851. Picard e Besson corroboram este entendimento ao afirmarem que o sinistro não se materializa quando da ocorrência do dano à vítima, mas sim no momento em que esta última se volta contra o segurado, seja mediante uma reclamação, seja mediante a proposta de um acordo amigável. PICARD, M. e BESSON, A., op. cit., p. 287.

${ }^{86}$ Conforme FRANCO, Vera Helena de Mello, op. cit., p. 326.
} 
Os seguros, em sua maioria, destinam-se a cobrir riscos de rápida materialização, isto é, aqueles nos quais se verifica o ato danoso tão logo ocorra o sinistro. No entanto, algumas espécies específicas, como é o caso do seguro de danos indiretos, a ocorrência do dano não caracteriza, por si só, o sinistro, sendo necessária uma reclamação decorrente do dano para que referido sinistro seja configurado.

Visando a atender ambas as situações, o direito norte-americano introduziu duas modalidades de cobertura relativas aos seguros de responsabilidade: coberturas à base de ocorrência (occurence basis) ou à base de reclamação (claims-made basis).

As primeiras contemplam os riscos de rápida materialização, que tenham ocorrido e sido notificados à época da vigência da apólice. Já as apólices que oferecem cobertura à base de reclamação, por compreenderem os riscos de longa exposição, estão condicionadas à existência de uma reclamação referente ao dano a terceiro para que o sinistro seja configurado. Desta forma, contanto que a reclamação referente ao dano seja realizada durante a vigência da apólice, tal cobertura deverá incluir os danos ocorridos anteriormente e no decorrer da vigência da apólice.

Estas distinções foram recepcionadas pela regulamentação brasileira por meio da Circular da Superintendência de Seguros Privados (“SUSEP”) n 336/07"87, conforme alterada, levando em conta justamente a questão cronológica que envolve o risco e o objeto do seguro.

As apólices à base de ocorrências definem o objeto do seguro como o pagamento e/ou o reembolso das quantias, respectivamente, devidas ou pagas a terceiros, pelo segurado, a título de reparação de danos, estipuladas por tribunal civil ou por acordo aprovado pela sociedade seguradora, contanto que: (a) os danos tenham ocorrido durante o período de vigência da apólice; e (b) o segurado pleiteie a garantia durante a vigência da apólice ou nos prazos prescricionais em vigor.

\footnotetext{
${ }^{87}$ Conforme Anexo I à Circular SUSEP 336/07, Art. $1^{\text {o }}$ - As apólices à base de reclamações constituem alternativa para a contratação de seguros de responsabilidade civil, em modalidades sujeitas a risco de latência prolongada ou a sinistros com manifestação tardia.
} 
Já as apólices à base de reclamações definem como objeto do seguro, o pagamento e/ou o reembolso das quantias, respectivamente, devidas ou pagas a terceiros, pelo segurado, a título de reparação de danos, estipuladas por tribunal civil ou por acordo aprovado pela seguradora, desde que: (a) os danos tenham ocorrido durante o período de vigência da apólice ou durante o período de retroatividade; e (b) o terceiro apresente a reclamação ao segurado (i) durante a vigência da apólice; ou (ii) durante o prazo complementar, quando aplicável; ou (iii) durante o prazo suplementar, quando aplicável.

O prazo complementar consiste no período adicional para a apresentação de reclamações ao segurado, por parte de terceiros, concedido, obrigatoriamente, pela seguradora, sem cobrança de qualquer prêmio adicional, tendo início na data do término de vigência da apólice ou na data de seu cancelamento.

O prazo suplementar, por sua vez, consiste no prazo adicional ao prazo complementar, obrigatoriamente, pela seguradora, mediante a cobrança facultativa de prêmio adicional, tendo início na data do término do prazo complementar.

Cumpre salientar que estes prazos não implicam alteração da vigência do contrato de seguro. O prazo adicional previsto nestes dispositivos refere-se ao período para apresentação da reclamação de terceiro, não de duração do contrato.

Estas delimitações temporais são necessárias porque, do contrário, a seguradora ficaria indefinidamente sujeita a garantir o patrimônio do segurado contra reclamações de terceiros ${ }^{88}$.

O conjunto de particularidades do seguro de responsabilidade civil faz dele um instrumento de funcionamento altamente complexo, pois, como visto, é mais dificultosa a determinação do momento exato da ocorrência do sinistro e a quantificação do risco (que é apenas estimado, não avaliado).

\footnotetext{
${ }^{88}$ “Na prática, porque pode o terceiro não exigir, desde logo, o que se lhe deve, é permitida a cláusula de tempo máximo, findo o qual a dívida do segurador se extingue. Aliás, se houve o fato e o terceiro não pede o ressarcimento, o contraente pode exigir do segurador o depósito." MIRANDA, Francisco Cavalcanti Pontes de, op. cit., v. 47, p. 86.
} 
Ademais, a perpetuação do risco no tempo e a complexidade no processo de apuração da responsabilidade do segurado também impactam a cobertura securitária. Estas e outras particularidades do seguro de responsabilidade civil de administradores frequentemente afetam a aplicabilidade do seguro, pois a atividade gestacional não pressupõe um ato isolado e estanque.

A administração, sobretudo no âmbito do mercado de capitais, envolve uma cadeia de atos realizados em um determinado período por diversos administradores, cujos efeitos muitas vezes somente são verificados tempos após sua realização. Por este motivo, nem sempre é possível pinçar o ato específico que ocasionou o dano, nem tampouco determinar sua autoria e a efetiva contribuição do agente para a ocorrência do dano.

Conforme examinar-se-á oportunamente, este conjunto de fatores pode tornar discutível a aplicabilidade do seguro de responsabilidade civil no contexto da administração das companhias, haja vista que o seguro envolve uma série de pressupostos de difícil aferição, tais como comunicação de atos ou fatos capazes de ocasionar o dano (como visto acima, nem sempre é possível precisar o ato causador do dano e seu agente) e inexistência de dolo. 


\section{SEGURO DE RESPONSABILIDADE CIVIL DE ADMINISTRADORES}

\subsection{HISTÓRICO}

O seguro de responsabilidade civil de administradores teve origem na década de 30 com a quebra da Bolsa de Valores de Nova Iorque em 1929, momento em que diversos acionistas, diante da desvalorização de suas ações, buscavam o ressarcimento de suas $\operatorname{perdas}^{89}$.

A fim de atender à crescente demanda por mecanismos destinados à minimização das perdas dos investidores, o Loyds Underwriters (London) criou um novo seguro destinado a assegurar o patrimônio dos administradores, garantindo que tivessem recursos suficientes para fazer frente aos custos de defesa e indenização decorrentes de demandas iniciadas por investidores ou outros terceiros.

Originalmente, este seguro não atraiu grande contingente de investidores. A procura por este tipo de cobertura somente se intensificou entre os anos de 1960 e 1970, período que sucedeu o pós-guerra e consolidou a economia norte-americana, atraindo novamente os investimentos em bolsa.

O mesmo ocorreu ao final dos anos 90 e início do século XXI, época em que os escândalos corporativos envolvendo empresas norte-americanas como a Enron Corporation e a WordCom estimularam fortemente a busca por seguros de responsabilidade civil de administradores $^{90}$.

\footnotetext{
${ }^{89 ،} \mathrm{O} D \& O$ Insurance teve sua origem na crise bolsista de 1929. Muitos accionistas prejudicados com a queda do valor de suas acções e com a falência das sociedades em que haviam investido pretendiam ser indenizados dos danos sofridos. [...] Foi neste quadro que, nos anos trinta, foi criado pela Loyds Underwriters (London) um novo seguro, o $D \& O$ Insurance, para a cobertura das responsabilidades dos directors e dos outros officers perante os accionistas. De início, este seguro não teve êxito nem expansão assinalável no mercado. Só nos anos sessenta e setenta do século $\mathrm{XX}$ o $D \& O$ Insurance veio a ter um acréscimo de procura em consequiência de um aumento da litigiosidade contra os administradores." VASCONCELOS, Pedro Pais de, $D \& O$ INSURANCE: O Seguro de Responsabilidade Civil dos Administradores e outros Dirigentes da Sociedade Anónima, Ed. Almedina, 2007, p. 13.

${ }^{90}$ FIER, Stephen et al. averiguaram que grandes escândalos corporativos implicavam perdas impactantes que, consequentemente, afetavam diretamente o comportamento dos preços do seguro. Mediante uma análise empírica, constataram que o nível de cobertura de seguro contratado pelas companhias aumentava proporcionalmente à probabilidade de exposição à responsabilidade civil. Nas palvras dos autores: "We find
} 
Confira-se nas palavras de Antonio Roncero Sánchez:

A evolução do número de reclamações buscando responsabilidade contra administradores de sociedades de capital e o aumento do valor das indenizações que devem ser satisfeitas como consequência de transações ou decisões judiciais, assim como os acontecimentos recentes de grande transcendência para o setor de seguros (ataques terroristas de 11 de Setembro de 2001, escândalos financeiros de multinacionais norteamericanas como Enron ou WorldCom) provocaram perdas muito importantes neste ramo de seguro e, com ele, uma nova convulsão na oferta desta modalidade assegurativa. ${ }^{91}$ (tradução livre)

No Brasil, o seguro foi introduzido em meados dos anos 90, motivado sobretudo pelo crescente número de companhias brasileiras que começaram a negociar $\mathrm{ADRs}^{92}$ (American Depositary Receipts) nas bolsas norte-americanas ${ }^{93}$. Como nos Estados Unidos da América são bastante frequentes as demandas provenientes de acionistas (vide seção 6.1.2), tais companhias optaram por adquirir este seguro.

A propósito do incremento nos seguros de responsabilidade, Ernesto Tzirulnik, ao traçar a evolução histórica da responsabilidade civil, constatou que seu aprimoramento ao curso dos tempos não impediu que o instituto atingisse um ponto de estagnação.

that the scandal-based events were unique loss shocks that directly impacted insurer pricing behavior. [...] In particular, as the likelihood of $\mathrm{D} \& \mathrm{O}$ liability exposure increases, insurance purchasing firms increase their level of insurance coverage." FIER, Stephen G., MCCULLOUGH, Kathleen A. GABEL, Joan T. A. e MANSFIELD, Nancy R. The Directors and Officers Insurance Marketplace: An Empirical Examination of

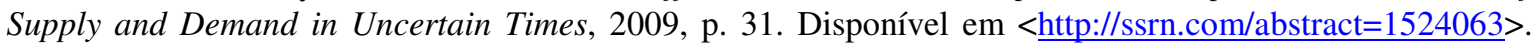
Acesso em 15.10.2012.

${ }^{91}$ Nos dizeres do autor: "La evolución del número de reclamaciones en exigencia de responsabilidad contra administradores de sociedades de capital y el aumento de la cuantía de las indemnizaciones que han de ser satisfechas como consecuencia de transaciones o de resoluciones judiciales, así como acontecimentos recentes de gran transcendência para el sector assegurador (ataques terroristas del 11 de Septiembre de 2001, escándalos financieros de multinacionales estadounienses como Enron o WorldCom) han provocado perdidas muy importantes em este ramo del seguro y com ello una nueva cónvulsion en la oferta de esta modalidade asegurativa [...]." SÁNCHEZ, Antonio Roncero, op. cit., p. 3.

${ }^{92} \mathrm{Na}$ definição do Banco Central do Brasil, ADRs são "certificados representativos de ações ou de outros valores mobiliários que representam direitos e ações, emitidos no exterior por instituição denominada depositária, com lastro em valores mobiliários de emissão de empresas brasileiras depositados em custódia específica no Brasil." Disponível em <www.bcb.gov.br>. Acesso em 15.10.2012.

93، O D\&O chegou ao Brasil em meados da década de 1990, quando as empresas começaram a lançar American Depositary Receipts (ADRs) nos Estados Unidos. Como lá a legislação é bem mais rígida, era recomendável, além de prudente, ter o seguro. A Companhia Siderúrgica Tubarão (CST) foi uma das pioneiras a contratar apólices de responsabilidade civil, em 1995." VAMPEL, Daniella. Melhor Prevenir, in Revista Capital Aberto, no 9, ano 1, maio/2004, p. 42. 
Para o autor, tal estagnação decorreu não tanto de falhas conceituais, mas da mera “incapacidade de todo e qualquer instituto jurídico de promover a reparação econômica, especialmente no mundo contemporâneo, na chamada 'civilização do risco', que, sem embargo das crescentes técnicas e políticas de prevenção, produz até mesmo danos que jamais os patrimônios individuais seriam capazes de suportar, sequer os mais valedouros." 94

Isto explica, em parte, o porquê da crescente demanda por seguro de responsabilidade. A insuficiência do respaldo jurídico conferido pelo direito da responsabilidade para resguardar os direitos que emergem da responsabilização civil (aqui relevadas eventuais ineficiências do ordenamento pátrio e consideradas somente as limitações patrimoniais do agente ao qual incumbe o dever de reparar dano) justificaria, portanto, a busca por guarida no direito securitário ${ }^{95}$.

\subsection{REGULAMENTAÇÃO}

A regulamentação pátria recepcionou esta modalidade de seguro como "Seguro de Responsabilidade Civil de Administradores e Diretores - D\&O”, incluindo-o na categoria geral de "seguros de responsabilidade" e atribuindo a ele classificação em ramo próprio $(\text { ramo } 10)^{96}$.

No Brasil, é um seguro comumente contratado pela pessoa jurídica, tendo como beneficiários os indivíduos que exercem funções gerenciais ou influenciam o processo decisório relativo aos rumos e negócios da entidade em questão.

De acordo com seguradoras locais, são duas as razões primordiais que motivam a contratação do seguro pela pessoa jurídica e não pelo indivíduo segurado: (i) o seguro de responsabilidade civil de administradores é precificado, dentre outras variáveis, com base

\footnotetext{
${ }^{94}$ TZIRULNIK, Ernesto, O Futuro do Seguro de Responsabilidade Civil, in Doutrinas Essenciais Responsabilidade Civil: Direito das Obrigações e Direito Negocial (org. Nelson Nery Junior e Rosa Maria de Andrade Nery), $2^{\mathrm{a}}$ ed., São Paulo: Revista dos Tribunais, 2010, p. 718.

95“"Com efeito, entre as técnicas privadas, o seguro e a previdência despontam como as únicas capazes de prover as indenizações de dimensões compatíveis com os efeitos da infortunística moderna." Ernesto Tzirulnik, op. cit., p. 720.

${ }^{96}$ Conforme Circular SUSEP no 395 de 3 de dezembro de 2009, Anexo I - Tabela de Ramos e Grupos aplicáveis às operações de seguros.
} 
no faturamento da pessoa jurídica (e não no histórico do executivo beneficiário da cobertura); e (ii) a rotatividade dos cargos de comando dificultaria a operacionalização do seguro, sobretudo nas companhias de grande porte; por isso, instituiu-se uma forma de contratação que evita que a saída de executivos dos cargos que ocupam e alterações nos quadros administrativos não impactam os seguros.

Embora a SUSEP tenha determinado o enquadramento do seguro de responsabilidade civil de administradores em uma categoria específica, esta modalidade de seguro não possui regras próprias, seja na legislação, seja nos diplomas infralegais. As condições mínimas que amparam a contratação e funcionamento deste seguro são as regras gerais aplicáveis às apólices à base de reclamações e as circulares da SUSEP que disciplinam a operacionalização das apólices de seguro de responsabilidade civil à base de reclamações ${ }^{97}$.

\subsection{CARACTERÍSTICAS DO SEGURO}

\subsubsection{TOMADOR E BENEFICIÁRIO}

O tomador do seguro de responsabilidade civil de administradores é, em regra, a pessoa jurídica (sociedade empresária, fundação ou associação) cuja gestão compete aos administradores beneficiários do seguro por ela contratado, incumbindo a ela o pagamento do prêmio, a manutenção e gerenciamento da apólice.

Como a regulamentação não prevê um rol taxativo de pessoas elegíveis à categoria de segurado, podem figurar como beneficiários todas as pessoas que de alguma forma tenham ingerência nos negócios sociais, que estejam envolvidas com a tomada de decisão pela sociedade ou que realizem representação de fato da sociedade tomadora e suas subsidiárias, motivo pelo qual poderiam ser demandadas por terceiros.

Destarte, os beneficiários do seguro de responsabilidade civil de administradores podem abranger diretores não estatutários, gerentes, supervisores, procuradores e empregados que desempenhem funções gerenciais.

\footnotetext{
${ }^{97}$ Circular SUSEP n 336 de 22 de janeiro de 2007, conforme alterada pela Circular SUSEP no 348 de 1 de agosto de 2007.
} 
Vale lembrar ainda que, em virtude da natureza da apólice à base de reclamações (vide seção 4.2.4), é possível que sejam abrangidos pela cobertura não apenas os administradores investidos de seus cargos no momento da contratação do seguro, mas também os administradores que ocuparam tais cargos e os que futuramente vierem a fazêlo durante a vigência da apólice.

\subsubsection{GARANTIAS E COBERTURA}

O seguro de responsabilidade civil de administradores tem por objeto o pagamento das quantias relativas a (i) custos de defesa dos segurados, em processos administrativos e/ou judiciais, decorrentes de ato regular de gestão; e (ii) indenização de prejuízos sofridos por terceiros, pelos quais os segurados venham a ser responsabilizados.

O pagamento dos custos de defesa já foi alvo de críticas sob a alegação de que tais custos não consistem em um dano material derivado do ato, mas sim em um gasto do interesse do próprio administrador.

Isaac Halperin, entretanto, esclarece que não se trata de indenização dos danos, mas sim de valores despendidos a título de salvamento. Tanto é verdade que tais gastos se destinam a evitar o dano que eles também são reembolsados quando a pretensão do terceiro é rechaçada: trata-se de um gasto idôneo para evitar o dano ${ }^{98}$.

Dentro da vigência da apólice e dos prazos regulamentares adicionais, são cobertas pela apólice (a) as reclamações de que o segurado tome conhecimento durante o período de vigência do seguro, referentes a fatos ou circunstâncias ocorridos entre a data limite de retroatividade (para fins dos danos ocorridos anteriormente à vigência da apólice) e o término do período de vigência do seguro; e (b) as reclamações futuras - recebidas após o término do período de vigência do seguro - relacionadas a fatos ou circunstâncias que tenham sido notificados à seguradora durante o período de vigência do seguro.

\footnotetext{
${ }^{98}$ In verbis: "[Los gastos] no se resarcen o reembolsan como daños, sino como gastos de salvamento; [...] Este concepto, de que se trata de gastos para reducir o evitar el daño, conduce a imponer el reembolso también cundo la pretensión del tercero es rechazada: es un gasto idóneo para evitarlo." HALPERIN, Isaac, op. cit, v.2, p. 646-647.
} 
Desta forma, uma vez acionado o seguro, em princípio, deverá o administrador ser ressarcido dos custos incorridos na defesa de uma reclamação, tais como honorários advocatícios e despesas processuais, bem como dos valores referentes à reparação dos danos que seja legalmente obrigado a pagar, por força de condenações transitadas em julgado, decisões administrativas, acordos judiciais e extrajudiciais aprovados pela seguradora, sentenças proferidas por tribunais arbitrais, dentre outros.

Dependendo da forma de contratação, o administrador poderá receber a indenização diretamente da seguradora ou da própria companhia, sendo esta última reembolsada pela seguradora na sequência. No primeiro caso, trata-se da chamada Cobertura A; no segundo, Cobertura $B^{99}$. Ainda que se fale em coberturas de tipos distintos, frise-se que se trata de um mesmo risco; o que muda é apenas a forma como a indenização securitária é paga.

A cobertura do seguro não se aplica (i) se houver dolo ou culpa grave do segurado $^{100}$; e (ii) nas hipóteses de exclusão de cobertura expressamente previstas na apólice, conforme discutidas no capítulo sobre aplicabilidade do seguro. Neste diapasão, o reconhecimento da culpa em sentido lato (dolo ou culpa) depende de decisão transitada em julgado. Até que advenha a decisão, em regra, os custos de defesa são pagos pela seguradora; proferida a sentença e comprovado o dolo do segurado, tais custos deverão ser por ele restituídos à seguradora.

Vale observar que a responsabilidade amparada pela cobertura deste seguro é somente aquela que decorre do exercício das funções próprias da administração da sociedade, não podendo ser abrangidas pelo seguro outras atividades que não guardem relação direta com a gestão da companhia.

\footnotetext{
99“ $\mathrm{Na}$ primeira hipótese [Cobertura A], a seguradora indenizará diretamente o administrador pelos valores que ele tenha despendido com custos de defesa ou condenações pecuniárias, relativos a eventos cobertos pelo seguro e desde que tais não tenham sido previamente pagos ao administrador pela empresa tomadora. $\mathrm{O}$ segundo caso [Cobertura B] refere-se à situação em que a empresa tomadora tenha adiantado ao administrador o reembolso desses custos de defesa ou condenações pecuniárias, mediante prévia e expressa autorização da seguradora." FARIA, Clara Beatriz Lourenço de. O seguro D\&O como instrumento de proteção patrimonial dos administradores de sociedades limitadas e anônimas. Monografia de Pós Graduação - Insper - Instituto de Ensino e Pesquisa: São Paulo, 2010.

${ }^{100}$ Conforme art. 762/CC e art. 22 da Circular SUSEP n ${ }^{\circ} 256$ de 16 de junho de 2004.
} 
Este seguro também não se confunde com o seguro de responsabilidade civil profissional $^{101}$, assim entendido o seguro destinado à proteção do profissional liberal (como médico, advogado, contabilista) por erro, omissão ou descumprimento do dever incorrido no exercício da especialidade segurada.

O desempenho de atividades gerenciais não consiste no exercício de uma profissão propriamente dita. Inclusive, na prática, os indivíduos que ocupam cargos de gestão possuem diversas formações acadêmicas. O termo "profissão", pois, não pode ser confundido com o termo "profissionalismo", conquanto a gestão de uma companhia exija elevado grau de profissionalismo.

Ademais, a contratação de seguro de responsabilidade civil profissional é condicionada à apresentação da habilitação para o exercício da especialidade objeto do seguro no interesse de terceiros. A manutenção do cargo de administrador, como se sabe, não só independe de uma habilitação específica, como é exercida pelo administrador no interesse da companhia, e não de terceiros de um modo geral ${ }^{102}$.

\subsubsection{SELEÇÃO DE RISCOS}

Em princípio, a determinação dos riscos segurados decorre da vontade das partes contratantes $^{103}$. As partes são livres para avençar os riscos a serem garantidos pela apólice, observados os limites legais e regulatórios (e.g., impossibilidade de cobertura de atos dolosos), a cobertura mínima e as especificidades aplicáveis a cada ramo de seguros.

Para facilitar o processo seletivo de riscos, J. Efrén Ossa G. propõe subdividi-los em riscos objetivos e subjetivos ${ }^{104}$. Os primeiros devem ser entendidos como os riscos tangíveis, passíveis de ser identificados com o uso dos sentidos e que geralmente se materializam independente da vontade do indivíduo ${ }^{105}$.

\footnotetext{
${ }^{101}$ Conforme SÁNCHEZ, Antonio Roncero, op. cit., p. 8.

${ }^{102}$ Conforme PAOLINI, Adolfo; e NAMBISAN, Deepak, op. cit., p. 15.

${ }^{103}$ Conforme PICARD, M. e BESSON, A., op. cit., p. 301.

${ }^{104}$ OSSA G., J. Efrén, op. cit., pp. 76-77.

${ }^{105}$ Neste mesmo sentido, vide PICARD, M. e BESSON, A., op. cit., p. 37.
} 
A título ilustrativo, em um contrato de seguro contra incêndio de um prédio, o risco objetivo será avaliado mediante análise das propriedades físicas e das condições do bem segurado (material de que é feito o prédio, possibilidade de combustão dos objetivos mantidos em seu interior, área em que se localiza o prédio, entre outros).

Assim, pode-se inferir que, por serem palpáveis, os riscos objetivos permitem uma maior previsibilidade do risco. Em certa medida, é possível antever os acontecimentos que, dadas as características do bem segurado, o meio em que ele se encontra e as circunstâncias informadas pelo segurado, possam vir a avariá-lo.

Os riscos subjetivos, por sua vez, são o conjunto de qualidades psíquicas e comportamentais inerentes à pessoa do segurado e que podem interferir positiva ou negativamente na ocorrência do sinistro. Como há limitações para prever e avaliar os atributos pessoais do segurado, a mensuração e a previsibilidade dos riscos subjetivos são, em comparação aos riscos objetivos, mais dificultosas para as seguradoras.

No caso dos seguros de responsabilidade, uma das maiores dificuldades reside justamente na porção subjetiva do risco. Embora os riscos objetivos também possam ser bastante variados, dependendo inclusive do tipo de atividade que a companhia desenvolve (e.g., uma produtora química tem maiores chances de ser reclamada por danos ambientais), estes riscos são mais facilmente estimados, selecionados e agrupados pelas seguradoras mediante o emprego de métodos empíricos e estatísticos ${ }^{106}$.

Já os riscos subjetivos são de aferição mais complexa, pois comportam elementos psicológicos do segurado. É fato que, além do aparato técnico e estatístico, a seguradora também se vale das declarações do segurado, nas quais irá se basear para subscrever o risco. É neste momento que a assimetria de informações entre segurado e seguradora pode colocar esta última em posição de desvantagem em relação ao segurado, pois, neste ponto, ela depende da boa-fé do segurado e dos dados que lhes são fornecidos.

\footnotetext{
${ }^{106}$ Ensina Nicola Gasperoni que a determinação do risco resulta da determinação seja da qualidade, da extensão e da intensidade da atividade do segurado, seja no que se refere ao tempo, ao espaço e à quantidade dos meios adotados para o exercício daquela atividade. Nas palavras do autor: "La determinazione del rischio risulta dalla determinazione sia della qualità, dell'estensione e della intensità dell'attività dell'assicurato, sia per quanto riguarda il tempo, lo spazio e la quantità dei mezzi adoperati per l'esercizio di quella attività." GASPERONI, Nicola, op. cit., p. 457.
} 
Neste cenário, discute-se se a relativa falta de ingerência da seguradora sobre os elementos psicológicos, aliada à ampla cobertura que o seguro de responsabilidade estimularia um comportamento de risco por parte do segurado ${ }^{107}$. O risco composto dos elementos subjetivos ora referidos é designado "risco moral" (moral hazard). Para O. D. Dickerson, o risco moral compreende "a propensão intangível de um indivíduo segurado à produção de perdas" ${ }^{108}$.

Em matéria securitária, Robin Pearson o define como "uma característica subjetiva intrínseca ao segurado que aumenta a probabilidade de uma perda." ${ }^{109}$ Omri Ben-Shahar et al. o conceituam como "a ideia de que uma parte segurada contra um risco tem um incentivo sub-ótimo para reduzi-lo." 110 e, nesta mesma linha, Steven Shavell o define como “a tendência da proteção securitária de alterar a motivação de um indivíduo para prevenir uma perda." 111 . J. M. Buchnan acrescenta que se trata de "todo desvio do adequado comportamento humano que pode representar um problema para a seguradora" ${ }^{\text {112. }}$.

Para administrar o risco moral, a seguradora deve se cercar de informações o mais aprofundadas possível, bem como adotar medidas para mitigar este comportamento de risco do segurado, conforme detalhadas no capítulo que tratará da aplicabilidade do seguro (capítulo 6).

\footnotetext{
${ }^{107}$ Em sua dissertação de mestrado, Luis Augusto Roux de Azevedo constata que "a assimetria de informações pode levar à indução do comportamento do segurado ao comportamento de risco (quando haja cobertura total) ou à solução do problema de moral hazard pelo segurador mediante a não disponibilidade de cobertura, o que levaria à inexistência do contrato de seguro." AZEVEDO, Luis Augusto Roux. A Comutatividade do Contrato de Seguro, Dissertação de mestrado pela Faculdade de Direito da universidade de São Paulo, 2010, p. 90.

108“"[Moral hazard comprehends] the intangible loss-producing propensities of the individual assured." DICKERSON, O. D. Health Insurance, rev. ed. Homewood, Ill. 1963, p. 463.

${ }_{109}$ "An imputed subjective characteristic of the insured that increases the probability of a loss." PEARSON, Robin. Moral Hazard and the assessment of insurance risk in eighteenth and early nineteenth centrury Britain. Disponivel em <http://www.jstor.org/discover $/ 10.2307 / 4127750$ ?uid=3737664\&uid=2\&uid=4\&sid=21101174909363 > . Acesso em 15.12.2012.

${ }^{110 ،}$ "The moral hazard problem — the idea that a party who is insured against risk has suboptimal incentive to reduce it." BEN-SHAHAR, Omri e LOGUE, Kyle D., Outsourcing Regulation: How Insurance Reduces Moral Hazard. Working paper no. 12-004, Faculdade de Direito da Universidade de Chicago, 2012.

111"Moral hazard refers here to the tendency of insurance protection to alter an individuals motive to prevent loss." SHAVELL, Steven. On moral hazard and insurance, in The Quarterly Journal of Economics, Harvard University, publicado por John Wiley and Sons, Inc., 1979, pp. 541-562.

${ }^{112 ، " M o r a l ~ h a z a r d ~ i s ~ e v e r y ~ d e v i a t i o n ~ f r o m ~ c o r r e c t ~ h u m a n ~ b e h a v i o r ~ t h a t ~ m a y ~ p o s e ~ a ~ p r o b l e m ~ f o r ~ a n ~ i n s u r e r . ~}$ BUCHANAN, J. M., The Inconsistencies of the National Health Service, Inst. of Econ. Affairs Occas. Paper 7, Londres, 1964.
} 


\subsection{APURAÇÃO DA RESPONSABILIDADE CIVIL E ADMINISTRATIVA}

\subsubsection{DEVERES DO ADMINISTRADOR}

Os deveres de diligência, cuidado e lealdade, introduzidos por influência do standard of care do direito norte-americano, figuraram como elementos essenciais na avaliação da conduta dos administradores, ganhando inclusive previsão expressa na legislação pátria ${ }^{113}$.

Como regra geral, os administradores não são considerados pessoalmente responsáveis pelas obrigações contraídas em nome da companhia em virtude de ato regular de sua gestão. $\mathrm{O}$ ato de gestão será considerado regular quando praticado em observância aos deveres de diligência e de cuidado do administrador, conforme consagrados na LSA.

Espera-se, pois, que o administrador cuide dos negócios sociais com o mesmo empenho e dedicação que empregaria em negócio próprio, não podendo ser responsabilizado por erro de julgamento quando feito dentro dos limites de seus poderes, com autorização dos sócios e de boa fé.

Para fins deste trabalho, o dever de diligência é de especial interesse por guardar estreita relação com a definição do padrão de conduta dos administradores. De acordo com Lamy Filho e Bulhões Pedreira, este é o dever de maior amplitude, sendo os demais, a rigor, "meros desdobramentos e exemplificações do padrão de comportamento dos administradores definido pela lei em vigor" ${ }^{114}$. Por este motivo, analisaremos o dever de diligência separadamente em relação aos demais deveres do administrador.

\footnotetext{
${ }^{113}$ De acordo com a LSA, são deveres e obrigações dos administradores: (i) dever de diligência, empregando o mesmo cuidado e diligência que todo homem ativo e probo emprega em seus próprios negócios; (ii) agir dentro da finalidade de suas atribuições e sem desvio do poder, não praticando atos de liberalidade, ou atos não autorizados, nem receber vantagem pessoal decorrente de seu cargo; (iii) mesmo que eleito por determinado grupo ou classe de acionistas, ter para com a companhia os mesmos deveres que os demais, não podendo, ainda que para a defesa dos interesses daqueles que os elegeram, faltar a esses deveres; (iv) dever de lealdade; (v) agir sem conflito de interesse, intervindo em qualquer operação que tenha interesse conflitante com o da companhia; e (vi) dever de informar.

${ }^{114}$ LAMY FILHO, Alfredo e PEDREIRA, José Luiz Bulhões, A Lei das S.A., Rio de Janeiro: Ed. Ronovar, 1992, p. 235. No mesmo sentido, pontua Luiz Antonio de Sampaio Campos: "A LSA determina no primeiro artigo da Seção Deveres e Responsabilidades dos Administradores o dever que é a pedra de toque da atuação dos administradores [...]. É, em uma palavra, a "chave" da responsabilização dos administradores.". CAMPOS, Luiz Antonio de Sampaio. Deveres e Responsabilidades. Direito das Companhias (org. Alfredo Lamy Filho e José Luiz Bulhões), v.1, Rio de Janeiro: Ed. Forense, 2009, p. 1097.
} 


\subsubsection{DEVER DE DILIGÊNCIA}

Previsto no artigo 153 da LSA $^{115}$, o dever de diligência dos administradores está consubstanciado na regra geral de que o administrador da companhia deve empregar, no desempenho de suas atribuições, o cuidado e diligência que todo homem ativo e probo costuma empregar na administração dos seus próprios negócios.

O dever de diligência, em sentido lato, comporta aspectos subjetivos que sinalizam a pretensão do sujeito de agir com cuidado, atenção e zelo em relação às obrigações a que está sujeito, e aspectos objetivos, que estabelecem um referencial pragmático, um standard comportamental dos administradores ${ }^{116}$.

A LSA limitou-se a instituir um padrão esperado de comportamento, não estabelecendo o conteúdo da conduta e dos atos que estariam em linha com o dever de diligência. Diferentemente da diligência esperada do bonus parter familias, a LSA exige do administrador a diligência própria de profissional ${ }^{117}$, haja vista que a diligência do "bom pai de família" tende a se manifestar de forma conservadora e, portanto, não trata o patrimônio sob a ótica empresarial ${ }^{118}$.

Apesar de não delinear claramente os contornos do dever de diligência, a LSA exige do administrador a diligência ordinária, típica da atividade profissional de gestão. A fim de determinar se a conduta poderia ser razoavelmente esperada, o intérprete deverá basear sua análise em fatores como (i) tipo de atividade exercida, bem como sua amplitude e relevância; (ii) recursos disponíveis para o exercício da gestão; (iii) momento e

\footnotetext{
${ }^{115}$ Art. 153 - O administrador da companhia deve empregar, no exercício de suas funções, o cuidado e diligência que todo homem ativo e probo costuma empregar na administração dos seus próprios negócios.

${ }^{116}$ Conforme PARENTE, Flavia, O Dever de Diligência dos Administradores das Sociedades Anônimas, Rio de Janeiro: Ed. Renovar, 2005, p. 38.

${ }^{117}$ O próprio artigo 152 da LSA evidencia o caráter profissional da administração: “Art. 152 - A assembleia geral fixará o montante global ou individual da remuneração dos administradores, inclusive benefícios de qualquer natureza e verbas de representação, tendo em conta suas responsabilidades, o tempo dedicado às suas funções, sua competência e reputação profissional e o valor dos seus serviços no mercado.

118، O comportamento do bom pai de família não se ajusta ao do administrador da companhia. O modelo teórico do bom pai de família, proveniente do direito romano, remete a uma pessoa conservadora e avessa a riscos, preocupada mais em preservar o patrimônio do que em aumentá-lo. A estrutura da companhia pressupõe a propensão ao risco empresarial e, muitas vezes, a adoção de posturas criativas e inovadoras." CAMPOS, Luiz Antonio de Sampaio, op. cit, p. 1.101.
} 
circunstâncias em que uma decisão foi tomada; e (iv) outras particularidades, incluindo atributos individuais dos administradores que motivaram sua nomeação ${ }^{119}$.

Conjuntamente avaliados, estes fatores permitiriam definir a conduta que seria razoavelmente esperada do administrador em situação semelhante para, com base nela, averiguar se, no caso concreto, foi empregado o grau de diligência que seria condizente com a situação em tela.

Estes elementos balizariam inclusive as expectativas de conduta nas situações práticas, uma vez que os atos de gestão de um administrador profissional, munido de meios de aconselhamento, acesso à informação e recursos disponíveis pressuporiam um nível mais elevado e rigoroso de diligência com relação a um administrador menos capacitado, desinformado e desprovido de recursos.

A diligência deve ser apreciada ainda (i) in abstracto, com referência ao caso concreto; (ii) à luz da realidade à época em que a decisão foi tomada (análise ex post facto); e (iii) com fundamento na conduta, não no mérito da decisão de gestão.

Em matéria de direito comparado, boa parte dos ordenamentos possui previsão dos deveres éticos e morais, bem como parâmetros de conduta em que devem se basear os administradores no exercício de suas atribuições. Nota-se que o fortalecimento do caráter institucional das companhias afastou o caráter de mandatário do administrador e motivou a introdução de deveres intimamente ligados às funções de cunho empresarial.

Na Alemanha, fala-se em diretor de empresa diligente e consciencioso, em linha com a importância das grandes companhias na economia. Na Itália, até a reforma de 2003, fazia-se referência à diligência própria de mandatário. Atualmente, o código civil italiano alude à diligência requerida pela natureza da atividade empresarial e da função e específica competência do administrador. Em Portugal, atribui-se ao diretor o dever de diligência de gestor criterioso e ordenado ${ }^{120}$.

\footnotetext{
${ }^{119}$ Conforme ADAMEK, Marcelo Vieira von. Responsabilidade civil dos administradores de S/A e as ações correlatas, São Paulo: Saraiva, 2009, p. 125.

${ }^{120} \mathrm{O}$ Decreto-Lei 76-A/2006 de 29 de março pormenorizou a conduta, incluindo nominalmente os deveres de cuidado e de lealdade. Confira-se: "Art. 64 - Deveres Fundamentais. 1. Os gerentes ou administradores da sociedade devem observar: (a) deveres de cuidado, revelando a disponibilidade, a competência técnica e o
} 
Na Inglaterra, o diretor deve, na execução de suas tarefas, demonstrar ao menos o grau de diligência esperado de um indivíduo com o seu conhecimento e experiência. Analogamente, nos Estados Unidos da América, aplica-se a business judgement rule, avaliando-se a razoabilidade do processo decisório frente ao grau de cuidado e diligência que um diretor ordinariamente prudente deveria razoavelmente exercer numa posição semelhante sob circunstâncias similares.

A business judgement rule ${ }^{121}$ é uma regra norte-americana de origem jurisprudencial que estabelece uma presunção genérica de que os atos de administração são regulares, se realizados com conhecimento e informação adequados, de boa fé e no melhor interesse da companhia. Por esta razão, restringe-se o escopo da análise dos tribunais à apreciação da conduta de gestão, devendo a avaliação que faz o Judiciário ater-se à razoabilidade e grau de informação do processo decisório (reasonable decision making process) (via de regra, não se analisa o mérito da decisão).

Assim como no direito estrangeiro, em matéria de direito pátrio, a manifestação da observância do dever de diligência no plano concreto desdobra-se em uma série de deveres correlatos a serem seguidos pelo administrador diligente, tais como o dever de participar, o dever de coletar informações, o dever de vigiar, fiscalizar, supervisionar, o dever de investigar, o dever de intervir.

É válido esclarecer que o regular cumprimento do dever de diligência não está associado à realização imponderada de toda e qualquer medida tomada em assembleia (a

conhecimento da atividade adequados às suas funções e empregando nesse âmbito a diligência de um gestor criterioso e ordenado; e (b) deveres de lealdade [...]." Disponível em $<$ www.umic.pt/images/stories/publicacoes/DL\%2076A\%202006.pdf>. Acesso em 15.10.2012.

121 "Para evitar os efeitos prejudiciais da revisão judicial, o Poder Judiciário americano criou a chamada 'regra da decisão negocial' (business judgement rule), segundo a qual, desde que alguns cuidados sejam observados, o Poder Judiciário não irá rever o mérito da decisão negocial em razão do dever de diligência. A proteção especial garantida pela regra da decisão negocial também tem por intenção encorajar os administradores a servir à companhia, garantindo-lhes um tratamento justo, que limita a possibilidade de revisão judicial e decisões negociais privadas (e que possa impor responsabilidade aos administradores), uma vez que a possibilidade de revisão ex post pelo Poder Judiciário aumenta significativamente o risco a que o administrador fica exposto, podendo fazer com que ele deixe de tomar decisões mais arriscadas, inovadoras e criativas (que podem trazer muitos benefícios à companhia), apenas para evitar o risco de revisão judicial posterior. Em razão da regra da decisão negocial, o Poder judiciário americano preocupa-se apenas com o processo que levou à decisão e não com o seu mérito." (CVM, Proc. nº RJ-1443/2005, Rel. Dir. Pedro Oliva Marcilio de Souza, v.u., j. 21-3-2006). 
abstenção fundamentada do administrador com relação a determinada deliberação não pode ser confundida com a quebra do dever de diligência).

Como a administração não é mandatária da assembleia geral (a relação entre elas é majoritariamente de controle e orientação, não de total subordinação), os administradores não estão obrigados a cumprir todas as deliberações da assembleia geral; pelo contrário, ele podem deixar de dar cumprimento a decisões assembleares quando julgarem que afrontam ou usurpam competências privativas da administração ou que infringem a lei ou estatuto) $^{122}$.

\subsubsection{OUTROS DEVERES}

A LSA estabelece que são deveres gerais do administrador ${ }^{123}$ : (ii) o dever de diligência; (ii) dever de dar cumprimento às finalidades das atribuições do cargo; (iii) dever de lealdade; (iv) deveres próprios sobre conflito de interesses; (v) dever de sigilo; (vi) dever geral de vigilância.

De acordo com Marcelo Vieira von Adamek, afora estes deveres amplos e gerais, aos administradores ainda incumbem deveres específicos arrolados de forma esparsa na LSA (e.g., dever de manter a escrituração dos livros sociais e o dever de participar da assembleia geral $^{124}$ ) e deveres implícitos, como cumprir a lei e as disposições do estatuto ${ }^{125}$.

Seja o dever de diligência, sejam os outros deveres que incumbem ao administrador, importa notar que a observância destes parâmetros de comportamento é decisiva para a apuração da responsabilidade pessoal do administrador. Estando as condutas que ensejam responsabilização penal excluídas do âmbito de cobertura da apólice, para fins deste trabalho, a apuração da responsabilidade dos administradores será centrada nas esferas civil e administrativa.

\footnotetext{
122،Não são impositivas, por evidente, as deliberações usurpadoras de competência privativa de órgão da administração e aquelas violadoras da lei e dos estatutos, que, em sendo cumpridas, possam redundar na responsabilidade pessoal do administrador.”. FRANÇA, Erasmo Valladão Azevedo e Novaes, Invalidade das deliberações de assembleia das S.A., São Paulo: Malheiros, 1999.

${ }^{123}$ Artigos 153 a 157 da LSA.

${ }^{124}$ Conforme artigos 104 e 134 , parágrafo $1^{\circ}$ da LSA, respectivamente.

${ }^{125}$ ADAMEK, Marcelo Vieira von, op. cit, p. 120.
} 


\subsubsection{APURAÇÃO DA RESPONSABILIDADE CIVIL}

Sem prejuízo da análise dos deveres e dos demais parâmetros previstos pela lei acionária que devem nortear a conduta dos administradores, conforme abordados no início deste capítulo, centraremos a discussão sobre o artigo que trata nominalmente do dolo e da culpa, in verbis:

Art. 158. O administrador não é pessoalmente responsável pelas obrigações que contrair em nome da sociedade e em virtude de ato regular de gestão; responde, porém, civilmente, pelos prejuízos que causar, quando proceder:

I - dentro de suas atribuições ou poderes, com culpa ou dolo;

II - com violação da lei ou do estatuto.

A leitura deste artigo permite a apreensão dos três pressupostos básicos fundamentais da responsabilidade dos administradores: (a) a conduta antijurídica do agente; (b) o dano causado à companhia, acionistas ou outro terceiro de boa-fé; e (c) o nexo de causalidade (liame de causa e efeito) entre a conduta do agente e o dano experimentado pelo lesado ${ }^{126}$.

No que concerne ao comportamento antijurídico, a LSA estabelece a irresponsabilidade pessoal do administrador por atos regulares de gestão. Esta previsão decorre do fato de ser a administração órgão da companhia e o administrador, ao exteriorizar a vontade social, faz com que a própria companhia exerça direitos e assuma obrigações perante terceiros.

Ora, não podem os terceiros desejar responsabilizar pessoalmente o administrador por atos e operações realizados no curso regular de sua gestão, ainda que, ao cabo da situação, prejuízos sejam gerados.

A contrario sensu, atos irregulares de gestão importam responsabilização pessoal do administrador e, como parâmetros para aferição da regularidade do ato, a LSA determina que este deve ser previsto na lei ou no estatuto e não pode extrapolar as

${ }^{126}$ Conforme ADAMEK, Marcelo Vieira von, op. cit., p. 210. 
atribuições atinentes ao cargo que ocupa, condição sem a qual seria caracterizada, de forma semelhante, ato contrário à lei e ao estatuto.

Como bem observa José Alexandre Tavares Guerreiro, parece de fato haver coincidência de objeto nos incisos I e II do artigo 158 da LSA, tendo o legislador pátrio "incidido em manifesta tautologia, ao erigir como pressuposto da irresponsabilidade do administrador a condicionante de ter o ato por ele praticado se revestido da conotação necessária de ato regular de gestão", haja vista que, se "os únicos parâmetros admissíveis para a aferição da regularidade do ato de gestão são exatamente os preceitos da lei e as disposições do estatuto", conclui o referido autor que "não há sentido para a duplicidade de condições" $" 127$.

A distinção feita pela lei, contudo, prova não ter sido vã quando examinada sob a ótica da natureza da conduta do administrador: lícita ou ilícita, culposa ou não culposa.

De acordo com os ensinamentos de Marcelo Vieira von Adamek:

A culpa lato sensu (culpa ou dolo), referida na lei acionária, corresponde à culpa civil (CC, art. 186). Mas, para bem caracterizá-la, é necessário recorrer ao standard específico do dever de diligência (LSA, art. 153). Reitere-se o quanto antes já expendido, no sentido de que a diligência exigida do administrador é a normal ou ordinária, e não de maior ou menor intensidade, mas que deve ser aferida em confronto com o tipo de atividade exercida pela companhia, inclusive a sua dimensão e importância, os recursos disponíveis e a sua qualidade de administrador de bens alheios. Em suma, para saber se o comportamento do agente foi ilícito ou não, a avaliação é feita em abstrato (juízo de ilicitude). Daí a poder dizê-lo culpável, a aferição é feita segundo as particularidades do caso, não mais in abstracto, mas in concreto (juízo de culpabilidade) ${ }^{128}$.

A fim de determinar se seria repreensível a conduta do administrador que agiu no exercício de suas atribuições, é preciso dissociar as apreciações de licitude e de culpa, conforme as lições de Luís Brito Correia:

Quando se aprecia a "culpa" de certo agente, em abstrato, o que se faz é verificar, perante certo ato, se o agente se comportou ou não de acordo

\footnotetext{
${ }^{127}$ Conforme GUERREIRO, José Alexandre Tavares, Responsabilidade dos Administradores de Sociedades Anônimas, in Revista de Direito Mercantil, Industrial, Econômico e Financeiro, ano XX (nova série), $n^{\circ} 42$, São Paulo: RT, abril/junho 1981, p. 73.

${ }^{128}$ Conforme ADAMEK, Marcelo Vieira von, op. cit., pp. 213-214.
} 
com certa norma que se toma como modelo (a norma seguida pelo bom pai de família, por exemplo). Ora, este é o tipo de raciocínio característico do juízo de ilicitude, não do juízo de culpabilidade: é ilícito $\mathrm{o}$ ato concreto que não corresponde ao ato devido; em contrapartida, dizse culpado o agente, quando é censurável por ter praticado um ato ilícito, quando podia ter atuado de outro modo (concordante com o direito). Ao determinar a culpabilidade, o que se vai saber é se o agente podia ter atuado conforme o direito, e este juízo só pode ser concreto, não abstrato $^{129}$.

Destarte, o cotejo e a comprovação da culpa do administrador que faltou com seu dever de diligência incumbem ao autor de eventual ação de indenização que, no curso da ação, deverá provar (i) a conduta (comissiva ou omissiva) do administrador; (ii) a conduta que teria sido mais correta e, portanto, dele esperada sob o prisma do dever de diligência; e (iii) a inadequação daquela conduta concreta à luz da conduta abstrata ${ }^{130}$.

Por outro lado, na hipótese de transgressão à lei ou estatuto, grande parte dos autores defende que a culpa seria presumida ${ }^{131}$, operando-se a inversão do ônus da prova. Isto se justificaria pelo fato de a violação não-culposa de lei ou do estatuto seria identificada apenas em situações excepcionalíssimas em que o administrador não dispunha de alternativa que beneficiasse a companhia que fosse diferente daquela pela qual optou.

Concluído o juízo acerca da antijuridicidade do comportamento do administrador, para precisar a sua responsabilidade pessoal, resta apreciar os outros dois pressupostos aludidos no início deste capítulo: o nexo de causalidade e a existência do dano.

Para comprovação do liame de causalidade entre o dano e o comportamento jurídico do comportamento antijurídico do agente (nexo de causalidade), é preciso apontar a relação de causa e efeito entre a conduta do administrador e a ocorrência do dano. A prova deste requisito é extremamente dificultosa, notadamente porque, no contexto societário, as operações empresariais estão vinculadas à atuação de diversos indivíduos e à série de fatos e eventos sucessivos que se perdem no tempo.

\footnotetext{
${ }^{129}$ CORREIA, Luis Brito, Os administradores de sociedades anônimas, Coimbra: Livraria Almedina, 1993, p. 596.

${ }^{130}$ Conforme ADAMEK, Marcelo Vieira von, op.cit., p. 215.

${ }^{131}$ Conforme GUERREIRO, José Alexandre Tavares, op. cit, p. 80. Cf. ADAMEK, Marcelo Vieira von, op. cit., p. 216. Cf. BULGARELLI, Waldírio. Comentários à lei das sociedades anônimas, v.4, São Paulo: Saraiva, 1978, p. 97.
} 
Por estas características, podem ter contribuído para o dano diversos agentes, assim como pode ter o dano sido desencadeado por uma série de fatores anteriores à própria conduta do administrador, comprometendo a determinação exata do agente causador do dano e da causa efetiva de tal dano.

Igualmente complexa é a tarefa de provar o último requisito para que sejam civilmente responsabilizados os administradores: a existência do dano. A potencialidade lesiva do ato, por si só, não é suficiente para que se alegue dano. É necessário que o autor mostre que o fato de que se queixa, na ação, seja de natureza prejudicial, danosa ${ }^{132}$.

Sobre as dificuldades nesta seara, Marcelo Vieira von Adamek tece os seguintes comentários:

O dano também não pode ser estimado simplesmente a partir do resultado geral do exercício social. Seja porque a companhia pode ter tido lucro no exercício, mas prejuízo em certa operação, como consequiência do ato ilícito praticado pelo administrador, e isso não será detectado por meio da análise do resultado geral da companhia, quer no balanço (LSA, arts. 176, I, e 178), quer na demonstração de resultados do exercício (LSA, arts. 176 , III, e 187) ou em outra demonstração financeira qualquer. ${ }^{133}$.

A minuciosa apuração da culpa evidencia a exata medida dos percalços comprobatórios aos pressupostos da responsabilidade civil dos administradores que, aliados à complexa realidade societária em que se inserem e ao baixo número de ações de responsabilidades (vide seção 5.4.4), tenderiam a criar um ambiente propício para que administradores se valessem da cobertura securitária para atuar de forma menos diligente, expondo a seguradora ao risco moral.

É justamente para averiguar os impactos do risco moral neste cenário que, mais adiante, o seguro será examinado à luz de sua aplicabilidade no âmbito da administração das companhias.

\footnotetext{
${ }^{132}$ Conforme DIAS, José Aguiar, Da responsabilidade Civil, v. II, Rio de janeiro: Forense, 1997, p. 101.

${ }^{133}$ Conforme ADAMEK, Marcelo Vieira von, op. cit., p. 232.
} 


\subsubsection{APURAÇÃO DA RESPONSABILIDADE ADMINISTRATIVA}

Como visto, a CVM é o órgão habilitado para apurar a responsabilidade dos administradores no âmbito administrativo. Para tanto, o exercício do poder sancionador destinado à responsabilização e eventual penalização dos infratores está condicionado à observância de procedimentos específicos ${ }^{134}$.

\subsubsection{O PROCEDIMENTO ADMINISTRATIVO}

A atividade punitiva da CVM, orientada pelo princípio do devido processo legal, segue uma série de procedimentos instaurados no âmbito dos chamados processos administrativos sancionadores ${ }^{135}$.

Uma crescente tendência de jurisdicionalização do processo disciplinar tem marcado os procedimentos administrativos modernos. A presença de elementos como (i) a definição legal das faltas e penas; (ii) o estabelecimento do princípio da ampla defesa; (iii) a implementação de normas que facultem o contraditório; e (iv) a concessão de recursos) são prova desta tendência ${ }^{136}$.

Estes elementos são imprescindíveis aos processos administrativos, pois asseguram maior objetividade aos procedimentos destinados à apuração de faltas disciplinares, ao mesmo tempo em que ajudam a conter o poder discricionário das autoridades administrativas.

Especialmente no que diz respeito à definição legal das faltas e punições, a Lei 6.385/76 prevê uma série de standards legais, tais como "práticas não equitativas" e "fraude ou manipulação destinadas a criar condições artificiais de demanda, oferta ou preço de valores mobiliários"137.

\footnotetext{
${ }^{134}$ Conforme CARVALHOSA, Modesto. Responsabilidade civil de administradores e de acionistas controladores perante a Lei das S/A, in Revista dos Tribunais, v. 699, nº 83, jan. 1994, p. 39.

${ }^{135}$ Os procedimentos relativos à instauração de inquérito administrativo e de processo administrativo pela CVM são regidos pelas Resoluções do Conselho Monetário Nacional nºs 454/77 e 1.657/89.

${ }^{136}$ Conforme EIZIRIK, Nelson, op. cit., p. 57.

${ }^{137}$ Artigos $9^{\circ}$, V e $4^{\circ}$, IV(b) da Lei 6.385/76, respectivamente.
} 
Se de um lado se admite a responsabilidade administrativa pelo descumprimento de um standard legal, de outro, seria inaceitável a imposição de penalidades administrativas sem que houvesse uma definição precisa da responsabilidade do indiciado e do standard legal.

A aplicação de penalidades pela CVM deve pressupor a culpa própria, concreta e individual de cada indiciado, devendo ser exaustivamente examinada sua participação no ato considerado ilegal ${ }^{138}$. Assim, previamente à imposição da penalidade, o colegiado da CVM deve estar munido de todos os elementos que o convenceram da culpa do indiciado, tais como evidências concretas colhidas durante o inquérito administrativo ou a demonstração de violação da lei sem a prova de ausência de culpa do acusado indiciado.

Segundo Nelson Eizirik, no curso de alguns processos administrativos, tem-se argumentado que a responsabilização dos indiciados prescinde em absoluto da verificação dos prejuízos decorrentes de sua atuação. Em outras palavras, sugere-se que a aplicação das penalidades independe da ocorrência de danos reais, sendo suficiente a caracterização do ato ilícito para a imposição das penalidades cabíveis.

Como exposto anteriormente, é fato que, diversamente do que ocorre na esfera da responsabilidade civil, os prejuízos causados no âmbito administrativo atingem não só investidores determinados, mas o mercado como um todo. Não obstante, este autor pondera que "mesmo assim, não se pode, evidentemente, pressupor que qualquer infração à lei causa 'prejuízo ao mercado', sob pena de se resvalar em autêntica idolatria das normas jurídicas" 139 .

Destarte, o procedimento sancionador que tutela adequadamente os interesses dos administradores e do mercado parece ser aquele em que, guardadas as distinções entre os processos administrativos e judiciais, assegure as garantias processuais ao administrador e

\footnotetext{
${ }^{138}$ Conforme EIZIRIK, Nelson, op. cit., p. 59. Neste mesmo sentido, confiram-se as palavras de Modesto Carvalhosa: "Deve ser salientado que no processo administrativo é necessária a plena caracterização da responsabilidade de cada um dos indiciados, ainda que pertençam a órgão colegiado e evidenciada a sua culpa concreta. No âmbito administrativo, não há responsabilidade objetiva. A demonstração da ilicitude do ato, e a prova do elemento intencional que baseia a culpa, são pressupostos da aplicação de qualquer sanção de natureza administrativa." CARVALHOSA, Modesto, op. cit., p. 39.

${ }^{139}$ Conforme EIZIRIK, Nelson, op. cit., p. 61.
} 
resulte na imposição de penalidade quando esteja caracterizada a culpa concreta do administrador e o prejuízo que sua conduta acarretou.

\subsubsection{AS PENALIDADES IMPOSTAS PELA CVM}

O exame do caráter das penalidades impostas pela CVM é de especial importância para a discussão que se colocará acerca das possíveis coberturas oferecidas pelo seguro de responsabilidade civil de administradores.

Enquanto o sistema de responsabilidade civil volta-se à garantia da reparação do dano à vítima, a responsabilização administrativa parece ter uma função mais abrangente, i.e., dirige-se não só ao indivíduo lesado a ser ressarcido, mas à coletividade, ao mercado de valores mobiliários como um todo.

No exercício do poder sancionador, a CVM está autorizada a aplicar as seguintes penalidades: (i) advertência; (ii) multa; (iii) suspensão do exercício de cargo; (iv) inabilitação temporária, até o máximo de vinte anos; (v) suspensão de autorização ou registro para o exercício de atividades; (vi) cassação de autorização ou registro para o exercício de atividades; (vii) proibição temporária, até o máximo de vinte anos, para a prática de determinadas atividades ou operações; e (viii) proibição temporária, até o máximo de dez anos, para a atuação em modalidades de operação no mercado de valores mobiliários $^{140}$.

À exceção da multa e da advertência, as penalidades somente poderão ser impostas no caso de infração grave, assim entendidas aquelas enumeradas na Instrução CVM no 491 de 21 de fevereiro de 2011. Nos termos do referido normativo, são exemplos de infração grave relacionada aos deveres dos administradores o descumprimento dos deveres fiduciários de diligência e lealdade, o desvio de poder e o conflito de interesses ${ }^{141}$.

Como se nota, em oposição às sanções impostas no âmbito judicial quando da responsabilização civil - que visam tutelar os interesses da vítima e lhe assegurar a reparação do dano, as sanções administrativas aplicadas pela CVM visam garantir as

\footnotetext{
${ }^{140}$ Art. 11 da lei 6.385/76.

${ }^{141}$ Arts. 153 a 156 e 165 da Instrução CVM no 491/11.
} 
condições necessárias ao desenvolvimento e ao adequado funcionamento do mercado de capitais.

As sanções administrativas destinam-se, pois, a evitar que o infrator reincida na prática do ilícito e que outros indivíduos cometam as mesmas faltas ou pratiquem atos que afrontem a legislação e a regulamentação aplicáveis ao mercado de capitais. Sem prejuízo da atribuição da CVM de proteger o pequeno investidor, as penalidades por ela impostas não visam ao ressarcimento de eventuais prejuízos causados aos investidores. A multa é, portanto, uma sanção pecuniária sem caráter de composição de prejuízos a terceiros ${ }^{142}$.

\subsubsection{TERMO DE COMPROMISSO}

Observados os requisitos previstos na Lei 6.385/76 (artigo 11, parágrafo $5^{\circ}$ ), a CVM pode, a seu critério, suspender o procedimento administrativo contanto que o investigado ou infrator aceite firmar termo de compromisso pelo qual se compromete a cessar a prática das atividades ou atos considerados ilícitos pela CVM, bem como a corrigir as irregularidades apontadas, inclusive indenizando os prejuízos.

Conquanto a indenização de prejuízos não seja condição sine qua non para a celebração do termo de compromisso - pois ela pressupõe a existência de um prejuízo quantificável e a possibilidade de identificação dos prejudicados ${ }^{143}$ - frequentemente as propostas de termo de compromisso aceitas pela CVM preveem indenização aos prejudicados (a contrario sensu, as propostas de termo em que o compromitente não sugere um valor a ser pago a título de indenização são comumente rejeitadas pela CVM) $)^{144}$.

\footnotetext{
${ }^{142}$ Conforme EIZIRIK, Nelson et al. Mercado de Capitais - Regime Jurídico. Rio de Janeiro: Renovar, 2008, p. 319 .

${ }^{143}$ Conforme EIZIRIK, Nelson et al., op. cit, p. 337.

${ }^{144}$ Apreciação de Proposta de Termo de Compromisso - PAS 24/2006 - Telemig Celular S.A. e Amazônia Celular S.A. Reg. $\mathrm{n}^{\circ}$ 6944/09: "O Comitê de Termo de Compromisso entendeu que a proposta não cumpre integralmente os requisitos legais necessários à celebração de Termo de Compromisso, uma vez que não contempla obrigação de indenização do prejuízo sofrido pela Telemig Celular S.A. [...] O Colegiado, acompanhando o entendimento exposto no parecer do Comitê, deliberou a rejeição da proposta de Termo de Compromisso apresentada pelo Sr. Ricardo Augusto de Oliveira Sacramento.”. Neste mesmo sentido: Apreciação de Proposta de Termo de Compromisso - PROC. RJ2011/2522 - Fundação Rede Ferroviária de Seguridade Social - REFERReg. $n^{\circ} 7639 / 11$.
} 
A propósito, ainda que não seja possível individualizar cada um dos terceiros prejudicados (situação em que o valor avençado no termo destinado é integralmente à CVM), não se poderia dizer que o montante devido perderia o caráter indenizatório. Em última instância, o valor pago a tal autarquia teria por finalidade a reparação do dano à coletividade de investidores, ao mercado de capitais como um todo.

Confira-se nos dizeres da Procuradoria Federal Especializada perante a CVM (PFE/CVM) e da doutrina:

Nada obstante o acima afirmado acerca da existência de danos a investidores que negociaram com os valores mobiliários sem o conhecimento da informação relevante, bem como aqueles que deixaram de negociar justamente por não deter tal informação, entendemos que não seria possível no mesmo âmbito de um processo administrativo sancionador, e, mais especificadamente, no bojo de um termo de compromisso, uma segura e objetiva individualização de prejudicados e seus respectivos ressarcimentos.

Assim sendo, temos que nesses casos, a única forma de efetiva recomposição de prejuízos, nos termos do art. $11, \S 5^{\circ}$, II, da Lei 6.385/76, é a reparação ao dano difuso causado à higidez, estabilidade e eficiência do mercado, cuja tutela incube a esta autarquia, conforme disposto no art. $4^{\circ}$ da Lei $n^{\circ} 6.385 / 76$, sob pena de se inviabilizar a celebração de Termos de Compromisso em casos semelhantes ao ora analisado.

Parece-nos, outrossim, que, ainda que haja dificuldade em se especificar prejudicados, há efetivamente, um claro prejuízo passível de mensuração, cujo valor deve equivaler, s.m.j. e no mínimo, à vantagem econômica obtida com a negociação, com as devidas atualizações monetárias.

Portanto, para que a proposta atenda aos requisitos legais, faz-se necessário que a mesma contemple um cálculo dos ganhos auferidos com as operações supostamente ilícitas, parecendo-nos que, sob prisma estritamente jurídico, tal montante é a base mínima para qualquer proposta de termo de compromisso. (Memorando da Procuradoria Federal Especializada perante a CVM - PFE/CVM - MEMO/PFE-CVM/GJU1/No285/09, nos autos do Processo Administrativo Sancionador CVM n ${ }^{\circ}$ 19/2006)

Cumpre diferenciar duas situações fático-jurídicas que, comumente, são submetidas à apreciação do Colegiado da Autarquia reguladora do mercado de capitais. A primeira, e mais simples, ocorre quando é possível extrair dos autos ou da própria peça acusatória a quantificação do prejuízo sofrido diretamente por um ou mais investidores. Neste caso, a possibilidade jurídica de aceitação da proposta pela CVM está condicionada à apresentação de compromissos que contemple a respectiva indenização aos investidores potencialmente lesados.

No entanto, é bastante comum que o ilícito perpetrado pelo proponente seja daqueles que, apesar de não gerarem danos a investidores individualizados, acarretem, em tese, danos aos 
interesses difusos ou coletivos no âmbito do mercado de capitais, notadamente potencial lesão à integridade, à transparência e à confiabilidade, que são valores essenciais no mercado de que se cuida. Assim, e considerando que a Lei exige a indenização de todos os prejuízos causados pela suposta prática ilícita, a PFE-CVM tem opinado sistematicamente pela juridicidade de propostas de recomposição de danos por meio de medida(s) diretamente direcionadas ao mercado mobiliário como um todo, ou mesmo indiretamente, na pessoa do seu órgão regulador (CVM), que tem como um dos seus objetivos legais a promoção da expansão e do funcionamento eficiente do mercado de capitais (art. $4^{\circ}$ da Lei $\left.n^{\circ} 6.385 / 76\right)$.

Nesta linha, considerando a impossibilidade material de quantificação de prejuízos em situações acima referidas, cumpre ao Colegiado da CVM, em caráter discricionário, e após ouvido o adiante enfocado Comitê de Termo de Compromisso, examinar se a proposta apresentada se revela razoável e finalisticamente proporcional aos danos potencialmente causados $^{145}$.

Logo, à luz do disposto na lei, do entendimento da Procuradoria Federal Especializada perante a CVM e da doutrina, verifica-se que a natureza jurídica da obrigação pecuniária no âmbito do Termo de Compromisso, é a de indenização (ressarcimento de prejuízos), e não de multa.

Esta distinção é relevante na medida em que a natureza do termo de compromisso tem suscitado discussões acerca da aplicabilidade do seguro, especialmente no que tange à possibilidade de indenização securitária para cobrir o valor devido pelos administradores que for estipulado no termo de compromisso (vide seção 6.2.2.1).

\subsubsection{COBERTURA SECURITÁRIA E APURAÇÃO DA RESPONSABILIDADE}

Como visto, a apuração da responsabilidade do administrador na esfera civil, bem como a possibilidade de responsabilização penal, envolvem um processo criterioso sobre o qual incidem diversas variáveis de caráter extremamente subjetivo. A longa duração destes processos, associada aos obstáculos ora examinados para a comprovação da culpa ou o dolo do administrador, poderiam agravar o chamado risco moral (moral hazard) que, neste cenário, poderia ser entendido como um desestímulo para que o administrador aja de acordo com seus deveres.

\footnotetext{
${ }^{145}$ WELLISCH, Julya S. M; SANTOS, Alexandre P. O termo de compromisso no âmbito do mercado de valores mobiliários, in Revista de Interesse Público, Belo Horizonte, v.10, nº 53, 2008, pp. 137-150.
} 
Alie-se a isto o fato de as ações civis de responsabilidade de administradores serem pouco numerosas, sobretudo se comparadas aos processos na esfera administrativa ${ }^{146}$.

Um recente estudo identificou as prováveis causas do número quase inexpressivo de ações desta natureza, a saber:

Conforme visto, a sistemática legal dá ensejo a diversos obstáculos e desincentivos, principalmente financeiros, à propositura da ação:

(i) Dificuldade de caracterizar e provar que o administrador agiu com culpa ou dolo;

(ii) Provável desinteresse dos acionistas majoritários na propositura de ação social ut universi;

(iii) Altos custos/riscos e baixos benefícios associados às ações sociais ut singuli (principalmente quando a ação é julgada improcedente);

(iv) Impossibilidade de recomposição direta de danos indiretos por meio das ações sociais ut singuli;

(v) Em casos de companhias abertas com capital pulverizado, dificuldade de reunião de acionistas com participação acionária de no mínimo 5\% do capital social para mover ação social ut singuli derivada;

(vi) Dano reputacional à companhia ${ }^{147}$.

Vale analisar também outros dois entraves comuns às ações de responsabilidade do administrador, sejam ações sociais ou individuais, constatados no estudo:

O primeiro deles é a dificuldade de acesso a informações. Para a propositura e o sucesso da ação é importante que os reclamantes estejam munidos de informações capazes de respaldarem suas alegações. Essa dificuldade, obviamente, tende a ser menos problemática em casos de ações sociais ut universi, já que nessas ocasiões a propositura da ação está alinhada à vontade da maioria do capital social. A dificuldade de acesso a informações é mais comum aos acionistas minoritários, já que estes têm de enfrentar a resistência da maioria e a dificuldade de articulação.

Em segundo lugar, a propositura dessas ações é desestimulada quando não há certeza de que o administrador possui patrimônio suficiente para arcar com o ressarcimento dos prejuízos causados ${ }^{148}$.

\footnotetext{
146، De acordo com os dados reunidos ao longo deste trabalho, foi possível verificar que as ações de responsabilidade civil contra administradores de companhias abertas são escassas, especialmente se comparadas com o volume de processos administrativos sancionadores julgados pela CVM: não mais de 11 casos em esfera judicial contra 210 casos em esfera administrativa." (Avaliação realizada no período de período de 1/10/2000 a 31/12/2010). RODRIGUES, Ana Carolina. A responsabilidade civil dos administradores de companhias abertas não financeiras por danos causados à sociedade e aos acionistas e o desenvolvimento do mercado de valores mobiliários brasileiro. Tese de Mestrado em Direito pela Fundação Getúlio Vargas - Escola de Direito, 2011, p. 105.

${ }^{147}$ RODRIGUES, Ana Carolina, op. cit., p. 69.

${ }^{148}$ RODRIGUES, Ana Carolina, op. cit., p. 70.
} 
Com base nestes dados, é possível inferir que as dificuldades para comprovação de culpa ou dolo do administrador, aliadas ao contexto de ações de responsabilidade civil de administradores no Brasil, criam um ambiente relativamente favorável à proliferação de administradores que, resguardados pelo seguro de responsabilidade, atuem de forma menos diligente, negligenciem seus deveres ou assumam riscos desmedidamente.

Por oposição, diversos outros argumentos permitem refutar tais suposições. $\mathrm{Na}$ seara administrativa, por exemplo, a apuração da responsabilidade tende a ser mais simples e célere, enfraquecendo o argumento de que os administradores munidos do seguro são mais destemidos por possuírem um estímulo para um comportamento sub-ótimo.

Ademais, não obstante o suposto mau-incentivo e o risco moral que este seguro sugere, a nosso ver, as diversas hipóteses de afastamento da aplicabilidade do seguro decorrentes de elementos que não a simples apuração de responsabilidade pessoal do administrador indicam que o seguro não necessariamente incrementa o risco moral. Isto porque os desdobramentos da responsabilização do administrador não se restringem ao impacto patrimonial, o único desdobramento efetivamente amparado pelo seguro.

\subsection{RELAÇÃO ENTRE A RESPONSABILIDADE PESSOAL E A COBERTURA DAS APÓLICES DE SEGURO DE RESPONSABILIDADE CIVIL}

A cobertura do seguro de responsabilidade civil de administradores não se aplica se houver dolo ou culpa grave do segurado, conforme prevê o CC/02 ${ }^{149}$ e a Circular da SUSEP no 256 de 16 de junho de 2004, que disciplina a estruturação mínima das condições contratuais e das notas técnicas atuariais dos contratos de seguros de danos, in verbis:

Art. 22. Na relação dos riscos excluídos deverão constar os danos causados por atos ilícitos dolosos ou por culpa grave equiparável ao dolo praticados pelo segurado, pelo beneficiário ou pelo representante legal, de um ou de outro. (grifou-se)

Em matéria de responsabilidade civil, o dolo e a culpa do agente estão primordialmente ligados à conduta no âmbito do exercício da atividade gestacional, motivo

\footnotetext{
${ }^{149}$ Art. 762 - Nulo será o contrato para garantia de risco proveniente de ato doloso do segurado, do beneficiário, ou de representante de um ou de outro.
} 
pelo qual se discute se a existência do seguro levaria os administradores a ter condutas distintas quando amparados por seguro.

Em matéria securitária, o dolo pode estar relacionado não só ao juízo de culpabilidade do ato ou fato que sejam produto da conduta do segurado, mas também às declarações de vontade no momento da contratação do seguro, quando as afirmações feitas pelo administrador, bem como eventuais omissões e informações prestadas ocultarem a intenção de fraudar ou estiverem eivadas de má-féc ${ }^{150}$.

Sendo assim, em se tratando de seguro de responsabilidade de administradores, o dolo do administrador pode se manifestar em duas searas distintas: (i) o dolo atinente ao ato de gestão propriamente dito e que será examinado à luz das regras de responsabilização pessoal (análise sob a perspectiva da responsabilidade civil e administrativa, visto que a penal faz precluir o direito à cobertura); e (ii) o dolo atinente ao seguro, relacionado à existência ou não do animus de fraudar o seguro, seja no momento da contratação, seja quando da materialização do sinistro (análise sob a perspectiva securitária).

\subsubsection{ATO DO ADMINISTRADOR SOB A PERSPECTIVA DA RESPONSABILIDADE CIVIL E ADMINISTRATIVA}

No seguro de responsabilidade, em razão das dificuldades enfrentadas pelas seguradoras para justificar eventuais negativas de cobertura fundadas na prática de ato de gestão doloso ou com culpa grave, são raras as situações em que a negativa de cobertura ocorre desde logo, no momento da comunicação do sinistro.

A este respeito, é bom lembrar que, a verificação do cabimento ou não de indenização securitária em virtude da lesão ao bem segurado, embora também esteja presa à subjetividade da conduta do agente, é mais simples no que se refere ao seguro de danos a bens tangíveis, pois não só os efeitos danosos ao bem segurado são aparentes, como o bem

\footnotetext{
150، O dolo, na relação jurídica securitária, pode ocorrer no momento da contratação do seguro (por exemplo, com a falsificação dos riscos oferecidos ao segurador, o que desnaturará por completo a alocação dos recursos das economias coletivas), ou no momento de ocorrência do sinistro e de seu comunicado ao segurador, para a exigência de indenização (por exemplo, com a causação ou caracterização errônea do evento ou o exagero do valor da reclamação),". TZIRULNIK, Ernesto e OCTAVIANI, Alessandro, op. cit., p. 6.
} 
em si é passível de exame para que se faça juízo valorativo sobre a causa do dano e sobre a culpabilidade do agente.

Em contrapartida, no seguro de responsabilidade, o modo como a conduta do beneficiário da apólice repercute sobre o interesse segurado não se verifica desde logo no plano fático, tampouco é possível a imediata subsunção da conduta aos efeitos por ela produzidos, como ora demonstrado.

Desta feita, no seguro de responsabilidade civil de administradores, parte da indenização costuma ser paga pela seguradora independente da apreciação de culpa ou dolo do segurado no âmbito societário. Como explicado, as indenizações relativas a este seguro são basicamente de duas naturezas: (i) custos de defesa; e (ii) indenização pelos danos causados a terceiro, conforme apurado em processo administrativo, judicial ou arbitral.

Neste sentido, em virtude da massificação das operações de seguro e da dinâmica dos riscos subjacentes aos seguros, seria inviável atrelar o pagamento dos custos de defesa à comprovação de que o segurado não agiu com dolo ou culpa. Portanto, observadas as condições previstas na apólice e, estando o risco materializado incluído no alcance da cobertura contratada, a seguradora deverá pagar os custos de defesa incorridos pelo segurado $^{151}$.

Já as indenizações securitárias que têm por objetivo cobrir o valor dos danos determinado por decisão em sede administrativa, civil ou arbitral, geralmente dependem da apuração da responsabilidade do administrador no âmbito societário ${ }^{152}$.

Esta mecânica de indenização securitária pode, em alguns casos, sofrer algumas variações. Conforme informado pelas seguradoras entrevistadas, há casos em que as

\footnotetext{
${ }^{151}$ De acordo com Isaac Halperin, a principal obrigação da seguradora não é indenizar, mas sim assumir o risco. Contudo, a obrigação de indenizar o sinistro se impõe na medida em que se realize o sinistro dentro das condições previstas na lei e no contrato. Nas palavras do autor: "Su obligación (del asegurador) cierta es la de pagar si el siniestro se produce en las condiciones previstas en la ley e en el contrato." HALPERIN, Isaac, op. cit, v.2, p. 502.

${ }^{152}$ Adolfo Paolini assinala que, exceto com relação aos custos de defesa, a obrigação de indenizar da seguradora não surge até que a responsabilidade do segurado seja apurada. Nas palavras dos autores: “[...] the primary contractual obligation on the part of the insurer to indemnify the insured does not arise until the director's precise liability is ascertained.” PAOLINI, Adolfo; NAMBISAN, Deepak, op. cit., pp. 40.
} 
seguradoras pagam ao segurado os valores devidos nos termos de uma sentença condenatória de primeira instância mesmo que ela confirme dolo do segurado. Isto porque tal decisão poderá ser revertida futuramente. Naturalmente, fica o segurado obrigado a devolver tais quantias caso a sentença transitada em julgado confirme a decisão de primeira instância.

\subsubsection{ATO DO ADMINISTRADOR SOB A PERSPECTIVA SECURITÁRIA}

Ao segurado, incumbem deveres e obrigações previstos no contrato de seguro, cujo volume e características variam de acordo com o risco assumido: quanto menor a possibilidade de a conduta do segurado afetar o risco, em menor número serão seus deveres e obrigações ${ }^{153}$. O cumprimento de tais deveres e obrigações são condição sine qua non para a concretização do dever de indenizar da seguradora.

Segundo Isaac Halperin, “o cumprimento do dever do segurado é um pressuposto da eficácia da indenização ou do seu aumento ou para alguma obrigação de fazer da seguradora" ${ }^{154}$. Como assinala o autor, estes deveres e obrigações variam de acordo com a possibilidade de afetação do risco, mas consistem fundamentalmente em (i) obrigação de pagar o prêmio; (ii) dever de manter o estado do risco; (iii) dever de informar o acontecimento do sinistro e os danos sofridos; e (iv) dever de evitar ou mitigar os danos. ${ }^{155}$

Como se nota, as obrigações do segurado relacionam-se majoritariamente ao risco, seja no momento em que faz declarações quando da contratação do seguro, seja no decorrer do contrato, seja ao longo de sua gestão.

Especificamente em termos de seguro de responsabilidade civil de administradores, apesar de o risco empresarial não se confundir com o risco de sinistro (aqui caracterizado pela efetiva reclamação de terceiro ${ }^{156}$ ), pode haver sobreposição destes riscos na medida

\footnotetext{
${ }^{153}$ Conforme HALPERIN, Isaac, op. cit., v.1, p. 371.

${ }^{154}$ Nos dizeres do autor: “...el cumplimiento de la carga es el presupuesto para la eficacia de la prestación o su extensión o para algún hacer del asegurador.” HALPERIN, Isaac, op. cit., v.1, p. 373.

${ }^{155}$ Conforme HALPERIN, Isaac, op. cit., v.1, p. 390 e ss.

156، O sinistro de responsabilidade civil exsurge quando o patrimônio do segurado é ameaçado de diminuição por uma reclamação indenizatória apresentada pelo terceiro lesado, judicial ou extrajudicialmente, seja ou não fundada a reclamação.” DIAS, José Aguiar, Da responsabilidade Civil, Vol. II, Rio de janeiro: Forense, 1997, p. 843.
} 
em que a assunção desmesurada de risco empresarial pode representar um agravamento do risco sob a ótica securitária (aumento do risco de sinistro).

O risco próprio do seguro de responsabilidade civil de administradores é aquele relativo à possibilidade de ser o administrador compelido a indenizar terceiro por um dano causado por seu ato. Assim, a materialização do risco depende da efetiva instauração de processo administrativo ou da propositura de ação por terceiro.

Como a materialização do risco está condicionada ao exercício de um direito titulado por terceiro, a minoração ou majoração do risco segurado, no caso do seguro em análise, parece somente poder se processar em relação à conduta do administrador sob a perspectiva societária.

Isto porque o terceiro pode optar por não recorrer aos meios legais de que dispõe para ressarcimento aos prejuízos causados. Em outras palavras, o risco do seguro de responsabilidade civil de administradores, mesmo que haja dano ao terceiro comprovadamente causado pelo administrador, pode nunca chegar a se materializar caso o terceiro lesado opte por não pleitear o que lhe seria devido.

Ademais, pelo $\mathrm{CC} / 02^{157}$, o beneficiário do seguro deve agir sempre de modo a mitigar o risco e evitar seu agravamento.

O problema que se coloca aqui é a aferição do agravamento do risco, não só porque o risco do seguro muitas vezes se mistura ao risco empresarial, mas também porque existem situações em que, embora seja possível determinar um ato ou fato concreto que atinge o risco, as seguradoras brasileiras divergem quanto ao efetivo incremento do risco e quanto à efetiva alteração de seu estado inicial (vide seção 6.2.2.2).

Por fim, vale ressaltar que todo o comportamento do segurado com relação ao risco (manutenção de seu estado, comunicação de seu agravamento, prevenção e mitigação dos danos) deve ter por objetivo estimulá-lo a evitar a materialização do risco. Este

\footnotetext{
${ }^{157}$ Art. 769 - O segurado é obrigado a comunicar ao segurador, logo que saiba, todo incidente suscetível de agravar consideravelmente o risco coberto, sob pena de perder o direito à garantia, se provar que silenciou de má-fé.
} 
comportamento é imprescindível para que seja legítimo seu direito à garantia e para que ela não resulte em seu enriquecimento ilícito.

Confiram-se os ensinamentos de Vera Helena de Mello Franco sobre o embasamento e a importância do princípio indenitário em matéria securitária:

O fundamento (do princípio indenitário) está na finalidade de manter o segurado interessado em que o sinistro não ocorra. Por isto é que o seguro de danos somente é válido quando o segurado não tem interesse na realização do risco. $\mathrm{O}$ desrespeito ao princípio acarretará a perda da indenização $[\ldots]^{158}$.

A prevalência deste princípio busca assegurar que o segurado não se mostre indiferente ao risco e à consequente materialização do sinistro. No campo do seguro de responsabilidade civil de administradores, por não ser o objeto do seguro um bem palpável, a verificação do comportamento do beneficiário do seguro no sentido de efetivamente evitar o sinistro é bastante complexa.

Neste ponto, não se está sugerindo que o administrador teria propriamente interesse no sinistro, parecendo até ilógico supor que ele desejasse o surgimento de uma reclamação. Todavia, novamente por conta da subjetividade do comportamento do administrador, coloca-se uma tênue diferença entre não desejar que o sinistro ocorra e efetivamente portar-se de forma a preveni-lo.

Não por outro motivo, a lei e o próprio contrato de seguros colocam uma série de hipóteses em que a aplicabilidade do seguro é afastada. $\mathrm{O}$ intuito, além de proteger a base segurada e garantir o bom funcionamento do mercado, parece-nos ser o de minimizar o risco moral, desestimulando o administrador a agir em desalinho com seus deveres, seja do ponto de vista societário, seja do ponto de vista securitário.

\footnotetext{
${ }^{158}$ FRANCO, Vera Helena de Mello. Contratos - direito civil e empresarial. $2^{\text {a }}$ ed. São Paulo: Revista dos Tribunais, 2011, p. 316.
} 


\section{A APLICABILIDADE DO SEGURO DE RESPONSABILIDADE CIVIL DE ADMINISTRADORES NO ÂMBITO DA ADMINISTRAÇÃO DAS COMPANHIAS}

\subsection{ASPECTOS GERAIS RELATIVOS À APLICABILIDADE DO SEGURO}

Diversas questões cercam a aplicabilidade do seguro de responsabilidade civil de administradores. Para fins deste trabalho, o termo "aplicabilidade" deve ser entendido em sentido estrito, especificamente no que se refere ao cabimento da cobertura securitária diante da situação fática que ensejou o acionamento do seguro examinado.

Tendo em vista que um dos objetivos aqui pretendidos é discutir se eventualmente os administradores não poderiam se valer do seguro para atuar de forma menos diligente, o exercício a que este trabalho se propõe consiste na observação das hipóteses de aplicação do seguro de responsabilidade civil dos administradores para verificar se e em que medida este seguro agrava o risco moral, bem como para discutir sua admissibilidade no Direito brasileiro.

Como dito anteriormente, conquanto não seja possível exaurir todas as situações fáticas em que se discute a aplicabilidade do seguro, a seleção das hipóteses objeto deste trabalho levou em conta (i) a frequência com que tal situação ocorre no mercado brasileiro; e (ii) o número de reclamações e discussões envolvendo tal situação.

Como mencionado na introdução, este seguro ainda é bastante incipiente no Brasil, razão pela qual não há um número expressivo de precedentes administrativos ou judiciais que tratem da matéria. Ademais, como a contratação deste seguro não é de caráter público (exceto pela obrigação das companhias de divulgá-lo em seu formulário de referência), não foi possível encontrar levantamentos ou dados estatísticos oficiais e de acesso público no Brasil que indicassem as situações mais recorrentes no cenário nacional.

Sendo assim, a amostragem de situações selecionadas para análise baseou-se (i) na experiência estrangeira de países como Estados Unidos, Inglaterra, Canadá e Austrália; e 
(ii) nas informações prestadas e nos levantamentos de uso exclusivamente interno gentilmente cedidos pelas seguradoras ACE, CHUBB e ZURICH.

Nos Estados Unidos, Inglaterra, Canadá e Austrália, no que tange à aplicabilidade do seguro, estão entre os temas mais debatidos ${ }^{159}$ : (i) cobertura de penalidades e multas; (ii) momento da notificação de sinistro; (iii) individualização de condutas e solidariedade entre os administradores para fins do seguro; e (iv) reclamações de um segurado contra outro segurado e reclamações envolvendo tomador (companhia) e segurado, bem como acionista e segurado. No Brasil, os temas mais recorrentes seguem esta mesma linha.

\subsubsection{METODOLOGIA ADOTADA}

A análise dos aspectos práticos atinentes ao seguro de responsabilidade civil de administradores no Brasil enfrenta alguns entraves. Não é possível mensurar, por exemplo, o número total de companhias nacionais que contrata este tipo de cobertura, visto que somente as sociedades de capital aberto estão obrigadas a informar a existência do seguro em questão.

Ademais, por se tratar de um ramo relativamente novo no país, praticamente inexistem julgados sobre o tema ${ }^{160}$; em sua maioria, as decisões que fazem referência à matéria são da esfera administrativa, conforme examinadas na seção 6.2.2.

Ressalte-se ainda que, segundo informações das seguradoras ACE e ZURICH, os pontos controvertidos relacionados à aplicabilidade do seguro que o mercado securitário brasileiro tem enfrentado, em regra, acabam sendo discutidos com os tomadores e segurados e dirimidos mediante acordo amigável. Por se tratar de um seguro cuja ascensão mais significativa no Brasil data do ano de 2010, é provável que ainda não tenha

\footnotetext{
${ }^{159}$ Conforme BITTLE, Lyndon F., SUTHERLAND, J. Michael, BARNHOUSE, Shelbi, POCSIK, Stephen. Insurance and Indemnification of Directors and Officers: Avoiding Pitfalls, 2011, p. 203. Disponível em $<$ http://www.ccsb.com/pdf/Publications/Insurance/Avoiding_Pitfalls_2011.pdf $>$. Acesso em 15.10.2012; BITTLE, Lyndon F., An Overview of Insurance Coverage Disputes. National Business Institute Seminar, 2008. Disponível em <http://www.ccsb.com/pdf/Publications/Insurance/Ins_coverage_disputes.pdf $>$. Acesso em 15.10.2012; DONLEY, Steven, KENT, Nigel P. Directors and Officers Liability in Canada: A Review of Exposures and Coverages Available under D\&O Policies. 2008. Disponível em $<$ https://www.cwilson.com/publications/insurance/directors-officers-liability-in-canada.pdf $>$. Acesso em 15.10.2012; MERKIN, Robert. Directors' and Officers' Insurance and the Global Financial Crisis. Australian Insurance Law Association (Geoff Masel Memorial Lectures), Australia, 2009.

${ }^{160}$ Vide seção 6.2.3.3.
} 
transcorrido tempo suficiente para que as questões aqui examinadas pudessem ter sido discutidas com maior profundidade pelos reguladores e magistrados.

Neste sentido, para viabilizar o exame dos aspectos práticos e superar os entraves supracitados e, a exemplo da metodologia utilizada nos estudos com companhias canadenses $^{161}$ (que estão obrigadas a divulgar informações sobre $\mathrm{o}$ seguro de responsabilidade de seus administradores), este trabalho adotou a seguinte metodologia: (i) amostragem de companhias que compõem o Índice Bovespa (Ibovespa) e que contratam o seguro; (ii) exame das situações práticas mais recorrentes no mercado brasileiro, de acordo com (a) levantamento realizado pela seguradora ZURICH em 2011; e (b) informações prestadas pelas seguradoras ACE, CHUBB e ZURICH.

Conforme informações no site da BM\&FBovespa ${ }^{162}$, em termos de liquidez, as ações integrantes da carteira teórica do Ibovespa respondem por mais de $80 \%$ do número de negócios e do volume financeiro verificados no mercado à vista (lote-padrão) da bolsa brasileira. Dados os elevados níveis de liquidez que apresentam, as companhias que compõem o Ibovespa não só têm as ações mais negociadas, como possivelmente são as mais atrativas aos pequenos investidores ${ }^{163}$, motivo pelo qual acreditamos ser razoável a utilização destas entidades como parâmetro para a pesquisa aqui proposta.

Para o levantamento dos casos concretos mais recorrentes no Brasil envolvendo a aplicabilidade do seguro, foram entrevistadas ACE, CHUBB e ZURICH.

Considerando a experiência prática adquirida por estas seguradoras no mercado securitário brasileiro em matéria de seguro de responsabilidade civil de administradores e, em virtude da já mencionada escassez de precedentes jurisprudenciais e de doutrina pátria sobre o tema, acredita-se que a contribuição destas seguradoras na prestação de

\footnotetext{
${ }^{161}$ Conforme CORE, John E. The Directors' and Officers' Insurance Premium: An Outside Assessment of the Quality of Corporate Governance, maio/2000. Disponível em <http://ssrn.com/abstract=229803> e KANG, Christine. Directors' and Officers' Insurance: Ordinary Corporate Expense or Valuable Signaling Device?, maio/2011. Departamento de economia da Universidade de Stanford. Disponível em $<$ http://economics.stanford.edu/files/Kang_HThesis2011.pdf>. Acesso em 15.10.2012.

${ }^{162}$ Disponível em <http://www.bmfbovespa.com.br/indices/ResumoIndice.aspx?Indice=Ibovespa\&Opcao $=0$ \&idioma $=$ pt-br $>$. Acesso em 15.10.2012.

${ }^{163}$ Conforme levantamento dos valores de prêmios recebidos ano a ano (a partir de 2003) pelas seguradoras brasileiras que atuam no ramo mediante consulta ao Sistema de Estatísticas da SUSEP disponível em

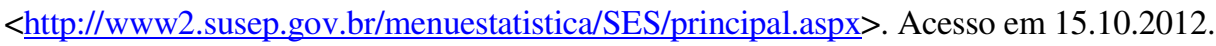


informações sobre o seguro examinado é decisiva, especialmente no que se refere às questões práticas relativas à sua aplicabilidade.

\subsubsection{APLICAÇÃO DO SEGURO DE RESPONSABILIDADE CIVIL DE ADMINISTRADORES NO MERCADO BRASILEIRO}

Das 69 companhias que compõem o Ibovespa, 63 (cerca de 91\%) declararam, em seu formulário de referência, possuir seguro de responsabilidade civil de administradores. Estes números indicam que, só em 2012, a contratação do seguro cresceu aproximadamente 13\%, haja vista que, em 2011, 54 (cerca de 78\%) destas companhias possuíam o seguro.

Antecipando a expansão do segmento, em 2011, a ZURICH realizou um levantamento interno (baseado na carteira de clientes composta por sociedades de capital aberto que contrataram seguro de responsabilidade civil para seus administradores) dos tipos de reclamações mais frequentes que resultam no acionamento deste seguro.

Como demonstra o gráfico a seguir, 60\% das reclamações contra os diretores e conselheiros foram de autoria de órgãos reguladores e fiscalizadores (segundo a seguradora, notadamente a CVM). Apesar de não terem disponibilizado as estatísticas deste mesmo levantamento, as seguradoras ACE e CHUBB confirmaram que mais da metade das demandas contra os administradores decorrem de procedimentos instaurados pela $\mathrm{CVM}^{164}$.

\footnotetext{
${ }^{164}$ Vale lembrar que, para fins deste estudo, conforme explicado anteriormente, a responsabilidade no âmbito administrativo está sendo examinada exclusivamente à luz da competência da CVM.
} 


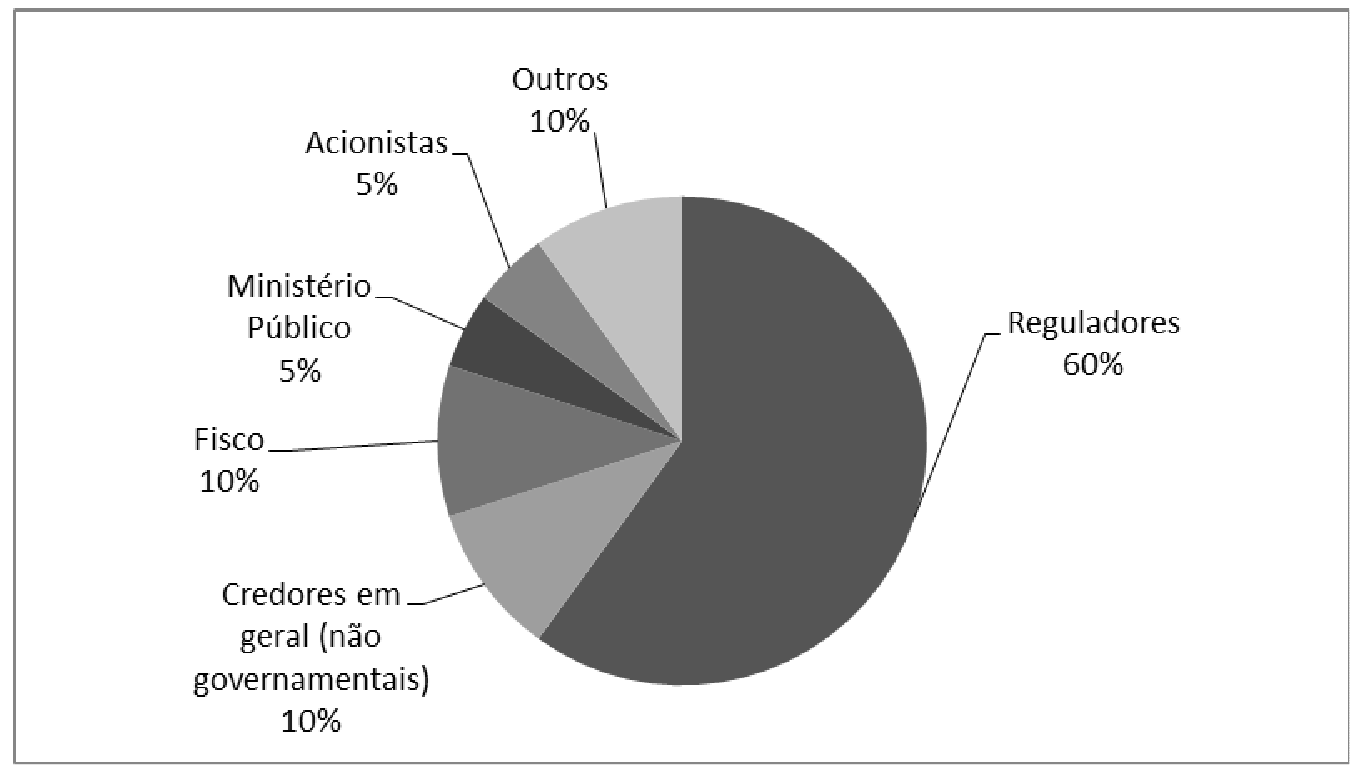

Fonte: Zurich Brasil Seguros S.A. (2011)

Diferentemente do Brasil, nos Estados Unidos da América, a contratação do seguro volta-se primordialmente à proteção contra reclamações dos acionistas ${ }^{165}$. Os números comprovam os estudos: uma pesquisa realizada nos Estados Unidos em $2011^{166}$ da qual participaram 401 entidades, $45 \%$ informaram que o tipo de reclamação mais recorrente que as leva a acionar o seguro são ações individuais de responsabilidade movidas por acionistas e $42 \%$ informaram ser mais recorrentes as ações sociais.

A razão provável desta diferença está nos sistemas de controle concentrado e difuso. No Brasil, por ainda viger um sistema de controle e de capital eminentemente concentrados, as ações de responsabilidade civil movidas por acionistas contra os administradores são relativamente escassas. Ademais, o fato de muitos acionistas integrarem o quadro administrativo das companhias também contribui para que o número destas ações seja ainda menor (vide seção 5.4.4).

\footnotetext{
${ }^{165}$ Conforme Christine Kang: "Directors and officers most often seek protection against shareholder claim." KANG, Christine, op. cit., p. 11. Vide também Baker e Griffith: "For public corporations, the dominant source of D\&O risk, both in terms of claims brought and liability exposure, is shareholder litigation." BAKER, Tom; GRIFFITH, Sean J., Predicting Corporate Governance Risk: Evidence from the Directors' and Officers' Liability Insurance Market. Chicago Law Review, v. 74, 2007, p. 494; e John E. Core: "In both Canada and the U.S., roughly one-half of D\&O claims are brought by shareholders (the remainder by employees, customers, competitors, regulators, and other third-parties). CORE, John, op. cit., p. 5.

${ }^{166}$ Conforme 2011 Directors and Officers (D\&O) Liability Survey realizada por Towers Watson. Disponível em <http://www.towerswatson.com/assets/pdf/6532/Towers-Watson-Directors-and-Officers-Liability-2011Survey.pdf $>$. Acesso em 15.10.2012.
} 
É importante salientar que esta característica ainda marcante no cenário brasileiro também repercute no âmbito do seguro, haja vista as restrições à cobertura de reclamações feita por um segurado contra outro segurado (i.e., em regra, não está amparada pelo seguro, por exemplo, uma reclamação de um acionista-administrador segurado contra outro administrador também segurado), como expliacado na sequência.

\subsection{ANÁLISE CIRCUNSTANCIADA DA APLICABILIDADE DO SEGURO}

\subsubsection{APLICAÇÃO IMEDIATA}

Justamente por ser dificultosa a apreciação da culpa ou dolo do administrador, sobretudo quando se fala em responsabilização pessoal, não poderia a concessão de cobertura securitária ficar completamente atrelada ao juízo de culpabilidade sob a ótica do direito societário, sob pena de inviabilizar completamente as operações de seguro de responsabilidade civil de administradores.

Como visto, as operações de seguro são massificadas e a própria dinamicidade da atividade empresarial securitária tornaria impraticável a operacionalização do seguro caso o pagamento das indenizações securitárias ficasse condicionado à prévia aferição de culpa ou dolo do segurado.

Logo, a obrigação de indenizar da seguradora verifica-se a partir do momento em que o segurado comunica a seguradora da reclamação de terceiro. Logicamente, neste momento, ainda não são conhecidos os valores atribuídos ao dano do terceiro (nem tampouco se o administrador efetivamente os deve); todavia, a reclamação, por si só, já cria uma despesa imediata para o segurado (custos de defesa), a qual deve ser indenizada independente do desfecho da reclamação. Por este motivo, a praxe do mercado é adiantar os custos de defesa ao segurado.

Isto não significa, contudo, que o seguro cubra deliberadamente qualquer ato do administrador. Pelo contrário: a seguradora, antes de autorizar o pagamento da 
indenização, realiza uma minuciosa avaliação que consiste no chamado processo de regulação do sinistro ${ }^{167}$.

Concluído o processo de regulação do sinistro e, estando este último amparado pela cobertura prevista na apólice, a indenização securitária já é concedida.

Ressalte-se que o fato de o seguro operar desta forma não prejudica a base de segurados ou o mercado, nem tampouco privilegia o segurado cuja conduta eventualmente tenha sido dolosa, pois o contrato, neste caso, será considerado nulo, conforme ensina Ernesto Tzirulnik:

[...] o segurador tende, seguindo o preceito legal, a encarar como verdades as declarações do segurado. Se este age com dolo, em um primeiro momento, é mais do que óbvio que o segurador emitirá declaração de vontade viciada, uma vez que pensa estar ouvindo a verdade. Tal situação é suficiente para fulminar o contrato e as obrigações que dele sobrevieram ${ }^{168}$.

Como visto, visando a evitar que a seguradora acabe por indenizar o segurado que age com dolo, à seguradora é assegurado o direito a reembolso das quantias pagas a título de adiantamento de custos de defesa ou de indenização se restar provado o dolo do segurado, seja por fraude ao seguro, seja no caso de condenação do administrador por ato doloso no exercício da gestão.

\subsubsection{ALGUMAS RESTRIÇÕES E LIMITES À APLICABILIDADE DO SEGURO}

Conforme assinalado no início deste Capítulo 6, não há estudos oficiais no país, nem tampouco doutrina e jurisprudência brasileiras que discutam os problemas de ordem prática envolvendo o seguro de responsabilidade civil de administradores. Neste sentido,

\footnotetext{
${ }^{167}$ Segundo a seguradora ZURICH, após a comunicação do sinistro, tem início o processo de "regulação do sinistro", pelo qual a seguradora avaliará circunstâncias e documentação das reclamações. Para tanto, o segurador deve: (i) notificar a seguradora por escrito, com rico detalhamento da ocorrência, incluindo (a) lugar, data, horário e descrição sumária do ocorrido ou da reclamação, natureza dos danos alegados ou potenciais e suas possíveis consequências; (b) nome e dados dos demandantes e de eventual testemunha; (c) data e maneira pela qual o tomador ou segurados tomaram ciência da reclamação; e (d) natureza dos danos e/ou das lesões corporais; (ii) fornecer cópia integral da reclamação; (iii) providenciar ao menos duas propostas de honorários dos profissionais que serão envolvidos (advogados, contabilistas, etc); (iv) fornecer documentos adicionais que a seguradora venha a solicitar.

${ }^{168}$ TZIRULNIK, Ernesto e OCTAVIANI, Alessandro, op. cit., p. 7.
} 
esta pesquisa leva em conta a experiência estrangeira sobre a matéria e as informações prestadas pelas seguradoras ACE, CHUBB e ZURICH.

\subsubsection{MULTAS E PENALIDADES CIVIS}

Em regra, as apólices de seguro de responsabilidade civil preveem que estão cobertos pelos seguros os custos de defesa, custos de investigação e prejuízos financeiros (e.g., condenações pecuniárias, acordos judiciais ou extrajudiciais) incorridos pelo administrador em decorrência de processos administrativos e judiciais.

Geralmente, estão expressamente excluídas do âmbito da cobertura as multas e penalidades civis (assim entendidas, para fins do seguro, todas aquelas que não tenham caráter penal) impostas ao administrador. Antes de terem início os debates acerca da possibilidade de se segurarem multas, algumas seguradoras ofereciam extensão de cobertura especial para determinadas multas e penalidades, as quais eram contratadas separadamente e implicavam incremento do valor total do prêmio.

A viabilidade jurídica da contratação de extensão de cobertura para ressarcimento dos valores devidos a tais títulos tem sido intensamente debatida por seguradoras e reguladores.

\section{(A) Posicionamento da SUSEP}

O plano padronizado dos seguros de responsabilidade civil geral disponibilizado pela SUSEP'169 estabelece que a seção de "riscos excluídos" da apólice desta modalidade deverá estipular, dentre outros riscos não amparados pelo seguro, que o contrato não indenizará, nem reembolsará as multas, de qualquer natureza, impostas ao segurado, bem como as indenizações punitivas e/ou exemplares às quais seja condenado pela justiça.

Ocorre que a própria SUSEP, ciente das especificidades do seguro de responsabilidade civil de administradores, retirou-o da categoria geral de seguros de

\footnotetext{
${ }^{169}$ Conforme Circular SUSEP n 437 de 14 de junho de 2012, conforme alterada.
} 
responsabilidade civil geral ${ }^{170}$, o que significa que, a princípio, a impossibilidade de indenizar multas não se aplica a este seguro.

Ademais, exceto pela Circular SUSEP 336/07171, a SUSEP não editou normativos específicos para as particularidades atinentes ao seguro de responsabilidade civil de administradores, nem tampouco tratou de limitações de cobertura ou exclusões que deveriam ser tidas como "padrão" nos contratos de seguro desta modalidade.

A despeito da inexistência de uma vedação regulatória ao oferecimento de cobertura de multas e penalidades no âmbito do seguro de responsabilidade civil de administradores, conforme informações prestadas pelas seguradoras ACE e ZURICH, a SUSEP tem se negado a aprovar as condições gerais das apólices que ofereçam este tipo de cobertura $^{172}$, com base em um parecer da Procuradoria de Assuntos Societários e Regimes Especiais da SUSEP de 2006.

As seguradoras informaram ainda que a SUSEP ainda não colocou o assunto em discussão com todo o mercado, tendo apenas indeferido os pedidos de aprovação de cobertura de multa apresentados pelas seguradoras.

Por não se tratar de um parecer público, seu conteudo não foi amplamente divulgado. Não obstante, uma das seguradoras entrevistadas gentilmente cedeu uma cópia do parecer exclusivamente para fins acadêmicos, tendo ocultado os dados do processo e das partes envolvidas. A íntegra do documento está anexa a este trabalho na forma do Anexo I.

Trata-se do posicionamento da autarquia com relação a uma proposta de clausulado para um "seguro de custas judiciais, honorários advocatícios e multas despendidas por administradores de entidade fechada de previdência complementar". Em que pese o seguro de responsabilidade de administradores de entidades desta natureza receber um tratamento

\footnotetext{
${ }^{170}$ Conforme Circular SUSEP n ${ }^{\circ} 437$ de 14 de junho de 2012, Art. $6^{\circ}$ - O Seguro de Responsabilidade Civil Geral, de contratação facultativa, constitui um ramo específico, e cobre os riscos de responsabilização civil por danos causados a terceiros [...].§ $2^{\circ}$.Os riscos de responsabilização civil vinculados ao exercício de cargos de Direção e/ou Administração em empresas são enquadrados em outro ramo de seguro, denominado seguro de responsabilidade civil de diretores e administradores de empresas (RC D\&O).”

${ }^{171}$ Vide seção 4.2.4.

${ }^{172}$ Conforme Circular SUSEP no $336 / 07$, Art. $2^{\circ}$ - As sociedades seguradoras deverão submeter à SUSEP, para fins de análise e arquivamento, as condições contratuais, e as respectivas notas técnicas atuariais, dos planos de seguros de responsabilidade civil que utilizarem apólices à base de reclamações.
} 
ligeiramente diferenciado por força da regulamentação previdenciária específica, neste trabalho, a discussão será focada na porção do parecer que versa sobre a cobertura securitária para multas em geral.

Da argumentação do Senhor Procurador Paulo Antonio Costa de Almeida Penido, que se posiciona contrariamente à cobertura de multas, vale destacar os seguintes pontos:

21. A apuração do seguro em epígrafe deixa imune o infrator, sendo ele, futuramente, reembolsado pelo valor pago.

22. Dessa forma, haverá um desestímulo ao não respeito (sic) as leis, o que é impraticável.

23. Cabe ainda salientar que a multa pode estar, muitas vezes, em desproporção com o dano ocorrido, sendo mais benéfico ao segurador (sic) receber a multa do que arcar com as consequências do seu ato injusto. (página 5)

Inicialmente, afigura-se equivocada a percepção de que o seguro imuniza o infrator, pois o fato de o seguro reparar seu patrimônio não elimina o risco reputacional, nem a criação de um ônus sobre seu currículo que pode (i) afetar diretamente sua empregabilidade; (ii) impedi-lo de exercer suas funções por restrições impostos pelas autoridades a que as companhias estão sujeitas (e.g., inabilitação para o exercício do cargo); (iii) colocar em dúvida sua idoneidade; e (iv) influir no valor do prêmio quando da contratação de novo seguro ${ }^{173}$.

Ademais, os desdobramentos de uma condenação, ainda que esta se restrinja ao pagamento de uma pena pecuniária, não se resumem ao impacto patrimonial. Por isso, não há que se falar que seria mais benéfico honrar a multa em vez de arcar com as consequências do ato, visto que a multa não exime o administrador das consequências de seu ato. Pelo contrário, a sua responsabilização independe em absoluto da existência do seguro e será devidamente apreciada no âmbito do procedimento cabível.

A este respeito, Antonio Roncero Sánchez esclarece que a contratação do seguro não constitui uma hipótese de exoneração da responsabilidade dos administradores, mas

\footnotetext{
${ }^{173}$ De acordo com Martin M. Boyer, "If past behavior is any indication of current behavior, any information related to the risk of the insured gathered in the past by the insurance company will be used as a signal regarding the current risk of the insured." BOYER, Martin M. Is the Demand for Corporate Insurance a Habit? Evidence from the Directors' and Officers' Insurance. In Série Scientifique - Centre Interuniversitaire de recherché en analyse des organisations. Montréal, 2003, p.8.
} 
apenas uma limitação da mesma em sentido econômico. A diferença é que o administrador segurado responde exatamente da mesma forma e pelas mesmas condutas que o administrador não segurado, mas aquele compartilha, em maior ou menor medida, as consequências de sua responsabilidade com outro sujeito, a companhia seguradora.

$\mathrm{O}$ autor esclarece ainda que o seguro não fere o caráter imperativo do regime jurídico, pois não possibilita sua derrogação por vontade das partes, ou seja, não cabe sua alteração no que diz respeito à exoneração, limitação ou redução da responsabilidade legalmente imposta ${ }^{174}$.

\section{(B) Posicionamento da CVM}

No Brasil, não raro as indenizações decorrentes de procedimentos iniciados pela CVM são pagas com recursos provenientes do seguro de responsabilidade.

Até o momento, a CVM não se manifestou formalmente quanto à cobertura securitária para multas administrativas por ela impostas, mas, a julgar por seu posicionamento com relação à aplicabilidade do seguro para pagamento de montantes previstos em termos de compromisso, é provável que ela não se oponha à cobertura securitária para pagamentos a ela devidos, seja a que título for.

A autarquia inclusive já se mostra favorável a propostas de termo de compromisso em que o pagamento da quantia devida pelo administrador fica condicionado à indenização securitária, como no exemplo a seguir:

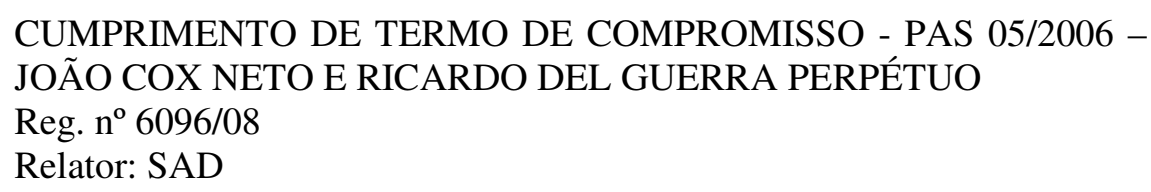

\footnotetext{
${ }^{174}$ Nos dizeres do autor: "La contratación del seguro no constituye un supuesto de exoneración de la responsabilidad de los administradores sino únicamente una limitación de la misma en sentido económico (el administrador asegurado responde exactamente igual y por las mismas conductas que el no asegurado si bien aquél comparte en mayor o menor medida las consecuencias patrimoniales de su responsabilidad con otro sujeto, la compañía asseguradora. Junto a ello, el carácter imperativo del régimen legal significa que no cabe su derogación por voluntad de las partes, es decir, no cabe su alteración en lo que respecta, al menos, a una liberación, limitación o reducción de la responsabilidad legalmente impuesta." SÁNCHEZ, Antonio Roncero, op. cit., p. 5.
} 
Trata-se de apreciação de cumprimento das condições constantes no Termo de Compromisso celebrado por João Cox Neto e Ricardo Del Guerra Perpétuo, aprovado na reunião de Colegiado de 08.07.08, no âmbito do PAS 05/2006.

O Superintendente Geral esclareceu que os pagamentos previstos no Termo de Compromisso foram efetuados diretamente pela Amazônia Celular S.A. e Telemig Celular S.A. - companhias nas quais os compromitentes eram administradores à época dos fatos objeto do presente processo -, tendo em vista que, segundo ajustado, o pagamento seria feito com recursos provenientes de seguro de responsabilidade civil de administradores.

A propósito dos termos de compromisso, as seguradoras entrevistadas confirmaram que também tem sido amplamente discutida a equiparação do termo de compromisso à multa. Prevalecendo esta tese, as quantias previstas no termo também estariam excluídas do âmbito da cobertura.

Para debater a questão, cabe retomar a análise da natureza do termo de compromisso discutida na seção 5.4.3.3. O termo de compromisso tem, em sentido amplo, um caráter majoritariamente indenizatório (seja de um determinado terceiro, seja do mercado como um todo).

Ademais, ele não tem caráter de multa, pois, além de ter sua função bem delineada pela Lei 6.385/76 e pela Deliberação da CVM n 390 de 8 de maio de 2001, a celebração de termo de compromisso implica suspensão do processo administrativo sancionador ${ }^{175}$.

Considerando que as penalidades como a de multa somente podem ser aplicadas no âmbito de um processo sancionador, não se pode dizer que o termo de compromisso equivalha a uma multa, haja vista que sua negociação se processa fora do âmbito do processo administrativo (ora suspenso por força da proposta de termo de compromisso).

A nosso ver, conferir ao termo de compromisso o caráter de multa significaria extrapolar a interpretação da lei e dos normativos aplicáveis, bem como as finalidades a

\footnotetext{
${ }^{175}$ Art. 11, parágrafo $5^{\circ}$ da Deliberação CVM no 390/01 - A Comissão de Valores Mobiliários poderá, a seu exclusivo critério, se o interesse público permitir, suspender, em qualquer fase, o procedimento administrativo instaurado para a apuração de infrações da legislação do mercado de valores mobiliários, se o investigado ou acusado assinar termo de compromisso, obrigando-se a: I - cessar a prática de atividades ou atos considerados ilícitos pela Comissão de Valores Mobiliários; e II - corrigir as irregularidades apontadas, inclusive indenizando os prejuízos".
} 
que se destina o termo de compromisso, quais sejam (i) fazer cessar a prática de atividades ilícitas no âmbito do mercado de capitais; e (ii) corrigir as irregularidades apontadas, inclusive reparando os prejuízos a terceiros específicos e/ou ao mercado.

Ainda assim, alguns defendem que os valores previstos no termo de compromisso teriam cunho exemplar ${ }^{176}$ (o que os aproximaria da condição de multa), devendo ter por finalidade também o desestímulo à prática de infrações.

Como a questão ainda não foi pacificada, esta é uma hipótese típica de possível restrição à aplicabilidade do seguro no âmbito administrativo.

\section{(C) Experiência Estrangeira}

Aproveitando a experiência estrangeira sobre a matéria, nota-se que houve uma paulatina mudança de paradigma acerca das coberturas para multa. A literatura norteamericana aponta que a regra costumava ser de exclusão de cobertura para multas e penalidades, independente de sua natureza. Com o tempo, algumas seguradoras passaram a oferecer cobertura para multa e penalidades civis, excetuadas as multas aplicadas na esfera penal $^{177}$.

Atualmente, a delimitação da cobertura para multa fica a critério das partes no ato da contratação do seguro. Se antes as apólices excluíam quaisquer multas ou penalidades indistintamente, hoje há espaço para negociação desta cobertura (por exemplo, para multas de cunho regulatório), contanto que ela seja segurável nos termos da lei ${ }^{178}$.

\footnotetext{
${ }^{176}$ Conforme Análise da Proposta de Termo de Compromisso apresentada pelo diretor da CVM, Pedro Oliva Marcilio de Sousa, nos autos do PAS CVM SP 2005/0128 de 19 de abril de 2006: "a orientação recente do Colegiado tem sido no sentido de que, além de cessar a prática de atividades ou atos ilícitos, corrigir as irregularidades e indenizar os prejuízos, requisitos mínimos estabelecidos em lei para a celebração do Termo de Compromisso, as prestações em termos de compromisso não destinadas ao reembolso dos prejuízos devem consistir em pagamento à CVM em valor suficiente para desestimular a prática de infrações semelhantes pelos indiciados e por terceiros que estejam em posição similar à dos indiciados."

${ }^{177}$ Conforme YOUNGMAN, Ian. Directors' and Officers' Liability Insurance. $2^{\mathrm{a}}$ ed. Woodhead Publishing Limited: Cambridge, Inglaterra, 1999, p. 39. Vide também Priest, George L., Insurability and Punitive Damages, Paper 614, Faculty Scholarship Series, 1989. p. 1016. Disponível em $<$ http://digitalcommons.law.yale.edu/fss_papers/614>. Acesso em 15.10.2012.

${ }^{178}$ Nas palavras de James Roberts: "D\&O policies no longer invariably exclude all cover for fines and penalties. Even where there is some cover, however (eg, for regulatory fines), coverage is still subject to the overriding "insurable by law" requirement, whether expressed in the policy or not." ROBERTS, James. Can a $D \& O$ policy be used to cover directors' fines? Disponível em
} 
Vale mencionar, todavia, que um recente projeto de lei proposto nos Estados Unidos da América pelo deputado Barney Frank em 2012 ${ }^{179}$ sugere que seja proibida a contratação de seguro para cobertura de responsabilidades pessoais por penalidades, condenações judiciais ou penalidades pecuniárias impostas a instituições financeiras, companhias controladoras de instituições financeiras e entidades financeiras não-bancárias. O projeto ainda está em tramitação no congresso, mas já indica uma predisposição das autoridades de restringir a cobertura securitária para multas ao menos para determinadas instituições.

Em um levantamento realizado por uma corretora de seguros londrina ${ }^{180}$, as penalidades e multas regulatórias foram apontadas como uma das principais preocupações dos diretores, conselheiros, advogados internos e gerentes atuantes, em sua maioria, em companhias abertas inglesas. De acordo com o estudo, não há uma regra universal que vede ou permita o cobertura de multas e penalidades civis, havendo espaço para negociação deste tipo de cobertura.

Fundada neste entendimento, em 2012, a seguradora Lloyds Insurance lançou, no Reino Unido, uma cobertura especial para multas e penalidades, respeitados os limites impostos por lei, para indivíduos aos quais tenham sido imputadas as penalidades pecuniárias previstas no artigo 308 do Sarbanes Oxley Act de 2002, do Foreign Corrupt Practives Act, do UK Bribery Act de 2002 ou do Artigo 954 do Dodd-Frank Act ${ }^{181}$.

No Brasil, por não haver uma posição única quanto à possibilidade de se segurar multas e penalidades civis, por ora, apenas as seguradoras que tiveram suas apólices de seguro de responsabilidade civil aprovadas anteriormente ao mais recente posicionamento da SUSEP estão autorizadas a oferecer esta cobertura aos administradores.

$<$ http://clydeco.com/uploads/Files/BLG/legal_updates/Articles/Can\%20a\%20D\&O\%20policy\%20be\%20use d\%20to\%20cover\%20directors\%20fines.pdf>. Acesso em 15.10.2012.

${ }^{179}$ Vide H.R. 5860: Executive Compensation Clawback Full Enforcement Act. 112 ${ }^{\text {th }}$ Congress, $2011-2012$. Introduzida em 30 de maio de 2012. Texto integral e acompanhamento da tramitação disponíveis em $<$ http://www.govtrack.us/congress/bills/112/hr5860>. Acesso em 15.10.2012.

${ }^{180}$ Disponível em <http://www.willis.com/subsites/australia/documents/DO\%20review\%202012.pdf $>$. Acesso em 15.10.2012.

${ }^{181}$ Conforme <http://www.lloyds.com/news-and-insight/news-and-features/market-news/industry-news2012/new-global-liability-product-for-directors-and-officers $>$. Acesso em 15.10.2012. 


\subsubsection{MOMENTO DA NOTIFICAÇÃO: QUANDO E O QUE NOTIFICAR?}

Como descrito anteriormente, as apólices de seguro de responsabilidade civil de administradores são apólices à base de reclamação, podendo ou não estar condicionadas à notificação da reclamação pelo segurado. A maioria dos planos deste seguro não faculta ao segurado a apresentação da notificação, ficando o segurado obrigado a notificar a seguradora tão logo tome conhecimento de uma reclamação de terceiro.

Ainda assim, em função da heterogeneidade dos clausulados, é difícil advogar a favor da relevância do momento da notificação. Por não se tratar de risco de materialização imediata, a prontidão no envio de notificação no âmbito dos seguros à base de reclamações pode não parecer ser absolutamente imprescindível.

Contudo, é necessário frisar que, somente após ser cientificada dos sinistros ou potenciais sinistros por meio de notificação, a seguradora poderá tomar as medidas que julgar adequadas para conter ou remediar os efeitos daqueles. Por este motivo, as apólices de algumas seguradoras exigem que o segurado não só comunique uma reclamação de terceiro, como também a prática ou a tomada de conhecimento de qualquer ato, fato ou circunstância que possa desencadear uma reclamação de terceiro.

Diferentemente dos seguros de danos diretos, em que a prontidão na comunicação do sinistro à seguradora é determinante para a tomada das medidas cabíveis pela seguradora, seja no sentido de minorar o risco e conter as consequências do dano, seja para reparar o terceiro lesado, no seguro de danos indiretos, o momento da notificação nem sempre tem relevância para a seguradora.

De fato, em se tratando de apólice à base de reclamações, os efeitos práticos tanto dos atos ou fatos capazes de agravar o risco, quanto do momento em que o segurado efetivamente toma conhecimento da reclamação, não se produzem instantaneamente. Destarte, fica enfraquecida a argumentação de que a notificação tardia poderia dar ensejo à negativa de cobertura e à consequente inaplicabilidade do seguro. 
Em regra as apólices estabelecem um prazo máximo para que o segurado notifique a seguradora de uma ocorrência ou reclamação ou, alternativamente, preveem que a notificação deva ser apresentada "imediatamente" ou "tão logo possível”.

Para as apólices à base de ocorrência, na maioria dos estados norte-americanos, vigora a "regra da notificação-prejuízo" (notice prejudice rule), segundo qual a seguradora somente poderá negar cobertura em virtude de notificação intempestiva caso a seguradora consiga provar que o fato de ter sido notificada tardiamente causou um prejuízo.

Até pouco tempo atrás, a regra acima não era aplicada às apólices à base de reclamações, pois, conforme explicado em alguns julgados no estado do Texas, a demonstração de um prejuízo decorrente de uma notificação intempestiva descaracterizaria as apólices à base de reclamações e, ao se atribuir a ela a notice prejudice rule, estar-se-ia mudando sua natureza, que passaria a ser de uma apólice à base de ocorrências ${ }^{182}$.

Nos últimos anos, todavia, as regras atinentes às apólices à base de reclamações mudaram significativamente. Em 2009, a Suprema Corte do Texas ${ }^{183}$ determinou que quando uma notificação for apresentada durante a vigência da apólice, ainda que não sejam observados os parâmetros subjetivos (tais como "imediatamente", "tão logo possível" e "o quanto antes"), à seguradora incumbe demonstrar o prejuízo que sofreu para que possa negar cobertura.

Ainda no que tange à notificação, exceto pela reclamação propriamente dita, que deve ser comunicada sempre, não há um consenso entre as seguradoras quanto à comunicação de atos e fatos que possam ensejar a reclamação.

Nas entrevistas com as seguradoras ACE e CHUBB, foi proposta uma situação hipotética em que um diretor de uma companhia deixou de publicar as demonstrações financeiras da companhia no prazo regulamentar. Dadas as elevadas chances de instauração de um processo pela CVM, indagamos às seguradoras: (i) trata-se de uma hipótese de agravamento de risco?; e (ii) em caso afirmativo, poder-se-ia dizer que o

\footnotetext{
${ }^{182}$ Vide PAJ, Inc. v. Hanover Ins. Co., 243 S.W.3d 630, 631 (Tex. 2008).

${ }^{183}$ Vide Prodigy Commc'ns Corp. v. Agric. Excess \& Surplus Ins. Co., 288 S.W. 3d 374, 382-83 (Tex. 2009), reh'g withdrawn (Aug. 21, 2009); Fin. Indus. Corp. v. XL Specialty Ins. Co., 285 S.W.3d 877, 879 (Tex. 2009).
} 
estado anterior de risco foi alterado e, portanto, a seguradora deveria ter sido comunicada ${ }^{184}$ ?

De acordo com a seguradora $\mathrm{ACE}$, não se trata de agravamento de risco propriamente dito, pois, a despeito da probabilidade de ocorrência do sinistro, o risco não foi consideravelmente agravado e, portanto, não prejudica o equilíbrio contratual ${ }^{185}$. Ademais, como ainda não se materializou a reclamação do terceiro, é possível que ela não venha a se concretizar.

A seguradora ACE informou que orienta os segurados a comunicar a seguradora apenas quando da tomada de conhecimento formal de um ato ou fato passível de gerar sinistro (a apólice da seguradora, inclusive, apenas faculta, e não obriga o segurado a notifica-la de qualquer ato ou fato possível de agravar o risco, sendo inclusive expressa a referência ao documento que torne formal o conhecimento do ato ou fato $\left.{ }^{186}\right)$. No exemplo supra, pois, o administrador deveria comunicar a seguradora apenas quando fosse, de fato, autuado pela CVM.

A seguradora CHUBB, por sua vez, entende que tal situação seria interpretada como agravante do risco, estando o segurado obrigado a comunicar quaisquer atos ou fatos, independente do efetivo surgimento da reclamação do terceiro. Neste caso, portanto, a não publicação do fato relevante deveria ser comunicada imediatamente à seguradora,

\footnotetext{
${ }^{184}$ Conforme Art. 769/CC - O segurado é obrigado a comunicar ao segurador, logo que saiba, todo incidente suscetível de agravar consideravelmente o risco coberto, sob pena de perder o direito à garantia, se provar que silenciou de má-fé. Ensina TZIRULNIK, Ernesto et al.: "A comunicação é importante para habilitar o segurador, detentor da tecnologia de prevenção de riscos, para o exame do incidente e para emitir recomendações sobre medidas de prevenção que possam repristinar o estado anterior de risco. [...] Seu cumprimento (da comunicação) só é exigível quando o segurado tenha conhecimento do incidente ("logo que saiba") e do e do seu potencial agravante do risco ("se provar que silenciou de má-fé")". TZIRULNIK, Ernesto, CAVALCANTI, Flávio de Queiroz B.; e PIMENTEL, Ayrton. O contrato de seguro de acordo com o novo código civil brasileiro. $2^{\mathrm{a}}$ ed., São Paulo: Revista dos Tribunais, 2003, p. 83.

${ }^{185}$ “O incidente tem que ser potente para agravar consideravelmente o risco coberto. Não pode ser qualquer incidente, mas apenas aquele suscetível de provocar desequilíbrio contratual.” TZIRULNIK, Ernesto et al., op. cit., p. 73.

186،“Cláusula 2.3. - Durante o período de vigência desta apólice, é facultado ao Segurado notificar a Seguradora sobre a ocorrência de quaisquer atos, fatos ou circunstâncias que possam originar uma Reclamação. [...] A mera suspeita com relação uma possível Reclamação não implica na necessidade de Notificação à Seguradora, devendo o Segurado tão somente fazê-lo quando existir prova documental que fundamente tal expectativa. Cláusula 20.2 - O Tomador e o Segurado deverão, sob pena de perda do direito à indenização prevista nesta Apólice, comunicar, por escrito, à Seguradora, tão logo tome conhecimento sobre qualquer citação, carta ou documento recebido, que seja relacionado com qualquer Reclamação nos termos desta Apólice." Condições Gerais do Seguro de Responsabilidade Civil de Administradores ACE Seguradora. Disponível em <https://www.aon.com.br/profarma/docs/CG_RCG.pdf>. Acesso em 1.12.2012.
} 
sob pena de resultar em negativa de cobertura fundada na omissão de fato capaz de agravar o risco.

Ambas as seguradoras entrevistadas informaram que, embora nada impeça que o administrador, por garantia, comunique qualquer ato ou fato que julgue ter o condão de afetar o risco, muitos segurados evitam notificar atos que ainda não tenham gerado a uma reclamação temendo que, ainda que o sinistro não venha a se materializar, o valor do prêmio seja afetado quando da renovação da apólice.

Como se vê, portanto, o momento em que é feita a notificação pode afetar diretamente a aplicabilidade da cobertura securitária dependendo das circunstâncias em que é realizada e do clausulado da apólice.

\subsubsection{SOLIDARIEDADE}

Segundo a regra geral prevista na $\operatorname{LSA}^{187}$, os administradores responderão solidariamente por prejuízos decorrentes da não observância dos deveres legais que têm por objeto garantir o funcionamento regular da companhia, ainda que, pelo estatuto, tais deveres não incumbam a todos eles.

Esta regra não se aplica, no entanto, às companhias abertas em que, salvo algumas exceções, os administradores respondem somente pelo cumprimento dos deveres que lhes foram atribuídos pelo estatuto social ${ }^{188}$.

O cumprimento dos deveres objetivos dispostos no estatuto é de fácil aferição, diferentemente dos deveres amplos e gerais, que recebem tratamento especial distinto do princípio da incomunicabilidade da culpa consagrado na ordem jurídica. Neste diapasão, referido princípio vigora apenas no que tange às decisões de órgãos não-colegiados, sendo a responsabilidade solidária de membros de órgãos colegiados presumida. Sobre este tema, José Alexandre Tavares Guerreiro esclarece que:

\footnotetext{
${ }^{187}$ Art. 158, parágrafo $2^{\circ}$ - Os administradores são solidariamente responsáveis pelos prejuízos causados em virtude do não cumprimento dos deveres impostos por lei para assegurar o funcionamento normal da companhia, ainda que, pelo estatuto, tais deveres não caibam a todos eles.

${ }^{188}$ Art. 158, parágrafo $3^{\circ}$ - Nas companhias abertas, a responsabilidade de que trata o $\S 2^{\circ}$ ficará restrita, ressalvado o disposto no $\S 4^{\circ}$, aos administradores que, por disposição do estatuto, tenham atribuição específica de dar cumprimento àqueles deveres.
} 
Segundo este postulado fundamental [incomunicabilidade da culpa], cada administrador somente responderia por prejuízos decorrentes da sua própria culpa, não se lhe estendendo a imputabilidade pelos atos ilícitos praticados por outros administradores. [...] Considerando a estrutura administrativa da sociedade anônima, que toma como parâmetro básico a lei, mas se explicita concretamente no estatuto, pode-se afirmar que, nas deliberações ou decisões colegiais, existe, da parte de cada administrador, responsabilidade solidária presumida, que tanto deriva do dolo, quanto da culpa stricto sensu. [...] Na circunstância, porém, de o ato ilícito de outros administradores resultar ou for inerente a uma estrutura de gestão nãocolegiada, como ocorre na generalidade dos casos dos atos (ou omissões), inexiste a presumida culpa do administrador que não praticou diretamente o ato ou não se omitiu em matéria alheia às suas específicas atribuições funcionais $^{189}$.

Cabe salientar, contudo, que o fato de responsabilização dos administradores operar da forma aludida acima não significa que o sistema não comporte variações, conforme ensina Paulo F. C. Salles de Toledo:

Isto não impede, no entanto, que, incumbindo o dever descumprido a todos os diretores indistintamente, sejam todos eles responsabilizados. Nem obsta a que os conselheiros, manifestando validamente sua discordância, sejam pessoalmente eximidos da responsabilidade, que, de outro modo, atingiria coletivamente, a todos os componentes do conselho de administração ${ }^{190}$.

$\mathrm{Na}$ esfera securitária, são as partes contratantes que determinam como a solidariedade deve operar. Em regra, diante de uma negativa de cobertura fundada na alegação de declaração incorreta ou informação falsa, por exemplo, a redação da apólice determinará a extensão e a aplicabilidade da negativa aos segurados que eventualmente não participaram da contratação da apólice ou que não tinham conhecimento dos fatos supostamente inverídicos, incorretos ou inexatos que foram informados na contratação, permitindo que a cobertura permaneça em vigor para os "segurados inocentes".

A fim de evitar a afetação da cobertura dos administradores inocentes, a apólice deve conter dispositivos que tratem da individualização da cobertura e da inaplicabilidade da negativa quando de atos ou fatos que não possam ser atribuídos a estes administradores.

\footnotetext{
${ }^{189}$ GUERREIRO, José Alexandre Tavares, Responsabilidade dos Administradores de Sociedades Anônimas, in Revista de Direito Mercantil, Industrial, Econômico e Financeiro, ano XX (nova série), nº 42, São Paulo: RT, abril/junho 1981, pp. 85, 86 e 87.

${ }^{190}$ TOLEDO, Paulo Fernando Campos Salles de. O Conselho de Administração na Sociedade Anônima. Estrutura, Funções e Poderes, Responsabilidade dos Administradores. São Paulo: Atlas, 1997, pp. 74-75.
} 
Novamente aproveitando a experiência norte-americana, no caso Cutter\&Buck V. Genesis $^{191}$, em virtude de um escândalo contábil fez com que a companhia (Cutter\&Buck) precisasse retificar as demonstrações financeiras relativas aos quatro exercícios sociais anteriores, desencadeando diversas reclamações.

Na ocasião, a seguradora notificou Cutter\&Buck informando a rescisão da apólice por conta de declarações incorretas e informações falsas quando da emissão da apólice, incluindo as demonstrações financeiras ora retificadas. $\mathrm{O}$ tribunal considerou que o diretor presidente da Cutter\&Buck, signatário da apólice, tinha conhecimento das declarações falsas e permitiu a rescisão da apólice extensível a todos os demais segurados ${ }^{192}$.

No caso In re HealthSouth Corp. ${ }^{193}$, o desfecho foi diferente. O foro distrital do Alabama, com base em uma apólice cuja redação era explícita quanto à individualização da cobertura em relação aos segurados, decidiu de maneira diversa. No caso, certos administradores e empregados foram considerados responsáveis por fraudes alegadas pela Securities Exchange Commision, pois diversos outros processos de fraude contra a companhia e seus administradores também estavam em curso.

A seguradora da HealthSouth propôs uma ação buscando a rescisão das apólices ou, alternativamente, a possibilidade de negar cobertura. Contrariamente ao caso Cutter\&Buck, a apólice continha cláusula expressa de incomunicabilidade, dificultando a imputação da fraude (e consequente elisão do dever de indenizar) aos demais administradores beneficiários da apólice. Confira-se:

\footnotetext{
${ }^{191}$ Cutter \& Buck, Inc. v. Genesis Ins. Co., 306 F. Supp. 2d 988, 997 (W.D. Wash. 2004), aff'd, 144 Fed. Appx. 600 (9th Cir. 2005).

${ }^{192}$ Neste caso, a apólice continha os seguintes dizeres: "In the event that the Application, including materials submitted therewith, contains misrepresentations made with the actual intent to deceive, or contains misrepresentations which materially affect either the acceptance of the risk or the hazard assumed by the Insurer under this Policy, this Policy in its entirety shall be void and of no effect whatsoever; and provided, however, that no knowledge possessed by any director or officer shall be imputed to any other director or officer except for material information known to the person or persons who signed the Application." A cláusula foi interpretada pelo tribunal como tendo abrangido todos os administradores da companhia. In Cutter \& Buck, Inc. v. Genesis Ins. Co., 306 F. Supp. 2d 988, 997 (W.D. Wash. 2004), aff'd, 144 Fed. Appx. 600 (9th Cir. 2005). Baseado em um dispositivo semelhante, um tribunal da Califórnia permitiu a rescisão total de uma apólice de seguro de responsabilidade civil de administradores. In Fed. Ins. Co. v. Homestore, Inc., 144 Fed. Appx. 641, 648 (9th Cir. 2005); TIG Ins. Co. of Mich. v. Homestore, Inc., 40 Cal.Rptr. 3d 528, 533 (Cal. Ct. App. 2006).

${ }^{193}$ HealthSouth, 308 F. Supp. 2d at 1261.
} 
Tal(is) proposta(s) escrita(s) deve(m) ser interpretada(s) como uma proposta [de seguro] independente para cada um dos Segurados. No que diz respeito às declarações e afirmações contidas em tal(is) proposta(s) [de seguro], nenhuma das afirmações da proposta ou informação detida por qualquer Segurado poderá ser imputada a qualquer outro Segurado para fins de determinação do cabimento ou não de cobertura $^{194}$. (tradução livre)

O foro entendeu que a cláusula acima impedia a rescisão extensiva a todos os segurados, a menos que a seguradora conseguisse obter prova de que cada um dos segurados abrangidos pela apólice tinha conhecimento da declaração falsa contida na proposta.

Estes exemplos ilustram, outrossim, mais uma situação que corriqueiramente afeta a aplicabilidade do seguro de responsabilidade de administradores, pois, dependendo da forma como a apólice é redigida, a aplicabilidade do seguro com relação a um determinado segurado pode afetar a cobertura securitária dos demais segurados.

\subsubsection{RECLAMAÇÕES ENVOLVENDO DISPUTAS ENTRE SEGURADOS,} ENTRE SEGURADO E COMPANHIA E ENTRE SEGURADO E ACIONISTA

Dada a complexidade das atividades que desenvolvem, a gestão das companhias modernas, sobretudo as de grande porte, requer a implementação de sofisticadas estruturas de administração. Em busca de eficiência, não raro são conferidos amplos poderes a diversos indivíduos dentro da companhia (ainda que não ocupem cargos de gestão).

Por este motivo, a maior parte das apólices de seguro de responsabilidade civil de administradores inclui, na definição de segurado, não só os administradores (que, como mencionado anteriormente, compreendem também diretores e membros do conselho de administração), como também procuradores e empregados do tomador (i) que exerçam funções gerenciais ou mantenham posição executiva equivalente; e (ii) que não sejam

\footnotetext{
${ }^{194}$ No original: "Such written application(s) for coverage shall be construed as a separate application for coverage by each of the Insured Persons. With respect to the declarations and statements contained in such application(s) for coverage, no statement in the application or knowledge possessed by any Insured Person shall be imputed to any other Insured Person for the purpose of determining if coverage is available." In In re HealthSouth Corp. Ins. Litig., 308 F. Supp. 2d 1253 (N.D. Ala. 2004).
} 
administradores, mas exerçam funções em nome do tomador (e.g., advogado empregado pelo tomador no exercício da advocacia em nome do tomador).

A constante interação entre as diversas categorias de indivíduos abrangidos pela apólice muitas vezes suscita desentendimentos. Assim, é possível que dois ou mais segurados a serviço de uma mesma companhia apresentem posicionamentos antagônicos com relação a uma determinada questão, originando uma disputa passível de gerar prejuízos indenizáveis nos termos do seguro de responsabilidade estudado.

Para evitar que um segurado promova uma ação contra outro segurado (e, em seguida, o segurado que ocupa o polo passivo busque indenização do seguro), as apólices costumam conter previsão expressa eximindo a seguradora da obrigação de indenizar o segurado nestas ocasiões, sendo conhecida como exclusão segurado versus segurado.

O intuito deste dispositivo é evitar a atuação de segurados que, mancomunados com a companhia, planejem ou simulem uma disputa que permitiria à companhia repor perdas decorrentes do curso normal das atividades por meio de reclamações contra os segurados envolvidos que deram causa às perdas ${ }^{195}$. Adolfo Paolini et al. corroboram este entendimento e reforçam que esta cláusula se destina a evitar ainda que a seguradora acabe por financiar litígios internos das companhias ${ }^{196}$.

Igualmente problemáticas são as reclamações dos acionistas contra segurados e da própria companhia (geralmente tomadora do seguro) contra o segurado. Nos Estados Unidos da América, estas exclusões são pouco comuns (vide Seção 6.1.2), enquanto no Brasil, as reclamações feitas pelo acionista costumam ser excluídas do âmbito de cobertura (exceto nos casos de ações sociais e em casos específicos mediante contratação de extensão de cobertura).

\footnotetext{
195، The 'insured v. insured' exclusion prohibits one insured from suing another insured. The primary purpose is to exclude coverage for collusive or "friendly" suits in which a company may seek to recover ordinary business losses by making claims against the D\&O Insureds, who were involved in the transaction that gave rise to the losses." BITTLE, Lyndon F., SUTHERLAND, J. Michael, BARNHOUSE, Shelbi, POCSIK, Stephen, op. cit., p. 203.

196،"In D\&O insurance, [the insured vs insured exclusion] has two primary aims: (1) to avoid the insurer having to finance internal litigation within a company; and (2) to prevent a company with entity cover in place from recovering at the expense of the insurer as a remedy for loss caused by erroneous management decisions." PAOLINI, Adolfo; NAMBISAN, Deepak, op. cit., p. 72.
} 
Costuma haver ainda uma vedação expressa ao acionista que também se enquadre, por suas funções, no conceito de segurado, impedindo-o de demandar contra outro administrador também segurado.

Apesar de o Brasil estar caminhando para o sistema de controle difuso e de capital disperso, ainda existem diversas companhias em que o poder decisório concentra-se nas mãos do acionista controlador (inclusive quando o acionista figura também como administrador), motivo pelo qual as seguradoras têm por hábito inserir esta limitação no clausulado da apólice. Mais uma vez, cabe observar que a existência de tais mecanismos provavelmente se justifica pelo contexto de controle acionário predominante no Brasil (vide seção 6.1.2).

Como se nota, o mercado securitário dispõe de mecanismos não só para evitar fraudes do segurado, mas também para afastar tentativas de burla que possam emanar da própria companhia e/ou de seus acionistas. Estes mecanismos evitam procuram evitar que acionistas e segurados, agindo em conluio, utilizem o seguro como instrumento para auferir benefícios próprios ou à companhia.

\subsubsection{OUTRAS LIMITAÇÕES}

Algumas limitações não dizem respeito necessariamente ao comportamento do segurado, mas sim a questões relativas à própria operacionalização da apólice.

Como visto, as apólices são contratadas pelas companhias e abrangem um grupo amplo de segurados, ou seja, como não se atribui um valor fixo ao risco segurado (pois o risco, além de recair sobre todo o patrimônio do segurado, tem latência prolongada), o grupo de segurados fica sujeito ao limite máximo da garantia. Significa dizer que o valor máximo previsto na apólice a ser pago a título de indenização não se aplica a cada segurado individualmente, mas ao conjunto de segurados.

Desta feita, na hipótese de reclamações concomitantes cujos custos de defesa ou eventuais condenações ocorram durante um mesmo período, os beneficiários terão que compartilhar o limite máximo da garantia. Neste caso, os segurados ficarão sujeitos ao esgotamento da quantia máxima da indenização a ser paga pela seguradora. 
A ordem de pagamento dos segurados é outro ponto de atenção relativo à operacionalização da apólice. Partindo desta mesma hipótese em que mais de um segurado é reclamado concomitantemente e os valores a serem pagos superam o limite máximo da apólice, não se pode assegurar qual deles receberá a indenização primeiro. Segundo informações prestadas pelas seguradoras ACE e ZURICH, não há um critério fixo que determine qual deles irá receber seu quinhão primeiro.

Em um exemplo hipotético, se a apólice previr um limite de indenização no valor de 200 destinado ao ressarcimento de sinistros e dois segurados forem demandados simultaneamente nos valores de 180 e 130 cada, dependendo das circunstâncias, é possível que um deles deixe de receber o valor integral de sua parcela de indenização.

Certamente este é um exemplo demasiadamente simplista que não leva em conta outras variantes que também afetam a ordem de pagamento dos beneficiários, tais como os diferentes momentos em que os segurados incorrem em custos de defesa iniciais, eventuais novas reclamações de outros segurados que venham a surgir no mesmo período, dentro outros fatores que também podem interferir na ordem do pagamento dos segurados. Ainda assim, esta não deixa de ser uma importante limitação à aplicabilidade do seguro, pois o administrador pode restar descoberto por conta do compartilhamento do valor da indenização.

\subsubsection{AFASTAMENTO DA APLICABILIDADE DO SEGURO}

As hipóteses de afastamento da aplicabilidade do seguro são previstas na apólice na cláusula de exclusões de cobertura e, portanto, podem variar consideravelmente dependendo dos termos acordados entre segurado e seguradora. Além das exclusões avençadas caso a caso, também são motivo de inaplicabilidade do seguro as hipóteses em que o segurado, por ter atuado fora do âmbito de seus deveres e obrigações (seja sob a perspectiva societária, seja pela perspectiva securitária), deixa de ter direito a indenização. 


\subsubsection{EXCLUSÕES DE COBERTURA}

Como mencionado, as exclusões de cobertura são estabelecidas caso a caso e, exceto pela prática de ato doloso, podem passar a integrar o conceito de risco coberto mediante contratação de extensão de cobertura.

As exclusões de cobertura mais comuns compreendem:

(i) atos dolosos do segurado que, em regra, incluem: (a) enriquecimento ilícito do segurado por uso indevido de informações privilegiadas na realização negócios ou transações comerciais; (b) atos ilícitos dolosos em geral; e (c) prática de ato ou omissão tipificada criminalmente.

Para que as exclusões deste item (i) sejam aplicáveis, é necessária sentença transitada em julgado em que fique comprovado o dolo do segurado. Havendo sentença condenatória neste sentido, o segurado deverá ressarcir a seguradora dos custos de defesa que tiverem sido adiantados.

(ii) reclamações anteriores à data limite de retroatividade especificada na apólice ou reclamações que se baseiem em um determinado ato ou fato danoso que já tenha sido objeto de uma reclamação feita contra os segurados anteriormente à data limite de retroatividade;

(iii) reclamações decorrentes de danos ambientais (bem como danos morais, danos corporais, danos à propriedade e danos relacionados a reclamações por práticas trabalhistas indevidas; e

(iv) reclamações no interesse de ou apresentadas pela companhia ou por diretor, salvo nos casos de ação movida por acionista da companhia que seja apresentada ou mantida em benefício e por conta da companhia, sem a solicitação, assistência ou participação de qualquer segurado. 


\subsubsection{PERDA DO DIREITO À INDENIZAÇÃO E RESCISÃO}

Como as hipóteses de quebra de deveres e obrigações do segurado variam de acordo com o tipo de seguro e o grau de risco envolvido (vide seção 5.5.2), as hipóteses de perda de direito à indenização e rescisão do contrato também são estabelecidas caso a caso, exceto por aquelas que decorrem de lei.

Abaixo estão enumeradas algumas das hipóteses de perda de direito e rescisão mais frequentes nas apólices de seguro de responsabilidade civil dos administradores ${ }^{197}$. Implicam a perda de direito à indenização e/ou rescisão do contrato de seguro:

(i) as hipóteses em que o segurado fizer, intencionalmente e de má-fé, declarações falsas, incompletas ou omitir circunstâncias de seu conhecimento que pudessem ter influído na aceitação da proposta, na extensão da cobertura ou na fixação do prêmio;

(ii) as hipóteses em que o segurado deixar de cumprir as obrigações convencionadas na apólice;

(iii) as hipóteses em que o segurado se recusar a fornecer qualquer documentação que seja exigida e indispensável à comprovação da reclamação apresentada ou à mensuração dos prejuízos;

(iv) a verificação, na ocorrência ou não de um sinistro, de que as informações prestadas pelo tomador, pelo segurado ou pelo corretor não correspondem à realidade e interferiram na avaliação e agravamento do risco objeto da apólice (se de forma não intencional, a seguradora poderá cobrar a respectiva diferença de prêmio referente ao aumento do risco ou resolver o contrato);

(v) o reconhecimento, pelo segurado, de sua responsabilidade ou a realização de transação com o terceiro prejudicado, sem prévia e expressa anuência da seguradora.

\footnotetext{
${ }^{197}$ Conforme amostragem de apólices das seguradoras ACE, ZURICH e Liberty Seguros S.A.
} 


\subsubsection{O EXEMPLO DO BANCO SANTOS S.A.}

Conquanto as instituições financeiras não sejam objeto de análise deste trabalho, há um recente exemplo emblemático de negativa de cobertura de discutida em juízo no Brasil que merece análise.

Trata-se de recurso de apelação interposto contra sentença que julgou improcedente ação de cobrança ajuizada por Procid Participações e Negócios S.A. ("Procid”) e Edmar Cid Ferreira (“ECF”) contra o Unibanco AIG Seguros e Previdência (“AIG”).

A ação voltava-se a obrigar a AIG a arcar, nos termos de uma apólice de seguro de responsabilidade civil, com os valores despendidos pelos autores relativos aos procedimentos administrativos decorrentes da intervenção do Banco Central do Brasil no Banco Santos S.A., bem como às ações judiciais, cíveis ou penais inseridas neste contexto.

O pagamento que se pretendia da AIG estaria amparado por apólice de seguro destinada à cobertura de responsabilidades civis imputadas aos gestores de sociedades integrantes do conglomerado econômico controlado pela Procid. Em termos objetivos, a ação proposta destinava-se a obter a condenação da AIG a custear despesas com a defesa de ECF em procedimentos administrativos e judiciais relacionados à decretação da liquidação extrajudicial da instituição financeira controlada pela Procid, qual seja o Banco Santos S.A., ora submetido a processo de falência.

Em atendimento ao disposto na lei, previamente à conclusão do contrato de seguro, Procid e ECF forneceram à AIG as informações indispensáveis à avaliação do risco envolvido na operação, declarando expressamente que (a) não previam significativa redução nos seus lucros ou reformulação dos seus relatórios financeiros; (b) realizaram as necessárias diligências, desconhecendo qualquer circunstância ou incidente que pudesse dar origem a uma reclamação passível de cobertura pelo seguro; e (c) se as informações contidas na proposta sofressem mudança até a data efetiva do seguro, a seguradora seria comunicada.

Como restou provado nos autos, à época da proposta, as demonstrações financeiras já deixavam transparecer a situação econômica do banco que, pouco depois da celebração 
do contrato, levaria a referida instituição financeira à liquidação extrajudicial e falência. Ainda, o processo de deterioração econômico-financeira não representou ocorrência superveniente à celebração do contrato de seguro.

Por estes motivos, AIG negou-se a indenizar os segurados e teve a negativa de cobertura confirmada por sentença judicial, com base no fundamento de que o contrato de seguro:

(i) foi celebrado mediante dolo da Procid, com o fim de obter cobertura para eventos já ocorridos, o que torna o instrumento nulo de pleno direito;

(ii) resultou de manifesta má-fé dos segurados, consubstanciada em comportamentos irregulares (hoje notórios) de responsabilidade dos dirigentes do Banco Santos S.A., causadores da quebra da instituição, maliciosamente falseados no momento da contratação do seguro;

(iii) embasou-se em proposta que continha declarações inexatas e que omitia circunstâncias capazes de influir na sua aceitação ou no valor do prêmio, fato que retira dos segurados o direito à indenização securitária; e

(iv) teve sua execução eivada de má-fé, traduzida na concentração desproporcional e inexplicável da cobertura pretendida por um só dirigente, apta a desvirtuar o objeto e a esvaziar por completo a finalidade social do contrato.

Confira-se o acórdão do Tribunal de Justiça de São Paulo:

ILEGITIMIDADE ATIVA. INOCORRÊNCIA AÇÃO DE COBRANÇA DE SEGURO DE RESPONSABILIDẢDE DOS ADMINISTRADORES DE SOCIEDADES COMERCIAIS ("D\&O INSURANCE") PESSOA IURÍDICA LEGITIMADA A PARTIR DE ENDOSSO DA APÓLICE DE SEGURO ADMISSIBILIDADE PESSOA FÍSICA, POR OUTRO LADO, QUE ERA ADMINISTRADORA DA SOCIEDADE SEGURADA LEGITIMIDADE ADVINDA DA PRÓPRIA NATUREZA DO SEGURO PRELIMINAR AFASTADA.

PRESCRIÇÃO. INOCORRÊNCIA AÇÃO DE COBRANÇA DE SEGURO DE RESPONSABILIDADE DOS ADMINISTRADORES DE SOCIEDADES COMERCIAIS ("D\&O INSURANCE") AUTORES 
QUE CUIDARAM DE AJUIZAR AÇÃO CAUTELAR INTERRUPTIVA DE PROTESTO REINICIO DA CONTAGEM DO PRAZO DEMORA, ADEMAIS. DECORRENTE DE EXIGÊNCIAS DA PRÓPRIA SEGURADORA TERMO INICIAL TOMADO A PARTIR DA EFETIVA NEGATIVA DE PAGAMENTO PRELIMINAR AFASTADA.

SEGURO. AÇÃO DE COBRANÇA DE SEGURO DE RESPONSABILIDADE DOS ADMINISTRADORES DE SOCIEDADES COMERCIAIS ("D\&O INSURANCE") PROCESSOS ADMINISTRATIVOS QUE DÃO CONTA DA INFRAÇÃO, PELO ADMINISTRADOR, AOS DEVERES DE CUIDADO E LEALDADE ('DUTIES OF CARE AND LOYALTY') APURAÇÃO DA PRÁTICA DE ATOS FRAUDULENTOS ANTERIOR À CONTRATAÇÃO E QUE NÃO FORAM INFORMADOS $\grave{A}$ SEGURADORA ("KNOWN ACTIONS") EXCLUDENTES ABSOLUTOS DE RESPONSABILIDADE PRECEDENTES DOUTRINÁRIOS ESTRANGEIROS RECURSO IMPROVIDO.

SEGURO. AÇÃO DE COBRANÇA DE SEGURO DE RESPONSABILIDADE DOS ADMINISTRADORES DE SOCIEDADES COMERCIAIS ("D\&O INSURANCE") PRETENDIDO ADIANTAMENTO DOS CUSTOS PARA A DEFESA JUDICIAL DO ADMINISTRADOR.

PODER JUDICIÁRIO. TRIBUNAL DE JUSTIÇA DO ESTADO DE SÃO PAULO INADMISSIBILIDADE NEGATIVA DA SEGURADORA BASEADA NAS EXCLUDENTES DE "KNOWN ACTIONS" E "DELIBERATE ACTS" ADMISSIBILIDADE ATOS DELIBERADAMENTE FRAUDULENTOS PRATICADOS E APURADOS ANTERIORMENTE À CONTRATAÇÃO DO SEGURO RECONHECIMENTO JUDICIAL COMPROMISSO DE REEMBOLSO. .ADEMAIS, QUE NÃO ESTÁ PREVISTO EM CONTRATO E NÃO PODE SER ADMITIDO RECURSO IMPROVIDO.

HONORÁRIOS ADVOCATÍCIOS. FIXAÇÃO DETERMINADA COM BASE NO VALOR DA CAUSA ADMISSIBILIDADE AUSÊNCIA DE ALEGAÇÃO ESPECÍFICA PELAS PARTES INTERESSADAS RECURSO IMPROVIDO VOTO VENCIDO. (TJSP

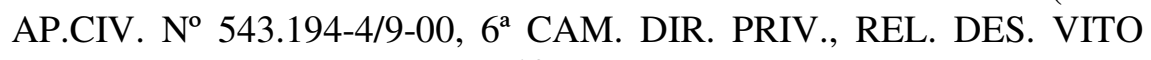
GUGLIELMI, J. 11/12/2008) (grifou-se).

Este processo ilustra, pois, um caso típico de afastamento da aplicabilidade do seguro de responsabilidade civil de administradores relacionado à conduta do administrador.

\subsection{ADMISSIBILIDADE DO SEGURO DE RESPONSABILIDADE CIVIL DE ADMINISTRADORES}

Considerados os aspectos atinentes à aplicabilidade do seguro de responsabilidade civil, coloca-se o debate da admissibilidade do seguro de responsabilidade civil de 
administradores. Desde sua concepção, muito se discute acerca da possibilidade de a responsabilidade pessoal ser objeto de seguro.

Picard e Besson asseveram que o Código Francês, ao vedar o seguro sobre atos dolosos, a contrariu sensu, expressa a validade dos seguros sobre atos ou fatos não intencionais. Segundo os autores, todos os sinistros causados pelo segurado que decorram de simples imprudência ou negligência são passíveis de serem cobertos por seguro ${ }^{198}$.

Esta questão foi objeto de intensa discussão no Brasil à época da vigência do Código Civil de 1916, cujo artigo 1.436 tratava como nulo o contrato de seguro quando o risco se filiasse a atos ilícitos do segurado, sem entrar no mérito da culpabilidade ${ }^{199}$. Se o CC/02 tivesse intentado afastar também os atos decorrentes de culpa do segurado, em seu artigo 762, em vez de ato doloso, teria proibido que atos ilícitos de um modo geral fossem passíveis de operações de seguro ${ }^{200}$.

Ao defender a admissibilidade do seguro de responsabilidade, Pedro Alvim explica:

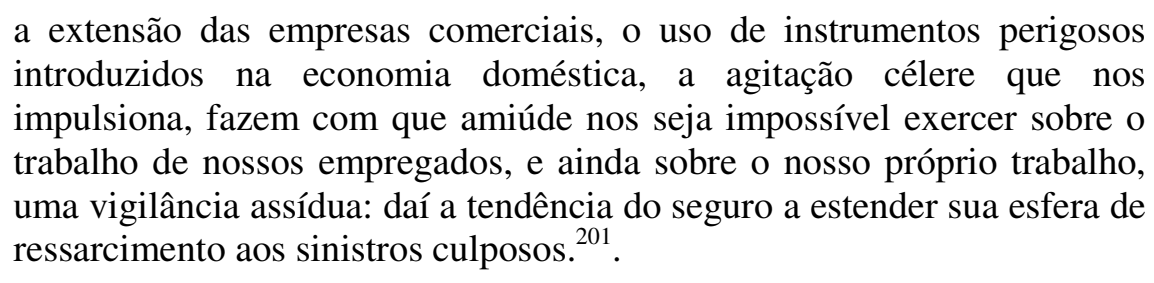

A natureza da atividade empresária é, portanto, um primeiro elemento que justifica a adoção do seguro de responsabilidade de administradores.

\footnotetext{
${ }^{198}$ Conforme PICARD, M. e BESSON, A., op. cit., p. 116.

${ }^{199}$ Sobre esta discussão, vide DIAS, José Aguiar. Da responsabilidade Civil, Vol. II, Rio de Janeiro: Forense, 1997 , p. $1125-1126$.

${ }^{200}$ Confira-se nas palavras de José Aguiar Dias: “O Código Civil de 2002, atento às discussões doutrinárias e jurisprudenciais que se travaram na vigência do código anterior, encerrou o assunto não mais se referindo a atos ilícitos, preferindo a objetividade da solução de dizer que nulo será o contrato para a garantia de risco proveniente de ato doloso do segurado, do beneficiário, ou de representante de um ou de outro.” DIAS, José Aguiar, op. cit., p. 1129.

${ }^{201}$ ALVIM, Pedro. Responsabilidade Civil e Seguro Obrigatório. São Paulo: Revista dos Tribunais, 1972.
} 


\subsubsection{FUNÇÃO SOCIAL}

Conquanto não seja objeto de discussão a função social dos contratos de seguro, não se pode passar ao largo das diversas finalidades a que se presta a seguro de responsabilidade.

A este respeito, vale conferir a lição de Humberto Theodoro Júnior sobre a determinação da função social. O autor constata que a lei prevê apenas uma cláusula geral, sem, contudo, predeterminar os meios para verificação do atendimento aos fins econômicos e sociais a que se destina um determinado instituto ou contrato. Neste sentido, cumpre ao sistema jurídico avaliar se tais fins estão devidamente inseridos nas relações jurídicas privadas e zelar por sua contínua observância nas relações entre particulares ${ }^{202}$.

Partindo-se desta premissa, a melhor doutrina defende não só a licitude do seguro de responsabilidade civil, como enaltece sua função social e o atendimento aos princípios consagrados no $\mathrm{CC} / 02^{203}$ :

Nenhuma ofensa à moral ou aos bons costumes pode encerrar o seguro de responsabilidade civil, salvo a restrição quanto ao dolo do segurado. Pelo contrário, ele até vem trazer importante contribuição no sentido de garantir, melhor do que acontecia antes de sua utilização, o ressarcimento do dano, atendendo, do mesmo passo, a uma das maiores preocupações dos juristas quanto à forma de proporcionar a reparação, sem, contudo, alterar exageradamente o equilíbrio, que a satisfação do dano, no empenho de o restabelecer, só encarando o interesse de uma parte, acabava rompendo em relação ao interesse oposto ${ }^{204}$.

Neste mesmo sentido, Ernesto Tzirulnik esclarece:

[...] sobretudo no ramo de Responsabilidade Civil, o interesse segurado passa a ser considerado como implicando tanto o risco de diminuição do patrimônio do segurado quanto - e, igualmente - o risco de permanência do estado de dano no patrimônio do lesado. [...] É fundamental que se tenha em conta, nesse intuito, que a preservação do patrimônio do

\footnotetext{
202، Convém registrar que a lei prevê a função social do contrato, mas não a disciplina sistemática ou especificamente. Cabe à doutrina e à jurisprudência pesquisar sua presença difusa dentro do ordenamento jurídico e, sobretudo, dentro dos princípios informativos da ordem econômica e social traçada pela constituição". THEODORO JÚNIOR, Humberto. O contrato e sua função social. $2^{\mathrm{a}}$ ed. Rio de Janeiro: Forense, 2004, p. 95.

${ }^{203}$ Art. 2.035, parágrafo único - Nenhuma convenção prevalecerá se contrariar preceitos de ordem pública, tais como os estabelecidos por este Código para assegurar a função social da propriedade e dos contratos.

${ }^{204}$ DIAS, José Aguiar, op. cit., p. 1128.
} 
segurado não visa tão-somente aos seus interesses, mas, em última análise, é ela que vai garantir a indenização justa dos danos sofridos pela vítima, permitindo que essa reparação ultrapasse os limites econômicos, muitas vezes estreitos, do patrimônio do causador do dano, e até mesmo, da indenização das vítimas, para beneficiar todo o conjunto social ${ }^{205}$.

Em linha com o entendimento de que o seguro beneficia não só o próprio segurado, como também o terceiro que por este vier a ser lesado, o substitutivo ao Projeto de Lei n 3.555 de 2004, de autoria do deputado José Eduardo Cardozo, que estabelece normas gerais em contratos de seguro privado e que revoga dispositivos do $\mathrm{CC} / 02$, do Código Comercial Brasileiro e do Decreto-Lei ${ }^{\circ} 73$ de 1966, torna expressa a tutela ao interesse dos terceiros:

\begin{abstract}
Art. 104. O seguro de responsabilidade civil garante o interesse do segurado contra os efeitos da imputação de responsabilidade e do seu reconhecimento, e dos terceiros prejudicados.

Art. 105. São credores da garantia o segurado e os prejudicados.

$\S 1^{\circ}$ Os prejudicados são os únicos credores da indenização devida pela seguradora, salvo o disposto no $\S 3^{\circ}$ deste artigo, e poderão exercer seu direito de ação contra esta, respeitado o limite garantido pelo contrato, com a faculdade de citar o responsável como litisconsorte.
\end{abstract}

Evidencia-se assim que o seguro de responsabilidade civil cumpre uma função social, atendendo aos anseios não só do segurado, mas também de terceiros de um modo geral. Especificamente no caso do seguro de responsabilidade civil de administradores, por exemplo, ele atende ao segurado, aos investidores, ao mercado de capitais e ao Estado como um todo.

\title{
6.3.2. O PAPEL DO SEGURO NA GOVERNANÇA CORPORATIVA
}

Diversos estudos realizados na última década examinam a hipótese de o seguro de responsabilidade civil de administradores ser um indicativo da qualidade da governança corporativa das companhias.

Baker e Griffith verificaram que a subscrição do risco no caso do seguro sob análise leva em conta dois pilares principais: (i) a análise da saude financeira, visando aferir a

\footnotetext{
${ }^{205}$ TZIRULNIK, Ernesto. O Futuro do Seguro de responsabilidade Civil, in Doutrinas Essenciais Responsabilidade Civil: Direito das Obrigações e Direito Negocial (org. Nelson Nery Junior e Rosa Maria de Andrade Nery), 2a ed., São Paulo: Revista dos Tribunais, 2010, p. 721 e 724.
} 
possibilidade de uma perda significativa; e (ii) a avaliação da governança corporativa, pois a probabilidade de uma perda está ligada à infração à lei do mercado de capitais ou outras violações no âmbito societário. Na medida em que o prêmio reflete a avaliação que a seguradora faz dos níveis de governança (sendo mais elevado para as companhias com práticas de governança menos satisfatórias), ele pode ser um indicador da qualidade da governança das companhias ${ }^{206}$.

As agências de classificação de risco, ao avaliarem o risco, também examinam a governança corporativa. Contudo, como observam Baker e Griffith, estas agências são prestadoras de serviço e são remuneradas como tal, não sofrendo qualquer prejuízo caso realizem uma classificação imprecisa ou incorreta.

As seguradoras, por sua vez, ao subscreverem determinado risco, colocam em jogo seu próprio capital, de modo que uma avaliação de risco equivocada pode acarretar perdas substanciais. Logo, as seguradoras possuem um incentivo extra para realizar uma criteriosa análise das práticas de governança corporativas das companhias seguradas ${ }^{207}$.

Ademais, a qualidade e o tipo de informação a que as seguradoras têm acesso vão além das informações que as companhias são regularmente obrigadas a publicar, a começar pelo questionário que os segurados devem responder na contratação inicial do seguro. Estes questionários possuem diversas indicativos de práticas de governança adotadas pela tomadora.

Em uma segunda etapa, as seguradoras entrevistam os administradores, realizando uma criteriosa avaliação da estrutura administrativa e dos planos de gestão de curto, médio e longo prazo. Nestas entrevistas, são abordados tópicos como as políticas internas para determinação de incentivos aos executivos, os métodos de cálculo da remuneração dos executivos, a robustez dos controles internos e a cultura de compliance da companhia ${ }^{208}$.

Tendo em vista que as seguradoras podem se comprometer a manter todas as informações em caráter confidencial, elas acabam tendo acesso a informações sigilosas e,

\footnotetext{
${ }^{206}$ BAKER, Tom; GRIFFITH, Sean J., Predicting Corporate Governance Risk: Evidence from the Directors' and Officers' Liability Insurance Market. Chicago Law Review, v. 74, 2007, pp. 516 e 536.

${ }^{207}$ BAKER, Tom; GRIFFITH, Sean J., op. cit., p. 515.

${ }^{208}$ Conforme KANG, Christine, op. cit., p. 18.
} 
de posso de tais informações, podem basear a precificação do seguro em informações privadas que ainda não estão refletidas no preço das ações da companhia. Portanto, é possível que o processo de subscrição do risco deste seguro tenha êxito no exame criterioso dos assuntos relativos à governança convencional e "aprofundada" e, com isso, incorpore estas informações no prêmio ${ }^{209}$.

Nos Estados Unidos da América, não há muitos estudos empíricos do seguro de responsabilidade de administradores, principalmente porque as informações a este respeito não são públicas. Já no Canadá, as informações básicas relacionadas ao seguro (limite da apólice, prêmio e franquia) devem constar das demonstrações financeiras por força da regulamentação local ${ }^{210}$, permitindo a análise de amostragens de companhias contratantes do seguro naquele país.

Em 1997, John E. Core realizou um estudo empírico com 222 companhias canadenses (com exercício fiscal encerrado em 1994), constatando que a sujeição ao risco de litígio e o custo do financiamento das dificuldades financeiras eram os grande impulsionadores da contratação do seguro de responsabilidade civil de administradores ${ }^{211}$.

Em 2000, o mesmo autor verificou que as diversas formas de governança corporativa adotadas pelas companhias são estatisticamente determinantes para o estabelecimento do prêmio: quanto menos eficientes as políticas de governança, mais elevados os prêmios. John E. Core concluiu, pois, que as informações embutidas no prêmio deste seguro são um importante termômetro da qualidade de governança corporativa ${ }^{212}$.

\footnotetext{
${ }^{209}$ Nas palavras de Christine Kang: "Because underwriters can commit to confidentiality, they can base their pricing on non-public information not already reflected in a company's share price. Essentially, it is possible that the D\&O underwriting process successfully delves into both conventional and deep governancell issues and incorporates this information into the premium." KANG, Christine, op. cit., pp. 18-19.

${ }^{210}$ Conforme KANG, Christine, op. cit., p. 39.

${ }^{211}$ CORE, John E, On the Corporate Demand for Directors' and Officers' Insurance, The Journal of Risk and Insurance, v.64, No. 1, 1997, pp. 63-87.

${ }^{212}$ Conforme CORE, John E., op. cit.
} 
Em um estudo com uma amostragem de companhias também canadenses, Christine Kang, assim como John E. Core, constatou uma oscilação no prêmio relacionada a variáveis que atestam a qualidade da governança corporativa ${ }^{213}$.

Endossando a teoria de Baker e Griffth, Christine Kang explica que a governança corporativa é um importante componente da equação de precificação realizada pela seguradora, uma vez que, sem este componente, as seguradoras não conseguiriam estabelecer as diferenças entre companhias com atividades empresariais com características idênticas ${ }^{214}$.

Christine Kang examina também se eventualmente as companhias não gerenciam os custos de seguro eliminando as características da governança que geralmente levam a prêmios mais elevados. Constata que, embora fosse possível que os administradores, manipulando o sistema, apenas "simulassem a adoção de boas práticas" (por exemplo, reduzindo o valor da remuneração dos executivos), os dados empíricos coletados demonstraram que os administradores não têm por hábito atuar desta forma e que as companhias não gerenciam os custos do seguro.

Ela também afirma que os prêmios do seguro poderiam servir de estímulo para as companhias melhorarem suas práticas de governança. Por meio da otimização contínua de suas estruturas de governança, as companhias poderiam pagar cada vez menos pelo seguro em relação a seus competidores, beneficiando-se ainda com retornos mais elevados e com o crescimento do valor de suas ações ${ }^{215}$.

Mediante a análise destas variáveis, Christine Kang finalmente concluiu que, se uma determinada companhia deixa de aprimorar suas práticas de governança e as companhias com as piores práticas pagam mais pelo seguro quando comparadas às

\footnotetext{
213، Using a sample of D\&O premiums gathered from the proxy statements of Canadian companies, this paper finds a detectable variation in $\mathrm{D} \& \mathrm{O}$ premiums that is related to variables that proxy for the quality of a firm's governance.” KANG, Christine, op. cit., p 66.

214،"Corporate governance is an important component of the insurer's pricing equation, because without taking this into account, insurers would be unable to differentiate between firms with otherwise identical business characteristics.” KANG, Christine, op. cit., p 16.

${ }^{215}$ Nas palavras de Christine Kang: "D\&O premiums could provide companies incentives to improve their corporate governance. By continually optimizing their governance structures, they can find themselves paying consistently less for $\mathrm{D} \& \mathrm{O}$ insurance than their competitors and enjoying higher earnings and improved share values." KANG, Christine, op. cit., p 68.
} 
companhias com melhores índices de governança, então os investidores podem adotar a precificação do seguro como uma informação precisa para avaliar a qualidade da governança corporativa de uma determinada companhia ${ }^{216}$.

No Brasil, assim como no Canadá, os emissores de valores mobiliários admitidos à negociação em mercados regulamentados de valores mobiliários estão obrigados a entregar anualmente à CVM o formulário de referência, que reune diversas informações sobre os emissores $^{217}$.

No campo "assembleia geral e administração" do formulário, os emissores devem “descrever as disposições de quaisquer acordos, inclusive apólices de seguro, que prevejam o pagamento ou o reembolso de despesas suportadas pelos administradores, decorrentes da reparação de danos causados a terceiros ou ao emissor, de penalidades impostas por agentes estatais, ou de acordos com o objetivo de encerrar processos administrativos ou judiciais, em virtude do exercício de suas funções".

Não obstante, diferentemente do conteudo mínimo das informações básicas exigidas no Canadá, a regulamentação pátria determina não exige que a companhia divulgue o valor do prêmio.

Fundamentada nos diversos estudos que sustentam a importância do valor do prêmio como indicativo da qualidade da governança corporativa, talvez fosse o caso de a CVM rever a regulamentação de modo a exigir que o valor do prêmio também fosse informado. Como constatou Christine Kang, esta informação pode ajudar a nortear as decisões dos investidores e ainda estimular melhores práticas de governança nas companhias $^{218}$.

\footnotetext{
${ }^{216}$ Conforme Christine Kang: "If firms fail to continually optimize their corporate governance and firms with worse corporate governance pay more for $\mathrm{D} \& \mathrm{O}$ insurance than firms with better governance, then investors can use D\&O pricing as an accurate proxy to evaluate the quality of a firm's corporate governance. KANG, Christine, op. cit., p 69.

${ }^{217}$ Conforme Instrução n ${ }^{\circ}$ CVM 480 de 7 de dezembro de 2009.

${ }^{218}$ Conforme Christine Kang: "The essence of the argument for disclosure, then, is that the information contained in $\mathrm{D} \& \mathrm{O}$ policies is potentially valuable for investors and can even encourage better governance practices within firms." KANG, Christine, op. cit., p. 22.
} 
Uma empresa de auditoria brasileira realizou, em 2010, um estudo sobre governança corporativa ${ }^{219}$ e, baseada nos dados do formulário de referência, examinou o índice de contratação de seguro de responsabilidade para os administradores e o volume dos prêmios pagos.

Do estudo, participaram 241 companhias listadas em diferentes segmentos de listagem da BM\&FBOVESPA (os segmentos de listagem são categorias pela BM\&FBOVESPA destinadas a companhias com melhores práticas de governança). Além do mercado tradicional, existem os segmentos de Novo Mercado (mais elevado padrão de governança), Nível 2 e o Nível $1^{220}$.

De acordo com o levantamento, o maior índice de contratação do seguro concentrou-se nas companhias listadas no segmento do Novo Mercado (77,6\%), seguido das companhias listadas nos Níveis 1 e $2(63,6 \%)$. No segmento tradicional, apenas $52 \%$ das companhias contrataram o seguro.

Em complemento a estes índices, vale conferir as diferenças nos valores do seguro em cada segmento. O valor médio dos prêmios pagos pelas companhias do Novo Mercado foi avaliado em $\mathrm{R} \$ 47.4$ milhões contra $\mathrm{R} \$ 62,5$ milhões pagos pelas companhias listadas nos Níveis 1 e 2.

É interessante notar que o resultado do levantamento do valor dos prêmios pagos pelas companhias é consistente com a hipótese de que as empresas com melhores práticas de governança pagam menos pelo seguro. Estes dados sinalizam, portanto, que a relação inversamente proporcional entre os prêmios de seguro de responsabilidade civil de administradores e a qualidade das práticas de governança corporativa possivelmente também opera no Brasil.

\footnotetext{
219، “A Governança Corporativa e o Mercado de Capitais: Um panorama atual das empresas abertas, com base nos seus Formulários de Referência”, Relatório KPMG Auditores Independentes, 2010-2011. Disponível em $<\underline{\text { http://www.kpmg.com/BR/PT/Estudos_Analises/artigosepublicacoes/Documents/RC_IARCS/Estudo_GC_ }}$ 2010_Final.pdf>. Acesso em 15.10.2012.

220“Basicamente, o segmento de Nível 1 caracteriza-se por exigir práticas adicionais de liquidez das ações e disclosure. Enquanto o Nível 2 tem por obrigação práticas adicionais relativas aos direitos dos acionistas e do conselho de administração. O Novo Mercado, por fim, diferencia-se do Nível 2 pela exigência para emissão exclusiva de ações com direito a voto." Conforme Instituto Brasileiro de Governança Corporativa: $<$ http://www.ibgc.org.br/Secao.aspx?CodSecao=20 > . Acesso em 15.10.2012.
} 


\subsubsection{CONSIDERAÇÕES SOBRE O RISCO MORAL (MORAL HAZARD) E O} SEGURO DE RESPONSABILIDADE CIVIL DE ADMINISTRADORES

A influência do risco moral nas operações de seguro tem sido debatida há tempos. Especificamente no ramo dos seguros de responsabilidade civil de administradores, tem-se estudado se o seguro pode ser utilizado como ferramenta para o chamado oportunismo gerencial.

Um estudo norte-americano realizado com uma amostra de 72 companhias que abriram o capital entre 1992 e 1996 revelou uma relação inversamente proporcional entre o valor da cobertura do seguro de responsabilidade civil oferecido no momento em que uma companhia realiza oferta pública inicial de ações e o desempenho de tal companhia nos três anos subsequentes à abertura de capital ${ }^{221}$.

De forma semelhante, pesquisadores chineses chegaram a importantes conclusões mediante análise de operações de fusões e aquisições realizadas por companhias abertas canadenses. Tais estudiosos constataram que, em operações de fusões e aquisições, as companhias adquirentes cujos administradores gozavam de proteção do seguro de responsabilidade civil tiveram retornos financeiros inferiores em relação a suas ações se comparadas a companhias adquirentes cujos administradores não estavam cobertos por tal seguro $^{222}$.

Constataram, ainda, que as más decisões tomadas por administradores envolvendo operações de fusões e aquisições verificam-se de duas formas: pelo pagamento de preço excessivo pela companhia adquirida (objeto da operação) e pela baixa sinergia com a

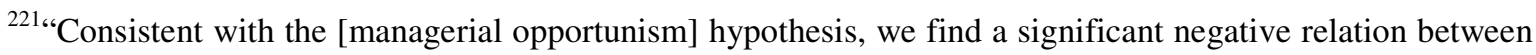
the 3-year post- IPO stock price performance and the amount of insurance coverage in place at the IPO date." CHALMERS, John, Dann, LARRY, Y., e HARFORD, Jarrad, Managerial Opportunism? Evidence from Directors' and Officers' Insurance Purchases, 2000, p. 1. Disponível em <http://ssrn.com/abstract=239222>. Acesso em 15.10.2012.

222، Using hand-collected D\&O insurance data for Canadian listed companies, we find that acquirers whose managers are protected by $\mathrm{D} \& \mathrm{O}$ insurance, or carry higher policy limits, experience significantly lower announcement-period abnormal stock returns than do acquirers without D\&O insurance (or those with low policy limits)." LIN, Chen, OFFICER, Micah S. e ZOU, Hong, Managerial Legal Liability Insurance and Acquisition Outcomes. Journal of Financial Economics (JFE), Forthcoming, p. 27. Disponível em $<$ http://ssrn.com/abstract=1641645 $>$. Acesso em 15.10.2012.
} 
companhia adquirida ${ }^{223}$. Concluíram, da mesma forma como o estudo norte-americano referido anteriormente, que o seguro pode guardar relação com situações de oportunismo gerencial $^{224}$.

Não obstante o resultado de tais pesquisas, outras tantas, inclusive mais recentes, sustentam que existem mecanismos efetivos de controle do risco moral pelas seguradoras e que, embora seja inviável dissociar este risco do seguro, não se pode suprimir o seguro por conta dele.

Steven Shavell, por exemplo, identificou duas maneiras pelas quais as seguradoras podem conter o risco moral, ainda que de forma parcial: (i) restringindo as coberturas ou oferecendo coberturas incompletas; e (ii) monitorando o nível de cuidado do segurado para prevenir os sinistros, a ser realizada tanto antes quanto após o fatoex post ${ }^{225}$. Este monitoramento inclui o acompanhamento da saude financeira da companhia mediante exame de suas demonstrações financeiras, avaliação de seu desempenho com base em índices mercadológicos, entre outras providências.

Nesta mesma linha, uma recente pesquisa (2011) realizada por Wim Weterings revelou um terceiro instrumento além do monitoramento do segurado já proposto por Shavell: a exposição parcial da companhia tomadora do seguro ou do próprio segurado ao $\operatorname{risco}^{226}$.

Wim Weterings explica que existem diversas formas de utilização deste terceiro mecanismo, tais como a inclusão de uma franquia na apólice (como já implementado na

\footnotetext{
223، Further analyses show that there are two channels through which the well-protected managers of firms with high D\&O policy limits make relatively poor M\&A decisions: overpayment for the target and low synergies with the target.” LIN, Chen, OFFICER, Micah S. e ZOU, Hong, op cit., p. 27.

224، Overall, our results are consistent with the argument that $\mathrm{D} \& \mathrm{O}$ insurance induces moral hazard on the part of managers by shielding them from the discipline of shareholder litigation. Our study complements existing studies which demonstrate that entrenched, or poorly governed, managers who are protected from shareholder discipline make poor decisions about major corporate investments." LIN, Chen, MICAH, S. e ZOU, Hong, op. cit., p. 27.

${ }^{225}$ Conforme SHAVELL, Steve, op. cit., p. 542.

${ }^{226}$ “" There are basically two instruments for reducing moral hazard. First, an insurer can monitor the policyholder and the insured party/parties and adjust the premium and the insurance conditions to their behaviour and the actual risk. In addition, moral hazard can be limited by partially exposing the policyholder and/or the insured party to the risk." WETERINGS, Wim. Directors' \& Officers' liability, D\&O insurance and moral hazard: more control of moral hazard by $D \& O$ insurers needed to increase the incentives of directors and supervisory board members, 2012, p. 8. Disponível em $<$ http://ssrn.com/abstract=2153129>. Acesso em 15.10.2012.
} 
Alemanha e no estado de Nova Iorque (EUA) por exigência das respectivas regulamentações locais) ${ }^{227}$, a redução do limite máximo de garantia e a inserção de exclusões de cobertura ${ }^{228}$.

Outra recente pesquisa (2012) na Universidade de Chicago (EUA) averiguou que o controle de riscos pelas seguradoras é por vezes mais eficiente do que os próprios órgãos reguladores ou o judiciário. A acirrada concorrência no mercado securitário e o incentivo de contenção de custos após o pagamento dos prêmios estimulam as seguradoras a buscar mecanismos efetivos para mitigação de ris $\cos ^{229}$.

Estes mecanismos vão desde exigir que o tomador ou segurado realizem investimentos específicos para reduzir o risco até a venda de expertise sobre contenção de custo para os tomadores. Em muitas situações, a vantagem comparativa que as seguradoras têm em relação aos reguladores por terem acesso a certas informações confidenciais faz com que as seguradoras desempenhem o papel de controladoras de risco de forma mais eficiente que o poder público ${ }^{230}$.

Peter Egger et al. vão ainda mais longe e refutam a hipótese de que o seguro de responsabilidade civil de administradores cria um risco moral, justificando seu posicionamento com informações reiteradamente fornecidas pelas seguradoras entrevistadas em seu estudo. De acordo com o levantamento feito, em primeiro lugar, as violações da lei, tais como a fraude, tornam automaticamente nulo o contrato de seguro.

Em segundo lugar, justificam que os contratos de seguro deste ramo não são produtos padronizados - há uma quantia considerável de monitoramento, incluindo a inspeção do histórico de executivos e discussões acerca do regime de governança

\footnotetext{
${ }^{227}$ WETERINGS. Wim, op. cit., p. 15.

${ }^{228}$ WETERINGS. Wim, op. cit., p. 11.

${ }^{229}$ "It is the pressure of competition, and the selfish incentive to contain costs once premiums have been paid, that motivates insurer to seek risk mitigation. Insurers regulate risk in various ways." BEN-SHAHAR, Omri e LOGUE, Kyle D., Outsourcing Regulation: How Insurance Reduces Moral Hazard, in Working paper No. 12-004, Faculdade de Direito da Universidade de Chicago, 2012, p. 53.

${ }^{230}$ "From mandating specific investments in risk reduction, to offering premium discounts for favorable claims experience, to selling cost-containment expertise to policyholders, insurers perform many of the same regulatory functions that government regulators and courts perform. However, in many (though obviously not all) situations, private insurers, because of their inherent informational comparative advantage, should be expected to do the job of regulation better than public regulators and courts. BEN-SHAHAR, Omri e LOGUE, Kyle D., op. cit., p. 53.
} 
corporativa, realizados antes da conclusão do contrato. Quando as seguradoras possuem dúvidas quanto à idoneidade do segurado, em geral, optam por não firmar o contrato. Assim, a assimetria de informação não parece ter um papel significante no contexto deste $\operatorname{mercado}^{231}$.

Concluem, pois, que a hipótese de que a disponibilidade do seguro de responsabilidade civil de administradores cria um problema de risco moral não parece justificada, pois as informações assimétricas não parecem ser de grande relevância ${ }^{232}$.

\subsubsection{ADMISSIBILIDADE DO SEGURO DE RESPONSABILIDADE CIVIL DE ADMINISTRADORES NO DIREITO BRASILEIRO}

O exame dos regimes de responsabilidade, associado à análise da aplicabilidade do seguro de responsabilidade civil, oferece elementos para discussão da admissibilidade do seguro de responsabilidade civil.

Conquanto se deva admitir que, em virtude (i) das dificuldades que se colocam na apuração do dolo ou culpa do segurado; (ii) do contexto de ações de responsabilidade no Brasil; e (iii) da noção de proteção absolutamente eficaz que o seguro pode equivocadamente transmitir aos administradores, o seguro de responsabilidade civil dos administradores possa sim estar associado ao risco moral, à assunção de riscos mais elevados na condução dos negócios empresariais e até mesmo a fraudes, sua utilização apresenta, a nosso ver, mais vantagens que desvantagens.

É sabido que, conforme estudado, o risco subjetivo, assim entendido o conjunto de qualidades psíquicas e comportamentais inerentes ao segurado que pode interferir positiva

\footnotetext{
231،In discussions with insurers we were given as possible explanations for this: first, the fact that legal infringements such as fraud and deception automatically nullify the insurance contract, and secondly, that these contracts are not 'over the counter' standard products - a considerable amount of monitoring, including inspection of the records of directors and executives, and discussion of the company's corporate governance regime, takes place before the contract is concluded. Where insurers have serious doubts, we were told, they prefer not to offer the contract. Thus it would seem that asymmetric information between insurer and insured does not play a significant role in this market." EGGER, Peter, RADULESCU, Doina, REES, Ray. Corporate Governance and Managerial Incentives: Evidence from the Market for D\&O Insurance,2011, p. 5. Disponível em <http://www.wu.ac.at/egrie2011/programme/papers/v.b3.radulescu.pdf $>$. Acesso em 15.10.2012.

232، The concern that the availability of D\&O insurance creates a moral hazard problem does not seem justified: asymmetric information does not appear to be significant [...]". EGGER, Peter, RADULESCU, Doina, REES, Ray, op. cit., p. 19.
} 
ou negativamente na ocorrência do sinistro, e o risco moral não são de fácil mensuração pela seguradora, razão pela qual o seguro poderia, de fato, ser utilizado pelo administrador para finalidade diversa daquela a que se propõe.

Os inconvenientes que o seguro apresenta, no entanto, parecem menos relevantes diante da sua serventia aos administradores probos, aos investidores, ao mercado e ao Estado pelas seguintes razões:

1. As limitações à aplicabilidade do seguro, bem como as hipóteses de afastamento da cobertura securitária, restringem consideravelmente as manobras de administradores que desejem se aproveitar do seguro para agir em desalinho com a conduta dele esperada, minimizando as brechas que possam dar margem a fraude.

2. Embora o terceiro reclamante eventualmente prejudicado por dano decorrente de ato do administradores não seja, do ponto de vista jurídico, o beneficiário efetivo da indenização securitária, não se pode negar que tal terceiro tem seu interesse indiretamente tutelado pelo seguro.

3. O florescimento do mercado de capitais brasileiro, acompanhado da migração do modelo de capital concentrado para o modelo de capital disperso e de controle difuso, à luz do modelo norte-americano, pode representar um aumento de demandas de acionistas contra o administrador, o que sugere um potencial aumento na sinistralidade. Com isso, o seguro mostra-se decisivo para proteger os administradores das companhias.

4. O seguro estimula boas práticas de governança corporativa no âmbito das companhias, sendo ainda o prêmio pago pelo seguro um bom indicativo da qualidade da governança de uma companhia.

5. O seguro não mitiga o risco de os administradores serem pessoalmente responsabilizados por sua conduta, mas somente repara os efeitos patrimoniais decorrentes de sua responsabilização. Assim, não se pode dizer que o seguro premia o administrador que falta com seus deveres fiduciários ou que age com dolo, pois, a despeito do seguro, ele permanece obrigado a responder administrativa, civil e penalmente por seus atos. 
6. A tomada de risco (no âmbito dos negócios) e o empreendedorismo são inerentes ao exercício da atividade empresarial e, dada a relevância desta atividade para o desenvolvimento econômico e social do país, o seguro desempenha papel fundamental para evitar que o progresso desta última seja engessado pelo temor dos administradores de se verem obrigados a reparar danos a terceiros relacionados a sua gestão ${ }^{233}$.

7. A proteção intentada pelo seguro parece em linha com a preocupação da LSA ao estabelecer um padrão de comportamento amplo que busca, entre outros objetivos, evitar que administradores probos sejam desestimulados a a ocupar cargos de gestão ${ }^{234}$.

8. Embora não seja possível eliminar completamente o risco moral, as restrições à aplicabilidade do seguro, bem como outras medidas que as seguradoras podem tomar para controlar este risco, tendem a conter o mau-uso do seguro.

9. A própria dinamicidade dos mercados pode gerar repentinas alterações no curso do cenário econômico de um determinado período, fazendo com que até mesmo decisões acertadas naquele contexto venham a ter consequências indesejadas. $\mathrm{O}$ segurado, ainda que tenha tido a intenção de praticar o ato, pode não necessariamente ter intentado provocar os resultados dele decorrentes ${ }^{235}$.

10. No contexto do risco empresarial e empreendedorismo ora mencionados e da relativa discricionariedade, independência e autonomia de que gozam os

\footnotetext{
${ }^{233}$ Segundo HAN et al., os principais argumentos favoráveis à aquisição do seguro de responsabilidade civil de administradores incluem o fato de o seguro atrair e manter indivíduos talentosos para atuar como administradores e a ausência do seguro poder estimular uma gestão conservadora, que parece pouco provável ser do interesse dos acionistas. "The major arguments in support of corporate purchase of D\&O insurance include; (i) $\mathrm{D} \& \mathrm{O}$ insurance can attract and retain talented individuals to serve as directors; and (ii) the absence of insurance may encourage conservative management, which is unlikely to be in the interests of the shareholders." HAN, Li-Ming, MACMINN, Richard D. e REN, Yayuan. Directors and Officers Insurance and Corporate Governance, p. 5. Disponível em <http://ssrn.com/abstract=1722289 $>$. Acesso em 15.10.2012.

${ }^{234}$ Luiz Antonio de Sampaio Campos, ao tratar do padrão de comportamento previsto na LSA, afirma que a liberdade típica das cláusulas gerais e dos conceitos jurídicos indeterminados deve ser usada de forma inteligente e cuidadosa, de forma a "manter o sistema íntegro, para não desencorajar e afastar pessoas honestas e competentes dos cargos de administradores, e também de modo a não criar um sistema que as entorpeça de ação com uma burocracia prejudicial à vida da companhia, afastando-as do risco inerente ao negócio." CAMPOS, Luiz Antonio de Sampaio, op. cit., p. 1087.

${ }^{235}$ Conforme PICARD, M. e BESSON, A., op. cit., p. 116-117. Tais autores colocam ainda que uma conduta como esta comporta um risco, visto que parte dela fica sujeito ao acaso. Circunstâncias externas podem afetar sobremaneira os resultados da conduta do agente, sem que este tenha pretendido gerar as consequências dela decorrentes.
} 
administradores no exercício de sua gestão ${ }^{236}$, não parece adequado suprimir o seguro, privando os administradores probos do amparo securitário (que nos parece indiscutivelmente pertinente neste caso), sob pena, inclusive, de incapacitar o mercado de reter talentos ${ }^{237}$.

Poder-se-ia dizer ainda que o administrador que acredita ser o seguro uma verdadeira blindagem tem uma visão demasiada simplista dos reais impactos que as reclamações de terceiros fazem recair sobre ele. A proteção do seguro, como visto, é meramente patrimonial.

Os efeitos de uma responsabilização pessoal não se reduzem ao ônus sobre o patrimônio. Como visto, as consequências da imputação da responsabilidade (e, às vezes, até mesmo da mera existência de processos em que figure como réu) podem afetar a reputação do administrador, sua empregabilidade e sua habilitação para exercer o cargo, bem como interferir negativamente na futura contratração de seguro de responsabilidade.

Destarte, seria de se supor que o administrador que possui a exata dimensão dos efeitos extrapatrimoniais que sua responsabilização pessoal pode acarretar não encararia o seguro como uma carta branca para tomada desmedida de riscos ou para desmandos no âmbito da administração das companhias.

Por fim, ainda que o administrador mostre-se alheio a tais resultados extrapatrimoniais, atendo-se apenas ao desejo de conservação de seu patrimônio, o seguro não necessariamente abrangerá todas as quantias que o administrador possa vir a ser obrigado a pagar, haja vista (i) as limitações inerentes ao próprio seguro, tais como previstas na apólice (i.e., limite máximo da garantia, compartilhamento de cobertura); e (ii) a conduta do administrador, seja sob a perspectiva da responsabilidade (associada ao conteúdo do ato ou fato que ensejou reclamação de terceiro), seja sob a perspectiva do

\footnotetext{
236،Não se pode negar, na experiência concreta, que se defere aos administradores certa margem de discricionariedade na condução dos negócios sociais, pois nem a lei nem o estatuto poderão jamais definir, com exatidão e amplitude exaustiva, as condições específicas de legitimação dos gestores à prática dos chamados atos regulares de gestão, individualmente considerados." GUERREIRO, José Alexandre Tavares, Responsabilidade dos Administradores de Sociedades Anônimas, in Revista de Direito Mercantil, Industrial, Econômico e Financeiro, ano XX (nova série), nº 42, São Paulo: RT, abril/junho 1981, p. 74.

237،"Without D\&O insurance, directors and officers put their personal assets, which as often substantial, at risk when they agree to serve. In order to attract and retain capable and skilled directors and officers, then, D\&O has become a practical necessity in today's litigious corporate environment. KANG, Christine. op. cit., p. 4.
} 
seguro (associada aos atos ou fatos declarados no momento da contratação do seguro e ao comportamento do segurado frente ao risco e à ocorrência do sinistro). 


\section{CONCLUSÃO}

O seguro de responsabilidade civil de administradores - seguro que, respeitados os limites legais e os limites previstos na apólice, tem por objeto ressarcir os segurados de custos, indenizações e outras quantias que venham a despender em razão de reclamações de terceiros - é um instrumento de especial relevância no âmbito da administração das companhias.

Sua importância revela-se tanto sob a ótica do administrador - que recebe um estímulo e um conforto adicional para exercer a gestão da companhia por atuar o seguro na contenção dos impactos patrimoniais decorrentes de reclamações de terceiros - quanto sob a ótica dos terceiros que eventualmente demandem o administrador, sejam eles acionistas, investidores, a comunidade e o próprio Estado, visto que o seguro garante, até certo ponto, que o administrador tenha recursos suficientes para fazer frente às indenizações devidas a tais terceiros.

Embora amplamente difundido em todo o mundo, sua utilização no âmbito da administração das companhias ainda suscita uma série de questionamentos, sobretudo no que diz respeito ao risco moral (moral hazard) associado ao exercício da administração. Discute-se, portanto, se a existência dos seguros não serviria de mau-incentivo para os administradores que, munidos do seguro, poderiam realizar gestões mais agressivas ou mesmo faltar com seus deveres e obrigações.

Para sopesar os prós e contras do seguro e ponderar sobre a questão do risco moral, este trabalho examinou, com base na experiência estrangeira e nas informações prestadas por seguradoras brasileiras que atuam fortemente no ramo de seguros de responsabilidade, situações recorrentes em que se discute a aplicabilidade do seguro.

Ao analisar tais situações, verificou-se que a atuação do administrador é um dos principais elementos levados em conta na determinação da aplicabilidade do seguro. Constatou-se que, em diversas hipóteses, a conduta do administrador pode afastar a aplicação do seguro, tanto sob a perspectiva societária (e.g., prática de ato doloso no 
exercício da gestão), como sob a perspectiva securitária (e.g., declaração falsa no momento da contratação do seguro e notificação de ato ou fato agravante do risco subscrito).

Ademais, características inerentes à própria apólice - e que não necessariamente se relacionam ao comportamento do segurado - também restringem a aplicabilidade do seguro. São exemplos destas características o valor máximo garantido pelo contrato (uma vez alcançado o teto previsto na apólice, o administrador não mais poderá buscar indenização securitária) e possibilidade de utilização do seguro para cobertura de multas (tema ainda em discussão pelas autoridades brasileiras competentes).

Conforme os dados levantados neste trabalho, as numerosas limitações e condicionantes à aplicabilidade deste seguro, embora não eliminem completamente o risco moral, podem agir como contentores deste risco. Isto porque referidas limitações e condicionantes evidenciam que diversas são as circunstâncias em que o administrador, ainda que beneficiário de um seguro de responsabilidade civil, se veja obrigado a arcar com reclamações de terceiros com recursos próprios.

A este respeito, vale lembrar que a discussão sobre a relação entre o seguro e o incremento do risco moral não é pacífica. Muitos estudos intentaram estabelecer esta relação mediante análise de fatores como (i) a influência do seguro na governança das companhias; (ii) a criação, pelo seguro, de situações favorecedoras de oportunismo gerencial; e (iii) as diferenças entre os retornos financeiros auferidos por companhias após a conclusão de operações capitaneadas por administradores que possuíam e que não possuíam o seguro.

Não obstante alguns indicadores da efetiva existência do risco moral associado ao seguro de responsabilidade civil de administradores, boa parte destes estudos constatou que tais indicadores não são conclusivos e, mesmo que o fossem, não seriam o bastante para justificar a supressão deste seguro.

Neste contexto, conquanto não se possa olvidar a existência de elementos de conexão entre o seguro e o risco moral, os benefícios trazidos pelo seguro parecem sobrepujar as desvantagens (majoritariamente voltadas para o risco moral) que ele apresenta. 
Ao analisar a influência destes elementos especificamente no âmbito do direito brasileiro, este trabalho verificou que os entraves à apuração do dolo ou culpa do administrador, aliados ao contexto de ações de responsabilidade no Brasil, podem influir na criação do risco moral.

Em nosso entender, entretanto, este canário não prejudica a admissibilidade do seguro de responsabilidade civil de administradores pelo direito brasileiro. A contraposição das vantagens e desvantagens apresentadas por este seguro nos leva a advogar por seu acolhimento pelo arcabouço jurídico pátrio na medida em que os argumentos favoráveis à manutenção deste seguro parecem superar os argumentos contrários a ela.

Além de beneficiar, ainda que indiretamente, os terceiros eventualmente prejudicados por atos do administrador, este estou averiguou que o seguro está linha com os deveres gerais previstos na LSA e pode atuar como medidor das práticas de governança corporativa adotadas pelas companhias.

Ademais, os limites à aplicabilidade deste seguro, bem como as hipóteses de afastamento da cobertura securitária, levam a crer que este seguro não necessariamente motivará os administradores a assumir riscos desmedidamente ou a se absterem de seus deveres e obrigações no exercício da gestão social.

Neste diapasão, cumpre ressaltar ainda que as consequências geradas por uma reclamação de terceiro não estão adstritas ao impacto patrimonial, pois a responsabilização pessoal do administrador pode afetar sua reputação e a da companhia na qual atua. Por isso, parece justo que os administradores probos e honestos, cientes destas consequências, possam contar com o seguro para desempenhar suas atribuições sem receio dos eventuais efeitos adversos inerentes ao exercício da atividade empresarial.

Embora a temática deste trabalho seja ainda bastante recente no Brasil e, como tal, mereça ser estudada mais a fundo pelos doutrinadores brasileiros, a análise circunstanciada da aplicabilidade do seguro de responsabilidade civil de administradores no âmbito da administração das companhias brasileiras já revela a existência de número considerável de elementos que refutam o pensamento de que a utilização deste seguro incita os 
administradores a agirem com menor grau de diligência e a assumir mais riscos empresariais. 


\section{REFERÊNCIAS BIBLIOGRÁFICAS}

ABRAHAM, Kenneth S., Insurance law and regulation - cases and materials, $4^{\mathrm{a}}$ ed., Nova Iorque, Thomson West, 2005.

ADAMEK, Marcelo Vieira von. Responsabilidade civil dos administradores de S/A e as ações correlatas, São Paulo: Saraiva, 2009.

ALVIM, Pedro, O Contrato de Seguro, $3^{\text {a }}$ ed., Rio de Janeiro: Forense, 1999.

O Seguro e o Novo Código Civil, Rio de Janeiro: Forense, 2007.

Responsabilidade Civil e Seguro Obrigatório, São Paulo: Revista dos Tribunais, 1972.

AZEVEDO, Luis Augusto Roux. A Comutatividade do Contrato de Seguro, Dissertação de mestrado pela Faculdade de Direito da Universidade de São Paulo, São Paulo: 2010.

BAKER, Tom. The Missing Monitor in Corporate Governance: The Directors' \& Officers' Liability Insurer. In Georgetown Law Journal, v. 95, 2007.

; GRIFFITH, Sean J. Predicting Corporate Governance Risk: Evidence from the Directors' and Officers' Liability Insurance Market, Chicago Law Review, v. 74, 2007.

; SIEGELMAN, Peter. The Law and Economics of Liability Insurance: A Theoretical and Empirical Review. Disponível em <http://ssrn.com/abstract=1783793>. Acesso em 15.5.2011.

BEN-SHAHAR, Omri e LOGUE, Kyle D. Outsourcing Regulation: How Insurance Reduces Moral Hazard. Working paper No. 12-004, Faculdade de Direito da Universidade de Chicago, 2012. 
BIGOT, Jean. Traité de Droit des Assurances, Paris: Librarie Générale de Droit et de Jurisprudence, 1992.

BITTLE, Lyndon F. An Overview of Insurance Coverage Disputes. National Business Institute Seminar, 2008. Disponível em <http://www.ccsb.com/pdf/Publications/ Insurance/Ins_coverage_disputes.pdf $>$. Acesso em 15.10.2012.

, SUTHERLAND, J. Michael, BARNHOUSE, Shelbi, POCSIK, Stephen. Insurance and Indemnification of Directors and Officers: Avoiding Pitfalls. Disponível em $<$ http://www.ccsb.com/pdf/Publications/Insurance/Avoiding_Pitfalls_2011.pdf $>$. Acesso em 15.10.2012.

BOYER, M. Martin. Directors' and Officers' Insurance and Shareholder Protection. Disponível em <http://ssrn.com/abstract=886504>. Acesso em 15.10.2012.

Is the Demand for Corporate Insurance a Habit? Evidence from the Directors' and Officers' Insurance. In Série Scientifique - Centre Interuniversitaire de Recherche en Analyse des Organisations, Montréal, 2003.

AMANDINE, Hanon. Protecting Directors and Officers from Liability Arising from Aggressive Earnings Management. Disponível em $<$ http://ssrn.com/abstract=1504208 $>$. Acesso em 15.10.2012.

BUCHANAN J. M. The Inconsistencies of the National Health Service, Inst. of Econ. Affairs Occas, Paper 7, Londres, 1964.

BULGARELLI, Waldírio. Apontamentos sobre a responsabilidade dos administradores das companhias, in Revista de Direito Mercantil, Industrial, Econômico e Financeiro $\mathrm{n}^{\mathrm{o}}$ 50, Abril/Junho, 1983.

Comentários à lei das sociedades anônimas, v.4, São Paulo: Saraiva, 1978. 
CALERO, Fernando Sanchez. Curso de Derecho del Seguro Privado, v. I, Bilbao: Ediciones Nauta, 1961.

CAMPBELL, Sharie-Ann J. Controlling Executive Compensation - Directors' and Officers' Liability Insurance: A Proposed Solution to Inflated Pay. Disponível em $<$ http://ssrn.com/abstract=1595091>. Acesso em 15.10.2012.

CAMPOS, Luiz Antonio de Sampaio. Deveres e Responsabilidades. Direito das Companhias (org. Alfredo Lamy Filho e José Luiz Bulhões Pedreira), v. 1, Rio de Janeiro: Forense, 2009.

CARVALHOSA, Modesto. Responsabilidade civil de administradores e de acionistas controladores perante a Lei das S/A, in Revista dos Tribunais, v. 699, nº 83, jan. 1994.

CHALMERS, John, LARRY, Dann Y., HARFORD. Jarrad, Managerial Opportunism? Evidence from Directors' and Officers' Insurance Purchases, 2000. Disponível em $<$ http://ssrn.com/abstract=239222>. Acesso em 15.10.2012.

COMPARATO, Fábio Konder. O seguro de crédito - estudo jurídico, São Paulo: Revista dos Tribunais, 1968.

CORE, John E. On the Corporate Demand for Directors' and Officers' Insurance, The Journal of Risk and Insurance, v. 64, No. 1, 1997.

, John E. The Directors' and Officers' Insurance Premium: An Outside Assessment of the Quality of Corporate Governance, maio/2000. Disponível em $<\mathrm{http}: / /$ ssrn.com/abstract=229803>. Acesso em 15.10.2012.

CORREIA, Luis Brito. Os administradores de sociedades anônimas, Coimbra: Livraria Almedina, 1993.

COUILBAULT, François. Les grands principes de l'assurance. Paris : L'Argus, 2003. 
DIAS, José Aguiar. Da responsabilidade Civil, v. II, Rio de janeiro: Forense, 1997.

. Da responsabilidade Civil, 11 a ed., Rio de Janeiro: Renovar, 2006.

DICKERSON, O.D. Health Insurance, Ed. Homewood, 1963.

DICKEY, Jonathan C. e SELS, John D. Van Loben. Indemnification and Insurance for Directors and Officers of Public Companies: What directors and officers need to know in the post-Sarbanes-Oxley World, Washingtion, Gibson, Dunn\&Crutcher LLP, 2003.

DONATI, Antigono. Los Seguros Privados - Manual de Derecho, Barcelona: Libreria Bosch, 1960.

, e PUTZOLU, Giovanna Volpe. Manuale di Diritto delle Assicurazioni Private. $3^{\mathrm{a}}$ ed., Milano: Dott. A. Giuffrè Editore, 1987.

DONLEY, Steven, KENT, Nigel P. Directors and Officers Liability in Canada: A Review of Exposures and Coverages Available under D\&O Policies, 2008. Disponível em $<$ https://www.cwilson.com/publications/insurance/directors-officers-liability-in-canada.pdf>. Acesso em 15.10.2012;

EGGER, Peter, RADULESCU, Doina, REES, Ray. Corporate Governance and Managerial Incentives: Evidence from the Market for D\&O Insurance, 2011. Disponível em <http://www.wu.ac.at/egrie2011/programme/papers/v. b3.radulescu.pdf> . Acesso em 15.10.2012.

EIZIRIK, Nelson, et al. Mercado de Capitais - Regime Jurídico, Rio de Janeiro: Renovar, 2008.

Responsabilidade Civil dos Administradores da Sociedade Anônima, in Sociedade Anônima - I Ciclo de Conferência para Magistrados. Rio de Janeiro: IBCB, 1993. 
Responsabilidade Civil e Administrativa do Diretor de Companhia Aberta, in Revista de Direito Mercantil, Industrial, Econômico e Financeiro, ano XXIII, n ${ }^{\circ}$ 56, Outubro/Dezembro, 1984.

ENGEL, David M. e MCCANN, Michael. Tort Law as Cultural Practice. Buffalo Legal Studies Research Paper No. 2009-15. Disponível em <http://ssrn.com/abstract=1431501>. Acesso em 15.10.2012.

FARIA, Clara Beatriz Lourenço de. O seguro D\&O como instrumento de proteção patrimonial dos administradores de sociedades limitadas e anônimas. Monografia de Pós Graduação - Ínsper Instituto de Ensino e Pesquisa: São Paulo, 2010.

FIER, Stephen G., MCCULlOUGH, Kathleen A. GABEL, Joan T. A. e MANSFIELD, Nancy R. The Directors and Officers Insurance Marketplace: An Empirical Examination of Supply and Demand in Uncertain Times, 2009. Disponível em $<$ http://ssrn.com/abstract=1524063 > . Acesso em 15.10.2012.

FONSECA, Priscila M. P. Corrêa. Contrato de Seguro. Contratos Nominados - Doutrina e Jurisprudência, São Paulo: Saraiva, 1995.

FRANÇA, Erasmo Valladão Azevedo e Novaes, Invalidade das deliberações de assembleia das S.A., São Paulo: Malheiros, 1999.

FRANCO, Vera Helena de Mello. Contrato de seguros, São Paulo: Revista dos Tribunais, 1990.

Contratos - direito civil e empresarial. $2^{\mathrm{a}}$ ed., São Paulo: Revista dos Tribunais, 2011.

Lições de Direito Securitário - Seguros Terrestres Privados, São Paulo: Maltese, 1993.

Operação de seguro e sua qualificação jurídica, in Revista de Direito Mercantil, Industrial, Econômico e Financeiro, São Paulo, n. 67, p. 39-56, jul./set. 1987. 
GARCIA, Basileu. Instituições de direito penal, v. 1, t.1, 4ª ed., São Paulo: Max Limonad, 1968.

GASPERONI, Nicola. Assicurazioni Private, Padova: Casa Editrice Dott. Antonio Milani, 1972.

GONÇALVES, Carlos Roberto. Direito Civil Brasileiro, v. 4, $4^{\mathrm{a}}$ ed., São Paulo: Saraiva, 2009.

Direito Civil Brasileiro: contratos e atos unilaterais, v. 3, São Paulo:

Saraiva, 2004.

GRIFFITH, Sean J. Unleashing a Gatekeeper: Why the SEC Should Mandate Disclosure of Details Concerning Directors' \& Officers' Liability Insurance Policies. University of Penn, Inst for Law \& Econ Research Paper No. 05-15, 2005.

GUERREIRO, José Alexandre Tavares. Responsabilidade dos Administradores de Sociedades Anônimas, in Revista de Direito Mercantil, Industrial, Econômico e Financeiro, Ano XX (nova série), nº 42, São Paulo: RT, abril/junho 1981.

GUERREIRO, Marcelo da Fonseca. Seguros privados - doutrina, legislação, jurisprudência, $2^{\mathrm{a}}$ ed., Rio de Janeiro: Forense Universitária, 2004.

HALPERIN, Isaac. Seguros, vols. 1 e 2, 2a ed., Buenos Aires: Ediciones Depalma, 1983.

HAN, Li-Ming, MACMINN, Richard D. e REN, Yayuan. Directors, Directors and Officers Insurance and Corporate Governance. Disponível em $<$ http://ssrn.com/abstract=1722289 $>$. Acesso em 15.10.2012.

HERRMANNSDORFER, Fritz. Seguros privados, Madrid: Labor, 1933.

HILL, Jennifer G. Regulatory Responses to Global Corporate Scandals. Wisconsin International Law Journal, v. 23, 2005. 
JANSSENS, André. L'assurance de responsabilité, Bruxelles: F. Larcier, 1961.

KALCHEV, George. The Demand for Directors' and Officers' Liability Insurance by US Public Companies. Disponível em <http://ssrn.com/abstract=565183>. Acesso em 15.10.2012.

KANG, Christine. Directors' and Officers' Insurance: Ordinary Corporate Expense or Valuable Signaling Device?, Departamento de Economia da Universidade de Stanford, 2011. Disponível em <http://economics.stanford.edu/files/Kang_HThesis2011.pdf > . Acesso em 15.10.2012.

LAMY FILHO, Alfredo e PEDREIRA, José Luiz Bulhões. A Lei das S.A., Rio de Janeiro: Ronovar, 1992.

Direito das Companhias, v.1, Rio de Janeiro: Forense, 2009.

LIN, Chen, OFFICER, Micah S. e ZOU, Hong. Managerial Legal Liability Insurance and Acquisition Outcomes. Journal of Financial Economics (JFE), Forthcoming. Disponível em <http://ssrn.com/abstract=1641645>. Acesso em 15.10.2012.

MACHADO, Hugo de Brito. Responsabilidade Penal no Âmbito das Empresas, in Direito Penal Empresarial, São Paulo: Dialética, 2001.

MAIA, Roberta Mauro Medina e BURMAN, Leonardo Joseph. Apontamentos sobre o seguro de responsabilidade civil ara atos de gestão de administradores ou diretores de empresas ( $D \& O)$, in Revista Trimestral de Direito Civil, v. 8, $\mathrm{n}^{\circ}$ 30, Rio de Janeiro, 2007.

MARTINS, Fran. Contratos e obrigações comerciais, 16 ${ }^{\mathrm{a}}$ ed., Rio de Janeiro: Forense, 2010.

MARTINS, João Marcos Brito. Direito de Seguro: responsabilidade civil das seguradoras: doutrina, legislação jurisprudência de acordo com o novo código civil (Lei 10.406 de 10.1.2002), Rio de Janeiro: Forense Universitária, 2002. 
MAZEAUD, Henri; MAZEAUD, Léon. Traité théorique et pratique de la responsabilité civile délictuelle et contractuelle, v. 3, Paris: Recueil Sirey, 1931.

MEIRELLES, Hely Lopes. Direito Administrativo Brasileiro. (atual. por Eurico de Andrade Azevedo, Délcio Balestero Aleixo e José Emmanuel Burle F.), 21 a ed., São Paulo: Malheiros, 1996.

MELO, Gustavo de Medeiros. A ação direta do terceiro prejudicado no seguro de responsabilidade civil: uma análise do sistema jurídico brasileiro, in Revista Brasileira de Direito do Seguro e da Responsabilidade Civil, v. 1, nº 1, São Paulo: 2009.

MERKIN, Robert. Directors' and Officers' Insurance and the Global Financial Crisis, Australian Insurance Law Association (Geoff Masel Memorial Lectures), Australia: 2009.

MIRANDA, Francisco Cavalcanti Pontes de. Teoria de Direito Privado - Direito das Obrigações, vols. 45-46-47, Campinas: Bookseller, 2006.

NORONHA, E. Magalhães. Direito penal, v. 1, 4ª ed., São Paulo: Saraiva, 1967.

OSSA G., J. Efrén. Teoría General del Seguro - La Institución : Aspectos técnicos, económicos, políticos y comerciales del seguro, Bogotá: Temis, 1988.

PAOLINI, Adolfo; e NAMBISAN, Deepak. Directors and Officers' Liability Insurance, Londres: Informa, 2008.

PARENTE, Flavia. O Dever de Diligência dos Administradores das Sociedades Anônimas, Rio de Janeiro: Renovar, 2005.

PEARSON, Robin. Moral Hazard and the assessment of insurance risk in eighteenth and early nineteenth centrury Britain. Disponível em <http://www.jstor.org/discover/ $\underline{10.2307 / 4127750 \text { ?uid }=3737664 \& \text { uid }=2 \& \text { uid }=4 \& \text { sid }=21101174909363}>$.. Acesso em 15.10.2012. 
PEREIRA, Caio Mário da Silva. Responsabilidade civil, 9ª ed., Rio de Janeiro: Forense, 2001.

PICARD, M. e BESSON, A. Les Assurances Terrestres. Tome Premier, 5a ed, Paris: Librarie Générale de Droit et de Jurisprudence, 1982.

PRIEST, George L. Insurability and Punitive Damages. Faculty Scholarship Series. Paper 614, 1989. Disponível em <http://digitalcommons.law.yale.edu/fss_papers/614>. Acesso em 15.10.2012.

RIBEIRO, Amadeu Carvalhaes. Direito de seguros: resseguro, seguro direto e distribuição de serviços, São Paulo: Atlas, 2006.

ROBERTS, James. Can a D\&O policy be used to cover directors' fines? Disponível em <http://clydeco.com/uploads/Files/BLG/legal_updates/Articles/Can\%20a\%20D\&O\%20pol icy\%20be\%20used\%20to\%20cover\%20directors'\%20fines.pdf>. Acesso em 15.10.2012.

RODRIGUES, Ana Carolina. A responsabilidade civil dos administradores de companhias abertas não financeiras por danos causados à sociedade $e$ aos acionistas $e$ o desenvolvimento do mercado de valores mobiliários brasileiro. Tese de Mestrado em Direito pela Fundação Getúlio Vargas - Escola de Direito, São Paulo: 2011.

RODRIGUES, Silvio, Direito Civil - Responsabilidade Civil, 19ª ed., São Paulo: Saraiva, 2002.

SÁNCHEZ, Antonio Roncero. El Seguro de Responsabilidad Civil de los Administradores. Revista Para El Análsis Del Derecho - Facultad de Derecho Universidad de Castilla-La Mancha, Bercelona, 2005.

SHAVELL, Steven. On moral hazard and insurance, in The Quarterly Journal of Economics, Harvard University, Publicado por John Wiley and Sons, Inc., 1979. 
On the Social Function and the Regulation of Liability Insurance. Geneva Papers on Risk and Insurance Theory, Harvard Law School, 2000. Disponível em $<\mathrm{http}: / /$ ssrn.com/abstract=224945>. Acesso em 15.10.2012.

SIEGELMAN, Peter. Adverse Selection in Insurance Markets: An Exaggerated Threat. Fordham School of Law, Pub-Law Research Paper No. 27, 2003.

SILVA, Alexandre Couto. Responsabilidade dos administradores de S.A.: Business Judgement Rule, Rio de Janeiro: Campus, 2007.

SILVA, José Afonso da. Direito Ambiental Constitucional, $5^{\text {a }}$ ed., São Paulo: Malheiros, 2004.

STERN, Lea H., e BOYER, M. Martin. Is Corporate Governance Risk Valued? Evidence from Directors' and Officers' Insurance, 2010. Disponível em $<$ http://ssrn.com/abstract=1571752 $>$. Acesso em 15.10.2012.

STIGLITZ, Rubén S. El contrato de seguro, Buenos Aires: Abeledo-Perrot, 1994.

THEODORO JÚNIOR, Humberto. O contrato e sua função social, $2^{\mathrm{a}}$ ed., Rio de Janeiro: Forense, 2004.

TOLEDO, Paulo Fernando Campos Salles de. O Conselho de Administração na Sociedade Anônima. Estrutura, Funções e Poderes, Responsabilidade dos Administradores, São Paulo: Atlas, 1997.

TZIRULNIK, Ernesto. O Futuro do Seguro de Responsabilidade Civil, in Doutrinas Essenciais - Responsabilidade Civil: Direito das Obrigações e Direito Negocial (org. Nelson Nery Junior e Rosa Maria de Andrade Nery), $2^{a}$ ed., São Paulo: Revista dos Tribunais, 2010.

, CAVAlCANTI, Flávio de Queiroz B., PIMENTEL, Ayrton. O contrato de seguro de acordo com o novo código civil brasileiro, $2^{\mathrm{a}}$ ed., São Paulo: Revista dos Tribunais, 2003. 
; OCTAVIANI, Alessandro. Seguro e Fraude - As Provas. Artigo para o Instituto Brasileiro de Direito de Seguros. Disponível em <http://www.ibds.com.br/artigos/SeguroEFraude-AsProvas.pdf>. Acesso em 15.10.2012.

VAMPEL, Daniella. Melhor Prevenir, in Revista Capital Aberto, nº 9, ano 1,2004.

VASCONCELOS, Pedro Pais de. D\&O INSURANCE: O Seguro de Responsabilidade Civil dos Administradores e outros Dirigentes da Sociedade Anónima, Almedina, 2007.

VENOSA, Silvio de Salvo. Direito Civil: contratos em espécie, São Paulo: Atlas, 2009. Direito Civil - Responsabilidade Civil, 4ª ed., São Paulo: Atlas, 2004.

VIVANTE, Cesare. Contrato di assicurazione, Torino: Unione Tipografica Editrice Torinese, 1909.

WALD, Arnoldo. Interesses societários e extra-societários na administração das sociedades anônimas: a perspectiva brasileira, in Revista de Direito Mercantil, $\mathrm{n}^{\circ}$ 55, jun/set 1984.

, Arnoldo. Obrigações e contratos, 16ª ed., São Paulo: Saraiva, 2004.

WELLISCH, Julya S. M., SANTOS, Alexandre P. O termo de compromisso no âmbito do mercado de valores mobiliários, in Revista de Interesse Público, Belo Horizonte: v.10, $\mathrm{n}^{\mathrm{o}} 53,2008$.

WETERINGS, Wim. Directors' \& Officers' liability, D\&O insurance and moral hazard: more control of moral hazard by $D \& O$ insurers needed to increase the incentives of directors and supervisory board members. 2012, Disponível em $<$ http://ssrn.com/abstract=2153129>. Acesso em 15.10.2012.

YOUNGMAN, Ian. Directors' and Officers' Liability Insurance., 2a ed., Inglaterra: Woodhead Publishing Limited, 1999. 


\begin{abstract}
ANEXO I
Parecer da Procuradoria de Assuntos Societários e Regimes Especiais da Superintendência de Seguros Privados
\end{abstract}




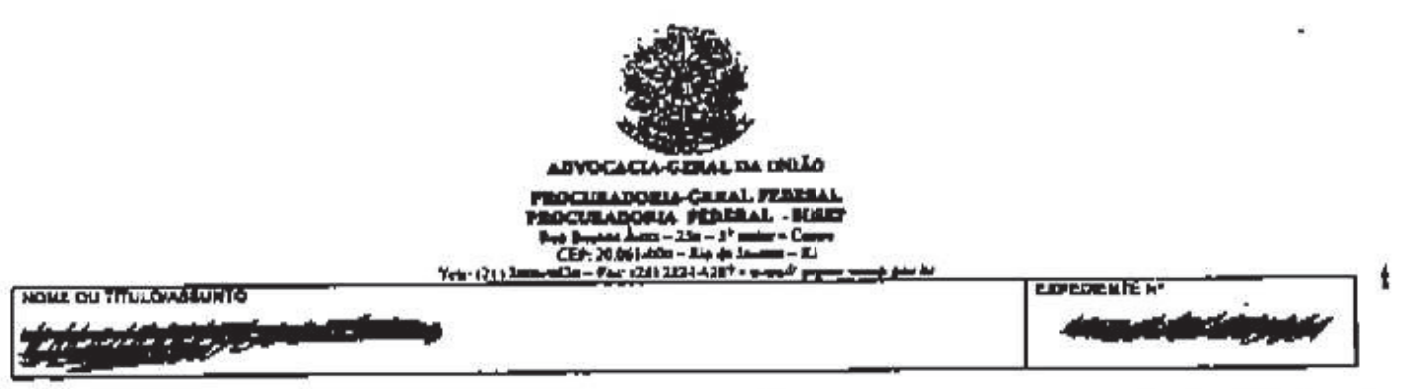

PARECER/PRGER/ASSUNTOS SOCIETÁRIOS E REG.ESPECIAIS N

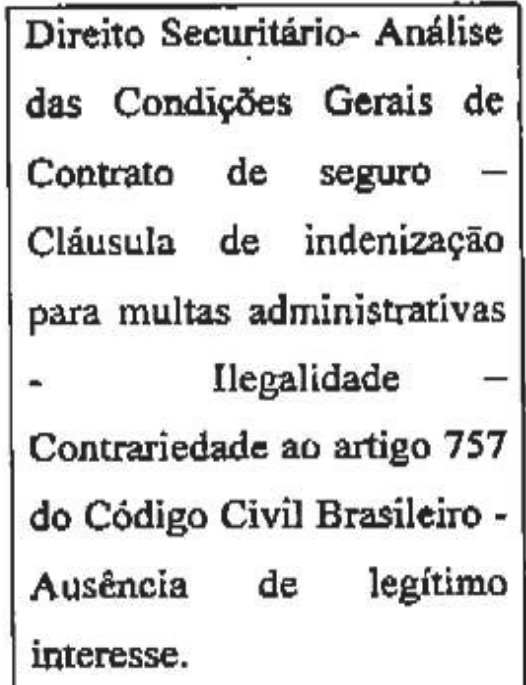

Sr. Procurador Chefe,

\section{RELATório}

1. Trata-se de encaminhamento para análise do novo seguro de Riscos Diversos "Seguro de Custas Judiciais, Honorários Advocatícios e Multas Despendidas por Administradores de Entidade Fechadas de Previdência Complementar".

2. Consta em folhas $02 / 18$, as Condiçōes Gerais e a Nota Tćcnica Atuarial do referido seguro que foram encaminhadas a SUSEP para análise e apreciaçảo.

3. Parecer técnico de fl. $24 / 25$, informa que há dúvidas quanto à viabilidade juridica do seguro proposto e propōe o envio do 


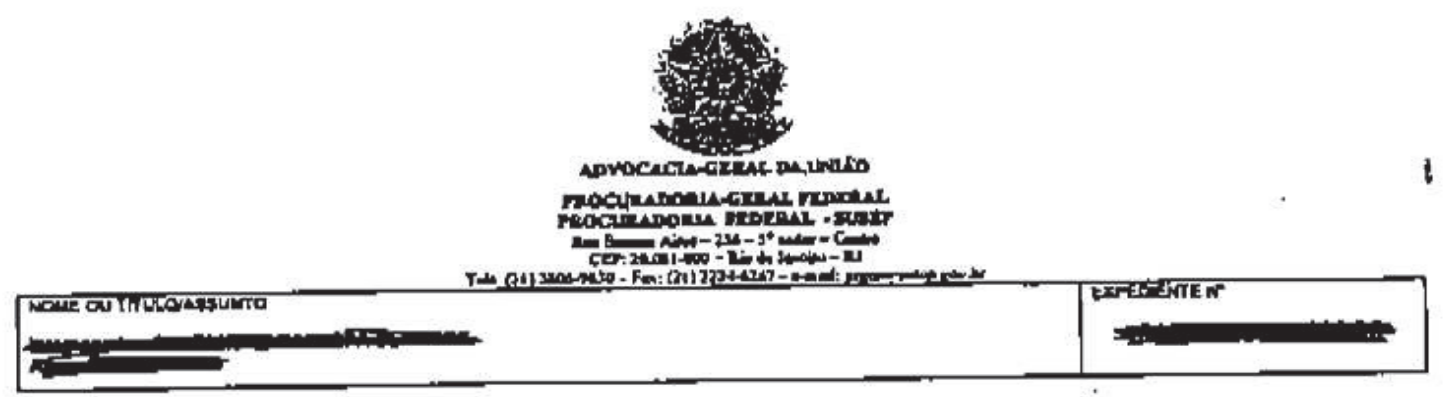

processo à Procuradoria Geral para a avaliação, principalmente em relação ao item 2, Objetivo do Seguro, e ao item 3.2, Garantia de Multas, que se confrontam com o artigo 22 da Resolução CGPC n'13/04.

4. Vêm os autos a este Procurador Federal para análise, pelo despacho de fl.25.A

5. A requerente, faz juntar aos autos, um arrazoado, justificando a necessidade do produto, bem como afirmando sua legalidade.

É o relatório, agora passo a opïnar,

\section{DO MÉRITO}

6. Resumidamente, a outorgante afima que nåo há empecilhos para que sejam assegurados interesses relativos a sanç̋es, desde que essas nảo provenham de ato doloso daqueles sujeitos especificados na norma.

7. Afirma ajnda, não haver diferença entre sançôes civis, administrativas e penais, ficando a diferença na intensidade danosa da infraçāo.Sendo assim, as penalidades administrativas poderiam ser transferidas, caso haja previsão legal.

8. Afirma a Cia " .o seguro em tela, o que se visa é garantir os interessados que sofreram imposiçø̄es por critérios objetivos ou subjetivos, porém năo criminais, ou, em qualquer outro caso, por infrações não advindas de prátiça de tos dolosos, ainda que não tipificados pela lei penal."

9. Nota-se quc o produto em questão é mais abrangente na cobertura que o próprio arrazoado da requerente entende como interesse legitimo, já que, nđo restringe a cobertura a ilicitos dolosos.

10. Além dos argumentos jurídicos que serão analisados adiante, há o argumento econômico de que com o seguro seria impossivel retirar do infrator a utilidade de conduta infracional, o que 


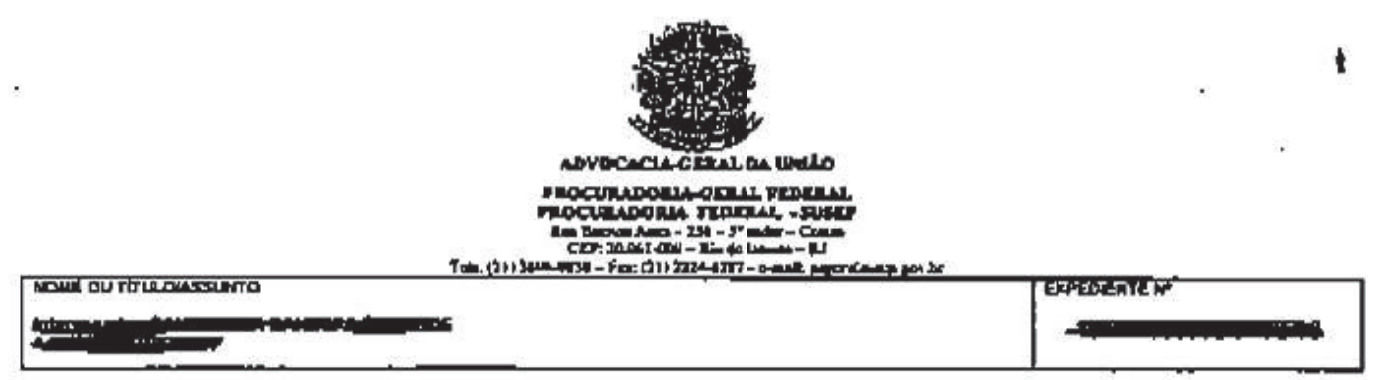

consiste na finalidade do ato progressivo promovendo entăo a lesăo a ordem publica.

11. Passa-se a analisar observando-se a legislaçăo federal regente a espécie, bem como o entendimento doutrinário acerca do assunto.

12. Inicialmente, vale ressaltar que o objetivo do referido seguro, principalmente em relaçăo à garantia contra multas, contraria o artigo $22^{1}$ da Resolução CGPC n¹3/04.

13. O Conselho de Gestão de Previdência Complementar (CGPC) é um órgão colegiado que integra a estrutura do Ministério da Previdência Social e cuja competência é regular, normatizar e coordenar as atividades das Entidades Fechadas de Previdência Complementar (fundos de pcnsăo). Também cabe ao CGPC julgar, em última instância, os recursos interpostos contra as decisőes da Secretaria de Previdência Complementar.

14. As atribuiçoes desse Conselho săo conferidas pelod artigos $5^{\circ}$ e 74 da lei complementar $n^{\circ} 109$, de 29 de meio de 2001 e o artigo $1^{\circ}$ do decreto $n^{\circ} 4.678$ de 24 de abril de 2003.

15. Ora, como a Resoluçăo citada provem desse Conselho, possui força coercitiva, sendo necessária o respeito as suas disposiçס̄es.

16. Dessa forma, é de fácil compreensão, que tal seguro não é compativel com as normas regentes, não podendo ser sua aprovaça aceita.

17. As regras na esfera jurídica forami criadas para manter a ordem, a paz e evitar injustiças. Assim, a aprovaçăo de tal seguro que em uma de suas clausulas prevê garantia contra multas, vai muito além do confronto com a Resolução citada; fere principios, desestimula a nâo adequaçāo à lei e assim por diante

\footnotetext{
' Art. 22. É vedada a contrataşa de sesura para cobertura de responsabilidade civil, penal ou administrativa de dirigentes, ex-dirigentes, empregados ou ex-erapregados da EFPC, seja por contratacia dirats ou por meio da patrocinadora, cujo pretmio implique qualquer önus finariceiro, dircto ou indireto, para a entidade fechada de previdincia complementar ou pars os planos de beneficios por ele operados.
} 


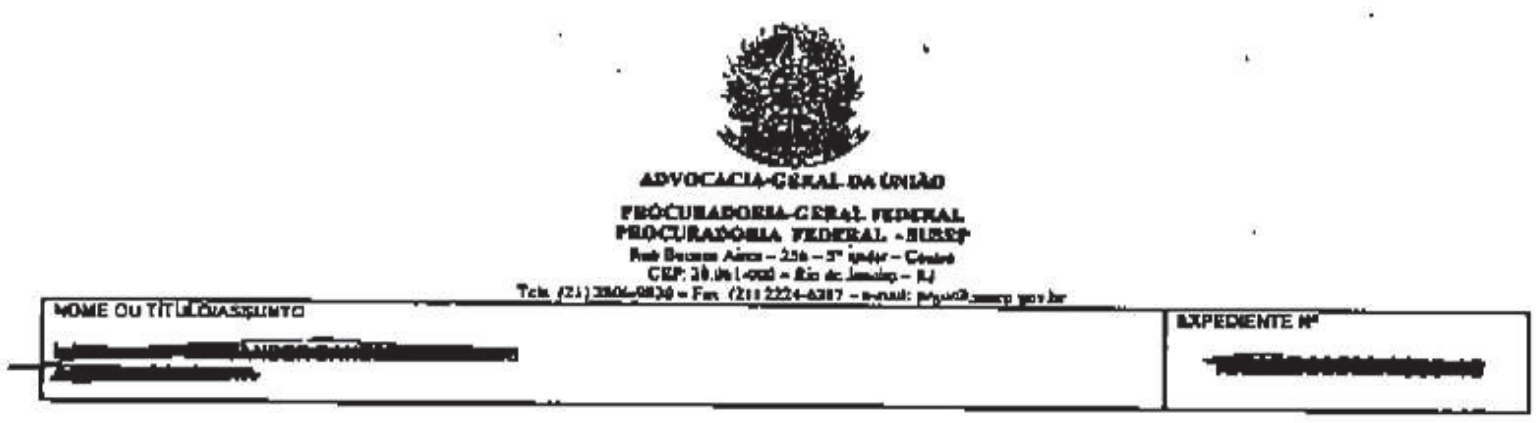

18. A pena pecuniária tem como objetivo a prevençāo da açăo ilícita, punindo aquele que a cometeu.

19. Mais do que seu caráter jurídico, o de punir o infrator, o caráter econômico é o que merece mais atençāo.

20. Esse caráter visa uma prevenção atrayés șanção econômica, evitando o cometimento da ilicitude com ameaça desse tipo de sanção.

21. A aprovação do seguro em epigrafe, deixa imune o infrator, sendo ele, futuramente reembolsado pelo valor pago.

22. Dessa forma, haverá um desestimulo ao não respeito as leis, o que é impratícável.

23. Cabe ainda salientar que a multa pode estar, muita vezes, em desproporçăo com o dano ocorrido, sendo mais benéfico ap segurador receber a multa do que arcar com as conseqüências de seu ato injusto.

24. Assin, percebe-se que tal seguro irá gerar consequiências danosas tanto para o mercado, quanto para sociedade e incentivará, mesmo que de forma indireta, o não cumprimento das leis. Essas que visam a administrar de forma mais justa possível a vida em conjunto.

25. Além disso, esse seguro é contrário ao artigo $757^{2}$ do Código Civil Brasileiro, devido a falta interesse legitimo do segurado.

26. Em relação ao interesse legitimo, Voltaire Marensi explica que "o legislador, quando substituiu a expressão "prejuizo resultante de riscos futuros", por garantia de interesse legítimo, plasmando, dessarte, no contrato de seguro uma relação licita. Em outras palavras, relaçāo de um interesse legitimo, licito e, sobretudo, estribado em principios éticos inerentes a toda a norma juridica em que há a eterna busca de uma harmonização social."

27. Nota-se que o interesse legitimo é elemento essencial no contrato de seguro e é algo que não ocorre no seguro acima citadq

\footnotetext{
${ }^{2}$ Atr. 757. Pelo contrato de seguro, o segurviker sce obriga, medisuts o pugantento do prémie, a garantir

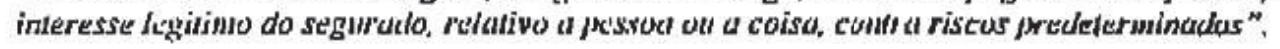




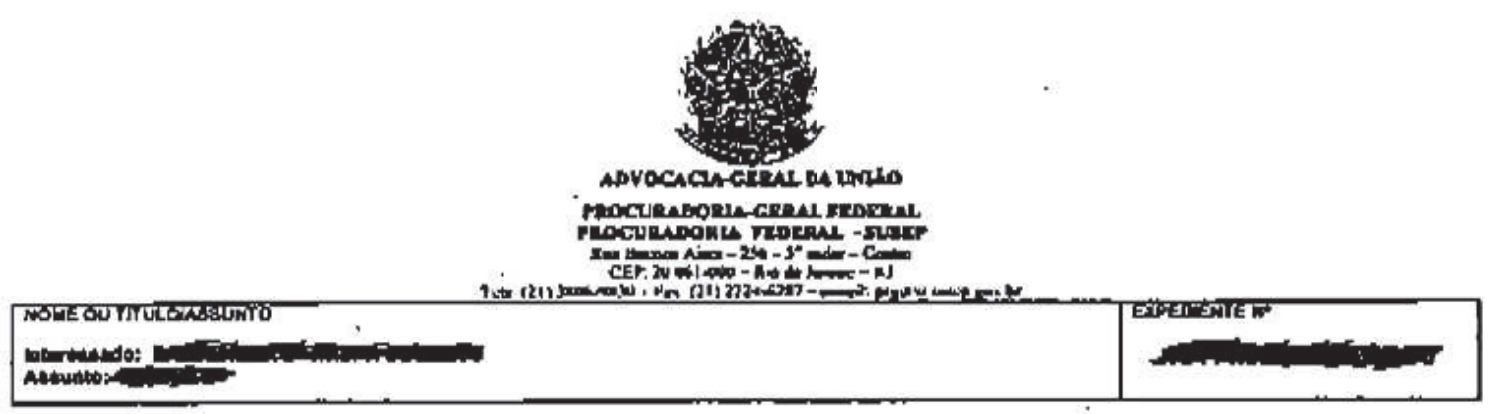

28. Desta forma, em conclusão, o contrato de seguro em questāo nāo pode ser comercializado faltando-lhe requisito essencial, qual seja, o interesse legitimo.

29. É o que me parece, salvo melhor juízo.

30. Ȧ sua douta revisăo.

PAULO ANTONIO COSTA DE ALMEIDA PENIDO Procurador Coordenador de Assuntos Societários e Regimes Especiais

Rio de janeiro, 29 de nồembro de 2006
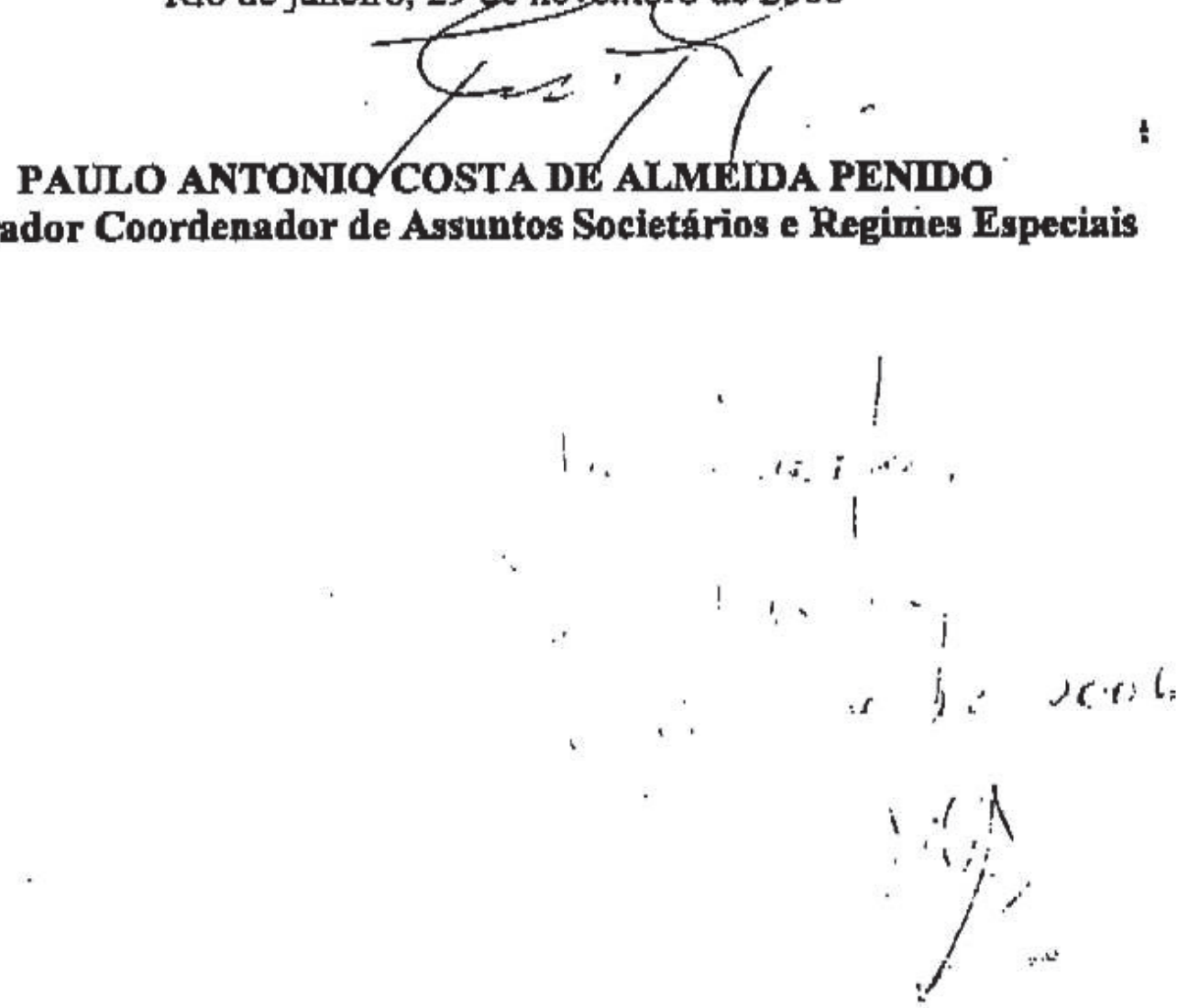